

\section{STRUKTURĒTAS ZIVJU MASAS UN TO PRODUKTU RAŽOŠANAS \\ ROKASGRĀMATA}

Ražošanas tehnoloǵija Ekonomiskie aprēkini

Jelgava, 2021 g. 
LATVIJAS LAUKSAIMNIECĪBAS UNIVERSITĀTE

PĀRTIKAS TEHNOLOGIIAS FAKULTĀTE

Rokasgrāmatas veidošanai izmantoti ElZF1 projekta "Strukturētas zivju masas (farša) ražošana no Baltijas jūras zivīm (renǵes un brētlinas) un tā izmantošana zivju produktos» (Nr. 16-0F01101-000005) atskaites eḱksperimentālie un pētījumos iegūtie rezultāti.

Materiāla citēšanas gadījumā atsauce obligāta, bet pārpublicēšanas gadījumā nepieciešama atlauja

Autoru kolektīvs: M.Šabovics, S.Muižniece-Brasava, I.Grāmatin,a, S.Sazonova, T.Kince, J.Zagorska, E.Straumīte, Z.Krūma, D.Kunkulberga, E.Sturmoviča, M.Šilovs, J.Ozolinš

Vāka autors: Mārtiṇ̌s Šabovics

Rokasgrāmatā ieklautie attēli / diagrammas ir autoru veidoti

C) 2020 Latvijas Lauksaimniecības universitāte

Sadarbībā ar FoodTech Baltija SIA

ISBN 978-9984-48-371-9

Zivju pārstrādes nozarē nepilnīgas izejvielu izmantošanas problēma ir īpaši aktuāla, jo tā veido ievērojami lielu procentuālo dalu no zivju pārstrādes ražošanas procesa. Pievienotā vērtība, kas tiks iegūta risinot šo problēmu, ir pievilcīga alternatīva ne tikai tāpēc, ka rada papildu ekonomiskus stimulus ražotājam, bet arī atbilst zilās ekonomikas principiem un nodrošina ilgtspēju un atbildīgu attieksmi pret resursiem.

Rokasgrāmatas saturā tiek aprakstīti uzturā izmantojamās brētliṇu maltās galas un to atbilstošu galaproduktu ražošanas tehnoloǵiskie procesi un tehnoloǵiskās ipašības. Tà pat tiek izvērtēts ekonomiskais pamatojums brētliṇu maltās galalas produktu ražošanai.

Rokasgrāmata paredzēta pārtikas nozares bakalaura, maǵistrantūras, doktorantūras programmu studentiem, zivju pārstrādes nozares zinātniekiem, ka arī nozares speciālistiem, pārtikas tehnologiem.

Projekts „Strukturētas zivju masas (farša) ražošana no Baltijas jūras zivīm (renǵes un brētliṇas) un tā izmantošana zivju produktos» (Nr. 16-0F01101-000005) îstenots ar Lauku atbalsta dienesta un Eiropas Jūrlietu un attīstības fonda atbalstu.

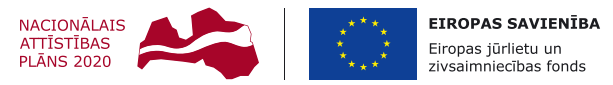

levads

1. Zivju maltās galas pagatavošanai paredzēto mazizmēra izejvielu raksturojums

2. Uzturā izmantojamās zivju maltās galas ražošanas tehnoloǵiskie procesi

3. Zivju maltās galas tehnoloǵiskās īpašîbas

4. No mazizmēra zivīm izgatavotas maltās gaḷas stabilizācija ......... 27

5. Brētliṇu bāzes maltās galas ražošanas process 31

6. Zivju maltās gaḷas produkcijas sortimenta ražošanas shēma ..... 35

7. Gatavo izstrādājumu sortiments. Saldētu, atdzesētu pusfabrikātu, zivju desu, produktu ar pildijumu un zivju miltu izstrādājumu ražošanas īpatnības. Zivju maltās galas uzkodas un perspektīvie produkti

8. No brētlinām izgatavotas maltās galas produktu ražošanas ekonomika un organizācija

Izmantoto avotu saraksts 
_ai paaugstinātu Baltijas jūras zivju resursu izmantošanas efektivitāti, palielinātu sortimentu un pagarinātu patērētājiem piedāvāto zivju produktu derīguma termiṇu, pasaules zivju pārstrādes rūpniecības nozare ir apguvusi zivju maltās galas, kas kalpo kā pusfabrikāts dažādu kulinārijas izstrādājumu (pastēšu, desu, cīsiṇu, kotlešu, pelmen,u u.c.) izgatavošanai, ražošanu. Malto galı parasti gatavo no lielajām zivīm - mintajiem, hekiem, vēdzelēm, marlīnēm, pristipomām, mencām, forelēm, stavridām, plekstēm, jūras asariem, tunzivīm u.c.

Latvijas zvejniekiem ir loti svarīgi maksimālà apjomā realizēt mazizmēra zivis - brētlinas, renǵes, un novirzît papildu izejvielu apjomus pārtikas produktu izstrādei, nevis izmantot tās kā dzīvnieku barību. Tomēr jāatzīmēe, ka rūpnieciski pārstrādājot maza izmēra zivis maltajā gạ̄ā, nākas saskarties ar vērā n,emamām problēmām. lepriekšminētais ir saistīts ar šo zivju biokīmiskajām īpatnībām, kā arī ar to, ka pašlaik nav pieejami tehnoloǵisko procesu risinājumi šo zivju pārstrādei maltajā gậā.

Sasmalcinātas maltās gaḷas produktu galvenā atškirīiba no produktiem, kas izgatavoti no dabiskiem, veseliem zivju liemeniem, ir sākotnējo izejvielu pilnīga izmantošana. Lai ražotu patērētājiem pieejamus augstas kvalitātes produktus - zivju steikus, medaljonus vai filejas, tiek izmantota tikai neliela zivs dala (muskulaudi). Turklāt zivju produktu ražotājam pāri paliek atlikumi ar zemu enerǵétisko vērtību un uzturvērtību, pēc kuriem pārtikas produktu tirgū nav pieprasijuma. Ražošanā šādu blakusproduktu (atlikumproduktu) utilizācija parasti saistîta ar papildu izmaksām un ir problemātiska.

Uzturā izmantojamās daḷas kopējais daudzums ir svarīgākais zivju apstrādes paṇēmiena efektivitātes izvērtēšanas kritērijs. Zivju filetēšanas rezultātā uzturā izmantojamās daḷas apjoms vidēji ir 28-33\%, savukārt, pārstrādājot zivis maltajā gạă, tas sasniedz pat 60\%. Tādā veidā maltās galas iegūšanas tehnoloǵijas lauj pilnīgāk izmantot zivju izejvielas un piedāvāt patērētājiem produktu, kam piemīt augsta funkcionalitāte un uzturvērtîba.

Maltās galas ražošanas no mazizmēra zivīm procesa pamatā ir sarežǵítu moderno augsta ražǐguma bezatlikumu aprīkojuma izmantošana, kas likvidē mazkvalificēta darbaspēka nepieciešamību un nodrošina ražošanas procesu automatizāciju.

Šajā rokasgrāmatā izklāstīti Latvijas Lauksaimniecības universitātes Pārtikas tehnoloǵijas un Ekonomikas fakultātēs 2017. - 2018. gadā veiktā pētijuma „Strukturētas zivju masas (farša) ražošana no Baltijas jūras zivīm un tā izmantošana zivju produktos» (projekta numurs Nr.16-00-F01101-000005) rezultāti. Pétījumā veikta kompleksa problēmu izpēte un analīze, kas saistīta ar maltās galıs ražošanu no Baltijas jūrā sastopamajām mazizmēra zivīm. Projekta mērkis atbilst Latvijas Nacionālā attīstības plāna 2014. - 2020. gadam rīcības virziena „Attīstìtā pētniecība, inovācija un augstākā izglitība» 2. mērkim, kas ir vērsts uz inovatīvu, starptautiski konkurētspējīgu produktu ar augstu pievienoto vērtību radī̌anas veicināšanu.

Rokasgrāmatā tiek izskatītas izejvielu īpatnības, maltās gaḷas izstrādes no mazizmēra zivīm ražošanas tehnoloǵiskā procesa îpatnības, maltās gạlas struktūras, tās stabilizācijas jautājumi, izmantojot dažādas piedevas.

Papildus aplūkoti brētliṇu maltās gạlas un atbilstošu galaproduktu ražošanas tehnoloǵiskie procesi, aprakstīts nepieciešamais tehnoloǵiskais aprīkojums, sniegti izstrādāto zivju produktu recepšu piemēri, uzskaitītas kvalitātes, uzglabāšanas termiṇu un darbinieku kvalifikācijas prasibas.

Rokasgrāmata būs noderīga studentiem, zivju pārstrādes nozares zinātniskajiem un praktiskajiem darbiniekiem, tā arī palìdzēs paplašināt Latvijas uzṇēmumos ražoto zivju produktu sortimentu. 


\section{ZIVJU MALTĀS GALAS \\ PAGATAVOŠANAI PAREDZËTO MAZIZMËRA IZEJVIELU RAKSTUROJUMS}

7 iek

iek izskatīti trīs zivju izejvielu resursi: brētlinas, renǵes un šo divu zivju maisijums. Nemot vērā to, ka brētlinas un renǵes ienem vienu un to pašu ekoloǵisko nišu, vairumā gadījumu nav iespējams nodrošināt tīru tikai vienas sugas zivju nozveju, tajā noteikti būs lielāka vai mazāka otras zivju sugas piejaukuma dala. Taču maltās galas ražošanas procesā zivju škirošana nav nepieciešama.

Brētlinas un renǵes tiek zvejotas visu gadu, taču vasarā nozvejotās zivis nav derīgas tradicionālai pārstrādei (sālišanai un konservēšanai), jo zivju kermenī ir liels daudzums airkājvēžu (1. att.). Calanus ir kopējais zooplanktona, airkājvēžu vēžveidīgo dzimtas nosaukums. Calanus nav parazìts, kā, piemēram, Opisthorchiasis vai nematodes, bet gan specifiska zivju barība, kas vasaras laikā attīstās tādos daudzumos, ka spēj mainīt zivju izejvielu tehnoloǵiskos parametrus: sturktūru un izejvielu reoloǵiskās īpašības.

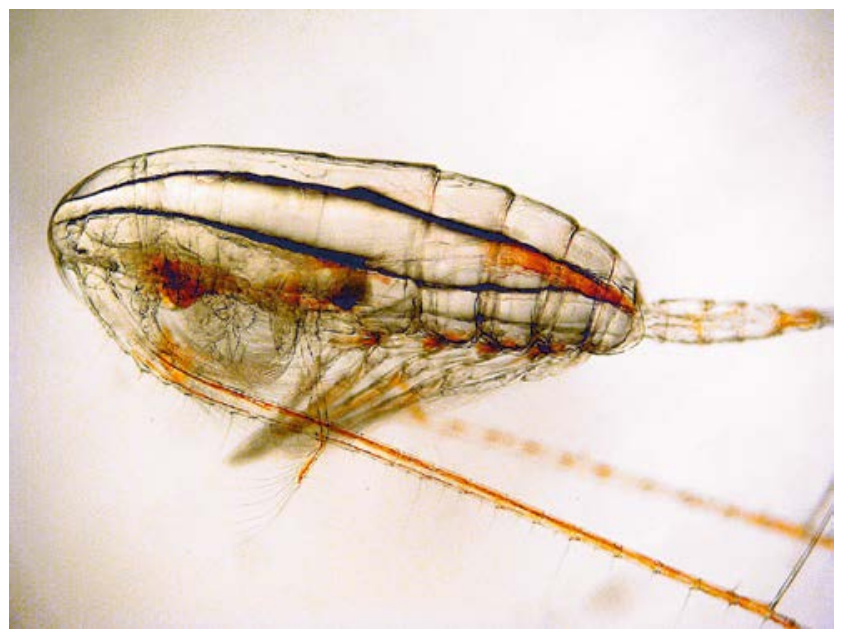

1. attēls. Calanus airkājvēzis
Taču, pārstrādājot brētlinas un renǵes maltajā galā, Calanus klātbūtne nerada būtiskas problēmas ražošanas procesa laikā. Zivju, kas ir sasaldētas kopā ar Calanus, kvalitāte fermentu darbības rezultātā nemainās, un tās pilnībā saglabā savu uzturvērtību. Jāatzīmēe, ka bieži vien zivju uzturvērtîba pat pieaug, jo Calanus ir bagāti ar taukiem un olbaltumvielām. Tomēr lielāka uzmanība ir jāpievērš vairăk izmantotajai izejvielai, kura tiek lietota maltās masas ražošanai un no kuras iespējams izstrādāt dažāda veida galaproduktus.

\subsection{BALTIJAS BRËTLIN,A SPRATTUS SPRATTUS}

Brētlina ir neliela izmēra, sudrabainas nokrāsas, baros dzīvojoša pelaǵiskā zivs, kas pieder sillku dzimtai (2. att.). Uz zivs vēdera ir dzelonainas zvīnas, kuru dēl lielà dzilumā zivs klūst nemanāma. Šìs zvīnas ir veidotas kā savdabīgs kịlis, pateicoties kuram zivs ieguvusi savu nosaukumu (brētlinas mēdz saukt arī par kilavām). Pie brētliñām pieskaitāmas Eiropas, Baltijas, Kaspijas, Azova-Melnās jūras, Arābu jūras, Melnās jūras un lielacu brētlinas. Lielos daudzumos tās sastopamas Melnajā, Baltijas, Norvēǵijas jūrāa, Vidusjūrā un Ziemeḷ jūrā. Ar brētliṇu apstrādi nodarbojas galvenokārt Latvija, Norvēǵija, Krievija, Bulgārija, Dānija un Ukraina.

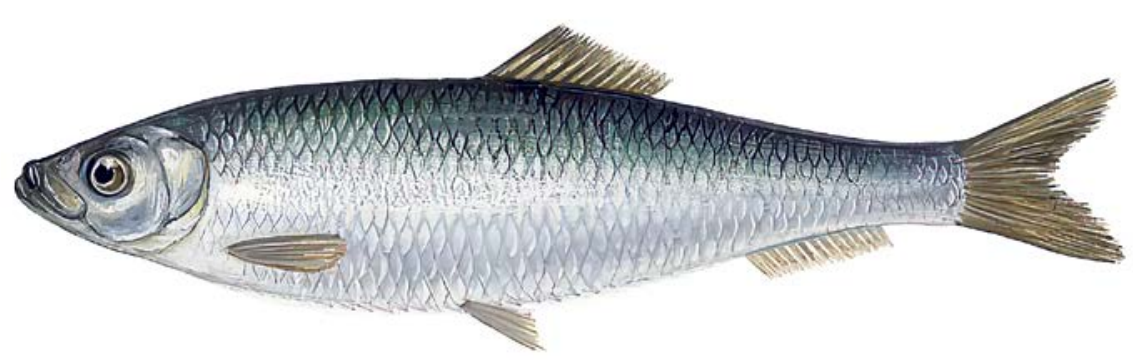

2. attēls. Baltijas brētlina Sprattus sprattus

Brētlinas satur daudz polinepiesātinātās taukskābes, kurām pastāv pretaterosklerotiska iedarbība cilvēka organismā - tās samazina kaitīgo lipoproteīdu un zema blīvuma triglecirīdu līmeni. Pareizi pagatavotas, brētliṇas ir ieteicamas cilvēkiem ar sirds asinsvadu slimībām. Brētliṇu augsto uzturvērtību nosaka arī augstais kalcija daudzums, kas 

kā arī minerālvielas: fluors, niḳelis, cinks, kālijs, magnijs, hlors, dzelzs, cinks, molibdēns. Sezonālas brētliṇu garuma un svara izmainas netiek novērotas. Piekrastes tuvumā nozvejoto brētliṇu vidējais garums sastāda 11 - 12 cm, bet vidējais svars - apmēram 10 g. Atklātā jūrā nozvejotās brētlinas ir nedaudz smagākas - vidēji $15 \mathrm{~g}$.

Tāpat arī būtiski nemainās brētliṇu vidējais svars pavasara - vasaras un rudens - ziemas nozvejas periodā. Liemenis ar iekšejiem orgāniem sastāda vidēji 84,1\% no veselas zivs svara, galva - 13,2\%, astes spura - 0,6\%, iekšejie orgāni (bez dzimumorgāniem) - 4,5\%, dzimumorgāni - 2,1\%.

1. tabula. Baltijas brētlinu uzturvērtība

\begin{tabular}{||c|c||}
\hline \hline Sastāvs & Masa, g/100 g \\
\hline Ūdens & 72 \\
\hline Olbaltumvielas & 17,1 \\
\hline Enerǵétiskā vērtība & 136,8 \\
\hline No lipīdiem iegūtās kalorijas & 68,4 \\
\hline Tauki kopā & 7,6 \\
\hline Polinepiesātinātie tauki & 2,9 \\
\hline Holesterīns & 0,084 \\
\hline Pelni & 14,3 \\
\hline Nātrijs & 4,917 \\
\hline Kālijs & 0,187 \\
\hline Dzelzs & 0,04 \\
\hline Kalcijs & 0,12 \\
\hline Magnijs & 0,26 \\
\hline Fosfors & 0,084 \\
\hline Cinks & 0,006 \\
\hline
\end{tabular}

\subsection{RENGE (BALTIJAS SILLKE) \\ CLUPEA HARENGUS MEMBRAS}

Ren,ǵes ir sīkas, pelaǵiskas, sillkveidīgo zivju kārtas zivis (3.att.). Renǵes dzīvo Baltijas jūras ūden,os à samazinātu sālumu, un tàs sauc par Baltijas sillkēm.

Renǵu dzives cikls vidēji ilgst 6 - 7 gadus. Renǵges ir tipiskas pelaǵiskas zivis, kas dzīvo üdens masīvā un barojas ar zooplanktonu, galvenokārt ar sīkiem vēžveidīgajiem, kā arī ar kāpuriem vai citu zivju mazuliem.

Ren,ǵes dzĩvo Baltijas jūrā uz austrumiem no Dāṇu šauruma, kā jau minēts iepriekšs, tās mît ūdenī ar pazeminātu sālumú, dažreiz sastopamas arī Zviedrijas saldūdens ezeros.

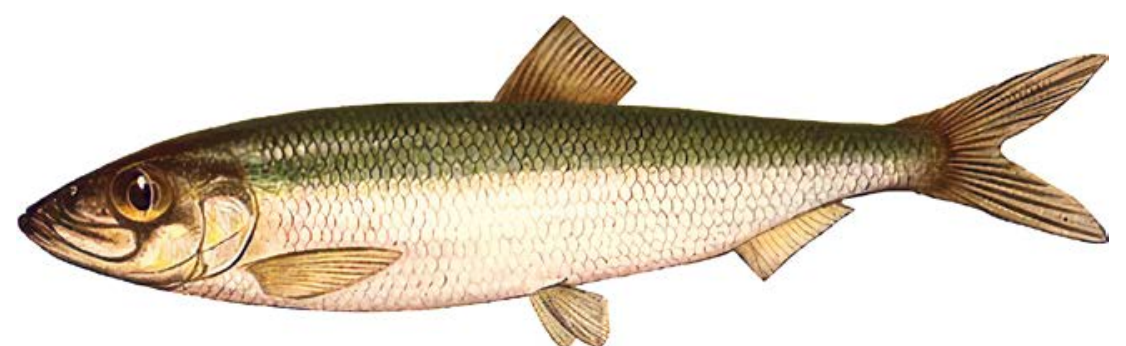

3. attēls. Renǵe (Baltijas sillke) Clupea harengus membra

Liepājas piekrastes renǵes ir lielākas par pārējo Baltijas jūras rajonu renǵēm. Rīgas līča renǵes ir sīkākas par atklātos jūras rajonos dzīvojošām rengéēm, taču lielākas par Kolkas rajona ren,ǵēm. Novērojumi par dažāda lieluma renǵu attiecību lomā uzskatāmi parāda, ka renǵu garums un svars sezonāli mainās, turklāt zivju izmērs samazinās laika periodā no pavasara līdz rudenim. Renǵu svara salīdzinājums pavasara un rudens periodos uzrādija liemeṇa (bez iekšèjiem orgāniem) relatīvā svara pieaugumu rudens periodā. Visos nozvejas rajonos liemenis bez iekšējiem orgāniem pavasari vidēji veido 61,6\%, bet rudenī 68,9\% no veselas zivs svara; galva - pavasarī 18,1\%, bet rudenī-16,7\%; dzimumorgāni - pavasarī 14\%, turpretim rudenī 2,7\%; iekšējie orgāni (bez dzimumorgāniem) - pavasarī 3,6\%, bet rudenī 5,1\%; astes spura gan pavasarī, gan rudenī- 0,8\%.

Tāpat, kā jebkuras citas zivis, arī renǵes satur neaizvietojamās aminoskābes un Omega 3 taukskābes, kas pazemina holesterīna 
saturu asinīs, novēršot aterosklerotisku izmainu parādīšanos asinsvados. Ren,ǵēs esošās Omega-3 taukskābes ir lielisks antioksidants, kas stiprina imunitāti. Renǵes satur arī lielu daudzumu vitamīnu (A, D, B1, B2, B12, C, E, PP), kā arī mikro- un makroelementus: magniju (20 mg), kalciju (20 mg), nātriju (70 mg), fosforu (220 mg), kāliju (210 mg) sēru (150 mg), hloru (165 mg), cinku (1,35 mg), dzelzi (1 mg), jodu

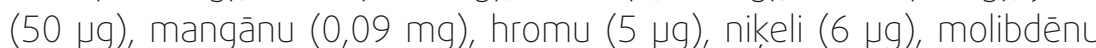
(4 Ng). Renǵes ir produkts, kas atšk̦iras ar paaugstinātu fluora (430 $\mu g)$, vara $(160 \mu g)$ un kobalta $(250 \mu g)$ saturu.

2. tabula. Renǵu uzturvērtība

\begin{tabular}{||c|c||}
\hline Sastāvs & Masa, g/100 g \\
\hline Olbaltumvielas & 17,0 \\
\hline Neaizvietojamās aminoskābes & 9,96 \\
\hline Aizvietojamās aminoskābes & 9,35 \\
\hline Enerǵētiskā vērtība & $97-143$ (atkarībā no sezonas) \\
\hline Kopā tauki & 6,3 \\
\hline Piesātinātās taukskābes & 2,0 \\
\hline Polinepiesātinātās taukskābes & 1,14 \\
\hline Mononepiesātinātās taukskābes & 2,0 \\
\hline Holesterīns & 0,08 \\
\hline Nātrijs & 0,07 \\
\hline Kālijs & 0,210 \\
\hline Dzelzss & 0,01 \\
\hline Kalcijs & 0,02 \\
\hline Magnnijs & 0,20 \\
\hline Fosfors & 0,11 \\
\hline \hline
\end{tabular}

\subsection{ZIVJU MALTĀS GALAS KVALITĀTES ATKARĪBA NO DAŽĀDIEM FAKTORIEM}

Galvenais un būtiskākais faktors, kas ietekmē jebkura veida zivju produkcijas kvalitāti un drošību, ir uzṇēmumā ienākošo, turpmākai pārstrādei paredzēto zivju izejvielu stāvoklis.

Mūsdienās lietotā pārtikas kīmija var ietekmēt daudzus gatavo zivju produktu tehnoloǵiskos parametrus: organoleptiskos un reoloǵiskos rādītājus, uzglabāšanas termiṇus un ražošanas ekonomisko efektivitāti. Taču, ja ražošanas uznẹmumā tiek pienemtas zemas kvalitātes izejvielas, visi šie iepriekš nosauktie pozitîvie aspekti nedarbojas, jo pārtikas piedevas var izmainit izejvielu ippašības nevis uzlabot to kvalitāti.

Pie galvenajiem faktoriem, kas ietekmē un nosaka zivju izmantošanas iespējas maltās gạlas ražošanai, pieskaitāmi sekojoši rāditāji: zivju izejvielu pirms to pārstrādes maltajā galā uzglabāšanas panēmiens un ilgums; muskuḷaudu kīmiskais sastāvs, jo īpaši tādu vielu klātbūtne, kas katalizē nevēlamas izmainas maltajā galạ̄; primārās apstrādes kvalitāte un rūpīgums; zivju morfoloǵiskās uzbūves īpatnības, kas ir saistītas ar to turpmāko pielietojumu primārai mehāniskajai apstrādei; parazîtu klātbūtne u.c.

Veicot zivju pēcnāves stāvokla ietekmes izpēti, tika noskaidrots, ka, jo îsāku laiku zivis ir uzglabātas pēc nozvejas, jo augstāka ir zivju maltās galas kvalitāte. Maltās galas masas ūdens saistǐšanas un noturēšanas spējas bija augstākas, ja zivis, kas tika pārstrādātas, atradās pēcnāves sastinguma vai nobriešanas procesa sākumstadijā.

Ražojot malto galı, vidēji treknu zivju pielietošanas iespējas turpmākai pārstrādei galvenokārt tiek noteiktas, nemot vērā lipīdu oksidācijas pakāpi

Maltās galas masas ražošanai zivju pārstrādes uzṇēmumos tiek pienemtas svaigas (dzīvas vai lĩdz 12 stundas pēc asfiksijas), atdzesètas vai saldētas zivis.

Dzīvu zivju kvalitāti raksturo to kopējais stāvoklis - zivīm ir jābūt bez ārējiem bojājumiem un redzamām saslimšanu pazīmēm, ar dabisku nokrāsu. Dzīvas zivis pārvadā nehlorētā ūdenī pie temperatūras, 
kas nepārsniedz $12{ }^{\circ} \mathrm{C}$. Pielaujama dzīvu zivju pārvadāšana mitrā gaisā (relatīvais mitrums $95 \pm 5 \%$, temperatūra $1-4^{\circ} \mathrm{C}$ ).

Atdzesētu zivju temperatūra muskulaudu vidusdalā pie mugurkaula ir $1-5^{\circ} \mathrm{C}$. Labas kvalitātes zivīm ir raksturīga dabiska krāsa, āda tīra, bez bojājumiem, žaunu krāsa - no tumši sarkanas līdz rozā, klātas ar staipīgu, caurspīdīgu glıtu, smarža - svaiga. Maltās galas un tās produktu ražošana no atdzesētām mazizmēra zivīm ir apgrūtināta tādēl, ka zivju iekšējos orgānos attītās autolītiskie un proteolītiskie procesi, kas izraisa nepatīkamas smaržas un garšas parādišanos, kas, savukārt, ievērojami pasliktina produktu organoleptiskos kvalitātes rādìtājus.

Saldētu zivju raksturīgā temperatūra muskulaudu vidusdaḷā ir no -16 līdz - $18{ }^{\circ} \mathrm{C}$ vai zemāka. Zivju kermenis sastāv no vidukla (lielākā dalı), galvas un spuru muskuliem. Savukārt vidukla muskulaudi sastāv no muguras un sānu muskuḷiem. Lielais sānu muskulis ir novietots gar sānu līniju. Sānu muskula krāsa ir balta, jo tā audi, atškirībā no zemādas sarkanā (tumšā) muskula, nesatur mioglobulīnu. Sarkanās gaḷs (muskuḷa) relatīvā masa ir atkarīga no zivju kustīguma pakāpes üdens vidē.

Sarkanā gaḷa ievērojami atškiras no baltās galas pēc kīmiskā sastāva un fermentatīvās aktivitātes. Baltajos muskulos metaboliskie procesi notiek anaerobos apstāklos, bet enerǵija izdalās galvenokārt glikogēna sadalīšanās rezultātā, savukārt sarkanajos muskulos galvenais enerǵijas avots ir lipīdi. Lielākajai dalai fermentu, kas atrodas sarkanajos muskulos, ir raksturīga augstāka aktivitāte, nekā baltajos muskuḷos. Tāpat sarkanajos muskulos atrodas augstāks tādu vielu saturs, kas pastiprina lipĩdu - mioglobulīna, hemoglobīna un citohroma c oksidāciju.

Zivju gală atrodas arī augsts tādu fermentu daudzums, kas izsauc tauku izmainas, uzglabājot to ledusskapī. Pie tādiem pieskaitāmas lipāzes, fosfolipāzes u.c. Audos esošie fermenti īpaši ir atbildīgi par tauku hidrolītisku sadalǐšanos zivju maltās galas masā. Lipāžu un fosfolipāžuhidrolāzes aktivitāte ir nesaraujami saistīta ar brīvā ūdens daudzumu, kas samazinās zivju saldēšanas procesa rezultātā. Taču tiešas saistības starp hidrolītiskajiem fermentiem, lipīdu sadalīšanos un maltās galas sasaldēšanas temperatūru nav, jo sasaldēšana (vai defrostācija) ievērojami paaugstina fermentu aktivitāti. Visaugstākais lipīdu hidrolìzes produktu daudzums veidojas maltajā galāa kas tiek uzglabāta temperatūras intervālā no - 5 lìdz -7 C. Pazeminoties temperatūrai, samazinās arī hidrolīzes ātrums.

Lipīdu oksidācija ir viens no galvenajiem iemesliem, kādẹ! veidojas nepatīkama saldētas maltās galas smarža, tajā skaitā arī vidēji treknām zivīm. Lai smarža ievērojami pasliktinātos, pietiek ar pavisam nenozīmīga lipīdu daudzuma oksidāciju.

Dažādas zivju sugas savā starpā atškiras galvenokārt pēc kīmiskā sastāva. Vislielākā nozīme ir tieši muskulaudos ietilpstošajām olbaltumvielām, tas ir, ūdenī škīstošajām (sarkoplazmatiskajām) un sāls šḳidumā šḳīstošajām (miofibrillārajām) olbaltumvielām. Tās veido lielāko dalı no muskulaudos esošajām olbaltumvielām, un tām ir noteikta ietekme uz maltās galas kā pusfabrikāta funkcionālajām īpašībām zivju produktu gatavošanā.

Miofibrillāro olbaltumvielu škīidības pakāpe un koncentrācija maltajā galā nosaka tās konsistencí pēc termiskās apstrādes. İpaša nozīme ir olbaltumvielu denaturācijas novēršanai uzglabāšanas laikā. Zivju ādas gabaliṇu klātbūtne maltajā galā pasliktina tās krāsu un samazina arī iespējamo uzglabāšanas laiku atdzesētā vai saldētā veidā. Zivju àdā ir glotu dziedzeri, kas izdala glikoproteīnu - mucīnu, kas, sajaucoties ar ūdeni, veido glotas. Pēc zivju nāves šì viela klūst par ideālu vidi mikroorganismu attīstībai un galveno muskulaudu infekcijas avotu.

Maltās galıs krāsas pasliktināšanās notiek galvenokārt, pateicoties krāsu saturošajām šūnām, kas atrodas epidermā vai pašā ādā.

Saldētu zivju uzglabāšanas laikā ādā esošo lipīdu oksidācijas ātrums ir ievērojami lielāks, nekā citu audu oksidēšanās ātrums. Lai stabilizētu maltās galas masā esošos lipĩdus, tiek izmantoti antioksidanti un sinerǵisti (vielas, kurām nepiemīt antioksidatīva iedarbība vai kuras ir vāji antioksidanti, bet kuras pastiprina antioksidantu darbību, parasti skābes vai kompleksa veidotāii).

Zivju malšanas procesa laikā maltajā galāa nonāk asins recekli. Sarkano asinsḳermenī̌̌u hemolīze, kas notiek zivju uzglabāšanas laikā pirms pārstrādes, maltās galas izgatavošanas un sasaldēšanas, 
izraisa hemoglobīna izdališanos un tā pāreju apkārtējā vidē (maltajā galı̄).

Vienlaikus notiek arī hemoglobīna kīmiskās izmainas, jo īpaši tā oksidēšanās (skābeklı pievienošanās) un turpmāka oksihemoglobīna veidošanās. Oksihemoglobīna klātbūtne maltajā galāa palielina tās oksidēšanās pakāpi.

Skeleta daląs, kas nonāk zivju maltajā gaḷā, satur daudz minerālvielu, ìpaši fosforu un kalciju - attiecīgi, 1,1 - 2,4\% un 1,5 - 5,7\%. Tomēr skeleta dalu satura ietekme uz maltās gaḷs kịmiskajām īpašībām ir neliela.

Zivju taukos ir maz tokoferola, kas ir to galvenais dabiskais oksidētājs. Jo treknākas zivis, jo zemāks ir tokoferola saturs tajās, kas, no tehnoloǵiskà viedokḷa, nav labvēlīgs faktors.

Audu, kas katalizē nevēlamas fizikāli kīimiskās izmainas maltajā gaḷă, klātbūtne paātrina oksidatīvos un hidrolìtiskos procesus taukos, kā arī trimetilamīna oksīda (TMAO) veidošanos un olbaltumvielu škīšanas spēju samazināšanos saldētā zivju maltajā galı̄ă.

TMAO sadalǐšanās zivju izejvielās ir viens no galvenajiem kvalitātes pasliktināšanās iemesliem. Tas īpaši attiecas uz sasmalcinātu galı, jo TMAO sadalǐšanās ātrums tajā parasti ir 2-3 reizes lielāks, nekā zivju filejā vai liemenos.

Vislielākās fizikālās un kīmiskās izmainas sasmalcinātu zivju gaḷā vērojamas sākotnējā uzglabāšanas periodā, parasti laika posmā līdz 1 mēnesim.

\section{UZTURĀ IZMANTOJAMĀS ZIVJU MALTĀS GALAS RAŽOŠANAS TEHNOLOGISKIE PROCESI}

M loǵiskās īpašỉbas, kas nosaka un paplašina tās turpmākās izmantošanas iespējas. Zivju maltā gala ir paklauta tādu faktoru iedarbībai, kas ievērojami intensificēe nevēlamas izmainas zivju izejvielās. Pie tām pieskaitāmas: gallas sākotnējās struktūras sagraušana (sasmalcinot); sasmalcinātas gallas masā ir audi, piemēram, tauki, asins, āda u.c., kas katalizē maltajā galāa notiekošos nevēlamos procesus; masas maisīšanas laikā maltajā galā nonāk arī zināms daudzums gaisa.

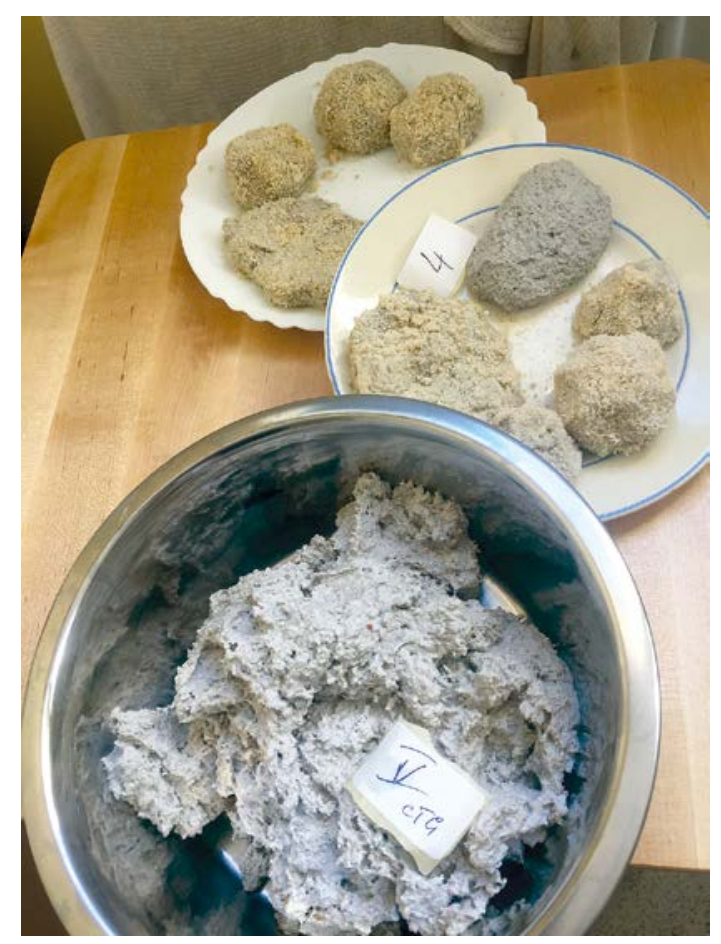

4. attēls.

Eksperimentālas zivju maltās galas izgatavošana laboratorijas apstāklıs 
Maltās galas gatavošanas panēmieni lielā mērā ietekmē tās fizikālās un kīmiskās īpašības. No tehnoloǵiskā un ekonomiskā viedokla vislielāko interesi rada maltā gala ar stabilizētu sastāvu un īpašībām, kas pēc kīmiskā sastāva un îpašībām tikai nedaudz atškiras no sasmalcinātas zivju galas.

Zivju izejvielu smalcināšanu, ražojot malto galı no mazizmēra zivīm, var realizēt divos veidos: izmantojot zivju separatoru - neopres vai kuteri.

\subsection{MALTĀS GALAS RAŽOŠANA, IZMANTOJOT GALAS-KAULU SEPARATORUS (NEOPRESES)}

Praksē zivju apstrādes uzṇēmumos maltās galas izgatavošanai no liela izmēra zivju sugu (lašu, mencu) filetēšanas atlikumiem un vidēja izmēra zivju liemen,iem (bez galvām un kidātiem) tiek plaši izmantotas neopreses (5.att).

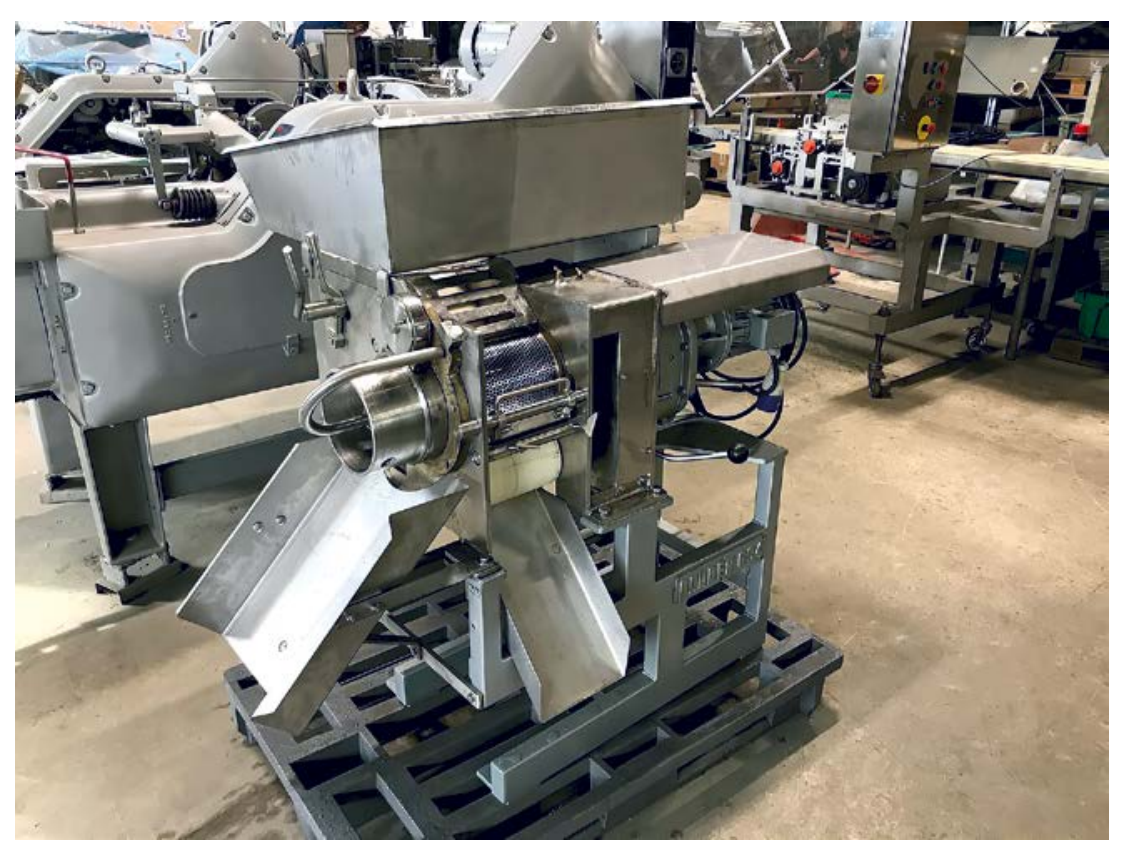

5. attēls. Galas-kaulu separators „Baader 694»
Nonākot mehāniskajā atkaulošanas presē, zivis iziet cauri preses cilindriem un perforētai lentei, pie tam, šĩ procesa laikā, muskuḷaudi tiek izspiesti cauri sīkajām cilindra atverēm, sasmalcinot tos līdz maltās galàs stāvoklim.

Āda, asakas, zvīnas iziet cauri speciālam novadišanas kanālam. Zivju separatori atdala zivju gạlu no zvīṇām un asakām. Šajā laikā maltā gala vairākkārtīgi tiek skalota ar ūdeni, lai nodrošinātu masas struktūras viendabīgumu un pagarinātu uzglabāšanas termiṇus.

Šādā veidā iegūtas maltās galas reoloǵiskās īpašības parasti pilnībā neapmierina pārstrādātāju prasības, tāpēc malto galı stabilizēe pievienojot pārtikas piedevas. Šis tehnoloǵijas trūkumi ir lielais ūdens patērinšs un papildu aprīkojuma - vibrosieta, centrifūgas, maisītāja/ kutera nepieciešamība.

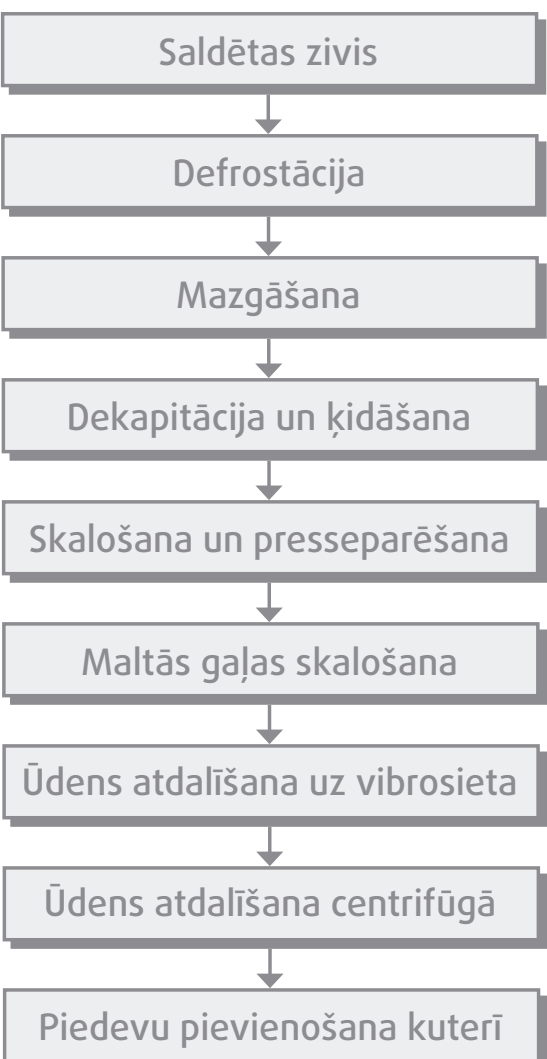

Attēlotajā tehnoloǵiskajā shēmā nav paredzēta gatavas maltās gallas sasaldēšana. Pēc sagatavošanas maltā gala tiek nosūtīta pārtikas produktu tālākam ražošanas procesam.

\section{6. attēls.}

Zivju maltās galas ražošanas, izmantojot neopresi, tehnoloǵiskā shēma 
Gatavās zivju maltās galas apjoms, ražojot pēc šādas tehnoloǵiskās shēmas, vidēji veido 22-32\% no izejvielu masas. Šìs zivju maltās galas tehnoloǵiskās shēmas modifikācijā ir varianti ar divreizēju un vienreizēju sasmalcinātas zivju galas skalošanu ar ūdeni.Lai samazinātu ūdens patēriṇu maltās galas skalošanai, no asakām un ādas atdalìtu zivju gaḷ presē, bet, lai atbrīvotos no ūdenī škīistošajām slāpekli saturošajām vielām, to paklauj vienreizējai skalošanai ar ūdeni, kur ūdens:maltās galas attiecība ir 6:1. Šis panēmiens lauj atdalìt no zivju gaḷas 25-25\% visu slāpekli saturošo savienojumu, bet neolbaltumvielu - lìdz 90\% no to sākotnējā satura.

Pèc citas tehnoloǵijas malto galu, kas iegūta, izmantojot neopresi, ievieto speciālà tvertnēe, kur to maisa ar ūdeni attiecībā 1:3-10 apmēram 15 minūtes, bet pēc tam galı vēl sajauc ar üdeni. Pēc otrreizējas skalošanas ūdeni atdala ar centrifūgas palīdzību, bet iegūto malto galu sasaldē.

Ražošanas procesa izpētes laikā tika izmēǵināta tehnoloǵija, saskaṇāa ar kuru zivis pēc skalošanas tika sagrieztas sīkos gabalin,os (10 mm izmērā), 0,5 sek. apstrādātas ar tvaiku, kura temperatūra ir 100-105 ${ }^{\circ} \mathrm{C}$ vai 1 sek. ar üdeni, kura temperatūra bija 100-105 ${ }^{\circ} \mathrm{C}$, tad tās tika strauji atdzesētas, skalotas un pēc ūdens atdališanas izlaistas caur neopresi, lai atdalìtu zivju galu no asakām un galvām.

Par turpmāk aprakstîtā paṇēmiena, kas paredzēts sīku, nesadalìtu zivju apstrādei, pamatu ir kluvvusi „norvēǵu tehnoloǵija». Zivis vispirms sagriež 1-2 cm garos gabalin,os, sajauc ar vienlīdzīgu ūdens daudzumu, pazemina skābumu, izmantojot etikskābi vai propionskābi līdz pH=4, masu vienmērīgi izmaisa. Tādējādi zivju gala klūst blīvāka, kas veicina ādas, taukaudu, iekšējo orgānu un tumšās vēderplēves atdalī̌sanos un to aizvadīšanu kopā ar ūdens maisijumu. Pēc tam gạlu atdala no kauliem, iedarbojoties uz to ar ūdens strūklu zem spiediena, pēc kā lieko ūdeni aizvada, izmantojot presi. Izmantojot šo pan,êmienu, galas izlaides apjoms vidēji ir 35-40\%.

Taču sīko zivju sadalǐšana mazākos gabalos ir darbietilpīgs process, un tas kavē pilnvērtīgi izmantot šos tehnoloǵiskos panēmienus, lai no tām gatavotu malto gạlu. Turklāt lielais ūdens patērinçš un Iīdzās neopresei nepieciešamā aprïkojuma lielais daudzums, pat ja attaisno sevi, padara maltās gạlas ražošanu no mazizmēra zivju sugām ekonomiski neizdevīgu. Sāda tendence ir novērojama pat tad, ja tiek ražota maltā gala no blakusproduktiem, kas palikuši pēc lielo sugu zivju sadalīšanas filejās.

\subsection{ZIVJU MALTĀS GALASAS RAŽOŠANA, IZMANTOJOT KUTERI}

lepriekš aprakstītajā tehnoloǵiskajā procesā, lai pievienotu pārtikas piedevas izgatavotajā maltajā gặă, tiek izmantots maisitājs vai kuteris. Gatavojot malto galu no mazizmēra zivīm, visas ražošanas operācijas iespējams veikt, izmantojot liela ātruma smalcināšanas iekārtu - kuteri (7.att.).

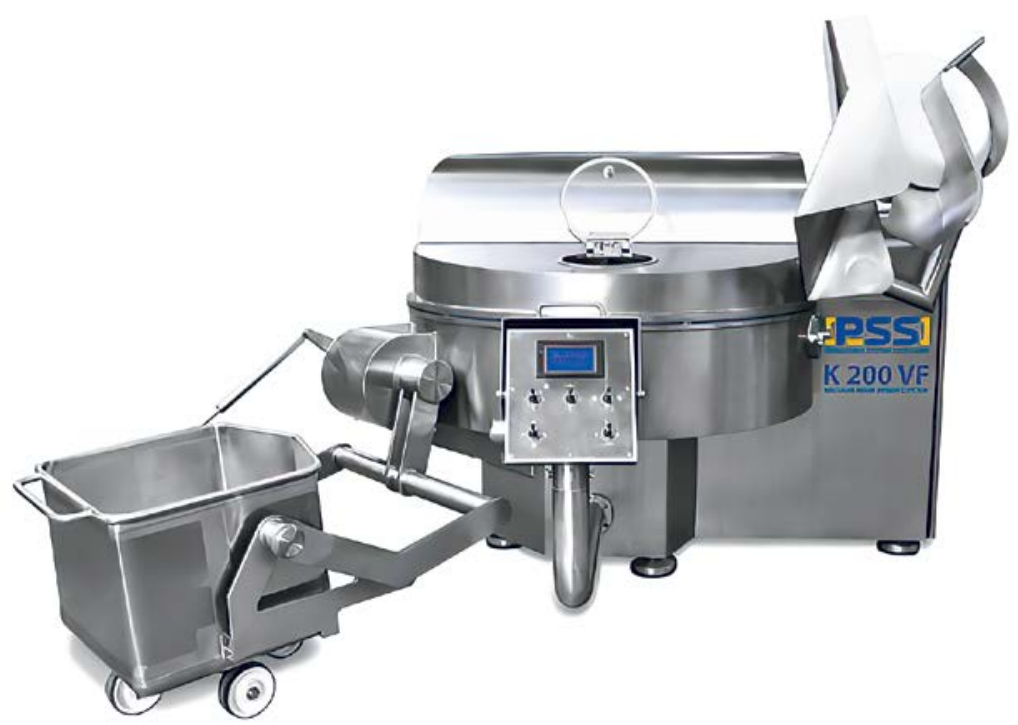

7. attēls. Kuteris „Laska K200»

Kuteris sastāv no divām galvenajām dạlām: rotējoša kausa, kurā tiek ievietota izejviela, un nažiem, kas veic smalcināšanu. Kausa tilpums nosaka ielādes apjomu un, attiecīgi, iekārtas ražošanas jaudu vienā kuterēšanas ciklā. Nažu galva ir mezgls, ar kura palīdzību notiek izejvielu smalcināšana. Tà sastāv no vārpstas, pie kuras ir piestiprināti no 6 līdz 10 nažiem (atkarībā no modela ražošanas jaudas un kutera paredzētā pielietojuma). Nažu griešanās ātrums variē atkarībā no 
ielādes apjoma un ražošanas jaudas - no 1500 lĩdz 6000 apgr./min Modernajos kuteros paredzētas ierīces produktu mehāniskai ielādei un izlādei, ūdens vai sālījuma dozēšanai, produkta smalcināšanas ilguma regulēšanai. Kuterī ievieto saldētas zivis, ūdeni, pārtikas piedevas un sastāvdalalas, bet kuterēšanas beigās iegūst gatavu malto galu.
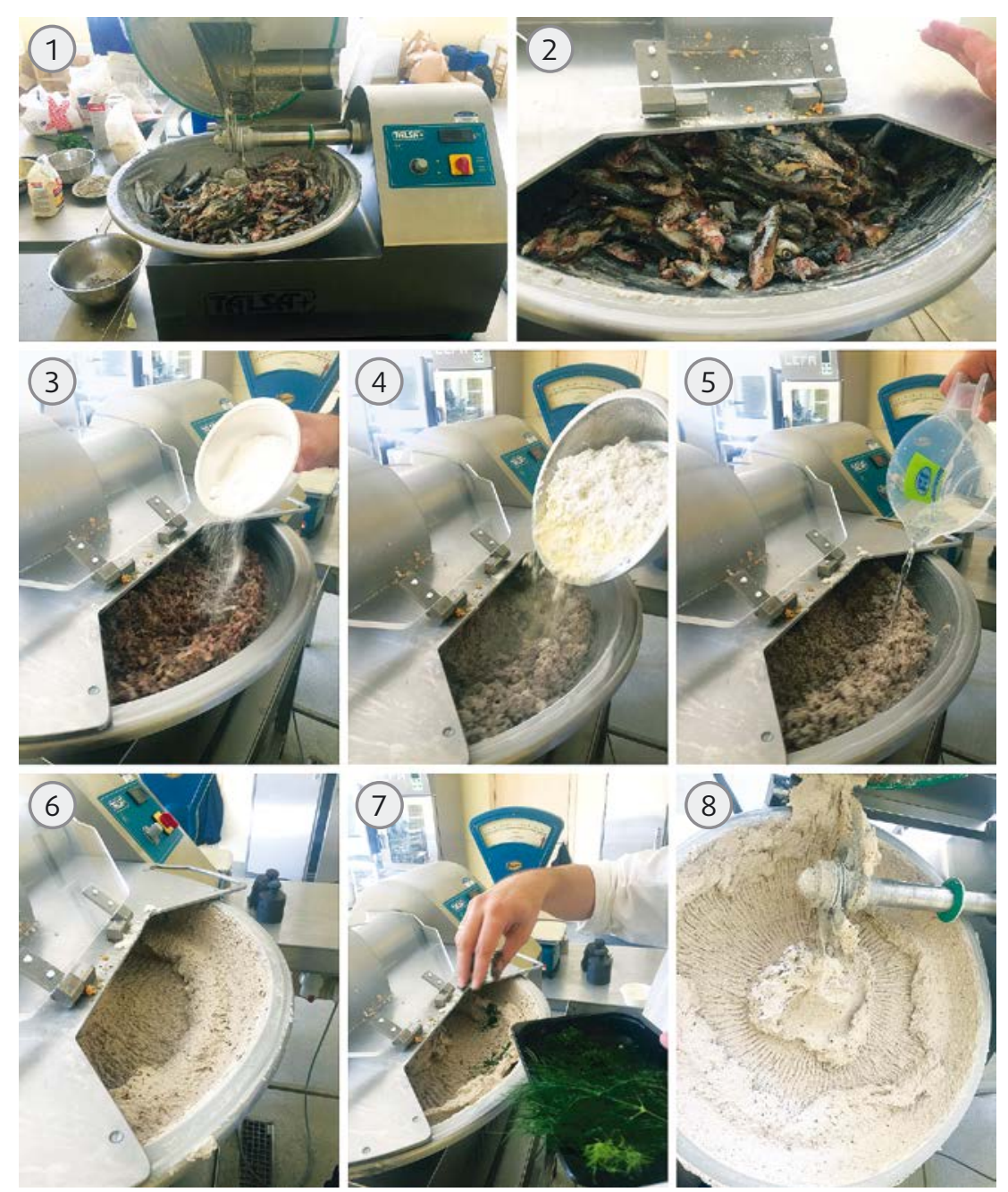

8. attēls. Zivju maltās gallas pagatavošanas process, izmantojot kuteri
Kuteris dod iespēju sasmalcināt saldētas zivis bez iepriekšējas defrostācijas, kas palīdz būtiski ietaupìt tehnoloǵiskā procesa laiku un ražošanas platību. Turklāt zivis nav paklautas papildu mikrobioloǵiskajam piesārṇojumam, nenotiek muskuḷaudu sulas zudumi, kas novērojami defrostācijas laikā, kā arī netiek patērēts üdens maltās gaḷas skalošanai. Kuterēšanas laikā produkti sasilst no kontakta ar kutera kausu un ātri rotējošajiem nažiem, kā rezultātā pazeminās gatavā produkta kvalitāte un uzglabāšanas terminç̌. Saldētu izejvielu smalcināšana lauj samazināt zivju masas uzsilšanu.

Faktiski viss maltās galas ražošanas tehnoloǵiskais process tiek realizēts kutera kausā, kā rezultātā pazeminās produkta mikrobiālais piesārn, ojums un oksidatīvā bojāšanās, kas, pārvietojot malto gạlu no neopresēm uz maltās galas maisītāju, ir neizbēgama. Kuteriem ir iespējams regulēt smalcināšanas režĩmus - lielākos gabaliṇos vai mazākos, savukārt neopresēm ir cilindri ar neregulējamiem kanālu diametriem. Gatavā produkta reoloǵiskos un organoleptiskos rādītājus iespējams regulēt tieši kuterēšanas procesā, pievienojot maltajā gạāa nepieciešamās vielas, un maisît pievienotās sastāvdalas bez iepriekšejjas smalcināšanas. Smalcinot kuterī veselas zivis, neveidojas blakusprodukti, kurus būtu nepieciešams atseviški utilizēt, turklāt maltā gala tiek bagātināta ar viegli asimilējamu kalciju

Kuteris lauj regulēt maltās galas blīvumu un iegūt tādu malto galı, kas turpmāk veido noteiktu „rakstu» gatavā produkta škēersgriezumā. To iespējams panākt, pievienojot maltajā galā kontrastējošas sastāvdalılas - sākot no rupji maltām garšvielām un garšaugiem un beidzot ar tādām sastāvdalām kā olas, kartupeli, zalie zirnîši un tml.

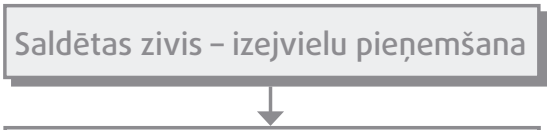

Rupja smalcināšana, izmantojo blokgriezēju

Smalcināšana ar kuteri pievienošana
Funkcionālo piedevu
9. attēls.

Maltās galas

ražošanas

tehnoloǵiskā shēma, izmantojot kuter 
Saldētas mazizmēra zivis ražošanā nonāk standarta blokos ar vidējo svaru līdz $15 \mathrm{~kg}$. Lai sasmalcinātu saldētus zivju blokus līdz standarta gabaliem (parasti izmēros lïdz $5 \times 5 \times 5 \mathrm{~cm}$ ), tiek izmantots blokgriezējs. Šĩ operācija harmonizē kutera darbu, lauj paātrināt un atvieglot saldētu zivju smalcināšanas sākotnējo posmu, kā arī pazemināt slodzi uz nažiem un citām kutera detalām.

Izejvielu kuterēšana ir jāveic maksimāli smalki, lai likvidētu maltās galas neviendabīgumu, taču vienlaicīgi ir jāizvairās no pārāk ilga kuterēšanas procesa, jo tas var novest pie šũnu sieninu pārmērīgas sagraušanas, šūnu škidruma iztecēšanas, maltās galas reoloǵisko īpašību izmainām un, attiecīgi, stabilizējošo piedevu paaugstināta patēriṇa. Maltās galalas sasilšana kontaktāar ātri rotējošo kutera kausu un nažiem notiek visa kuterēšanas procesa un sastāvdalu pievienošanas laikā. Maltās galas pārkaršana var izraisit zivju olbaltumvielu denaturāciju, kas samazinās maltās gaḷas mitruma noturēšanas spēju, kāa ari pazeminās gatavo maltās galas produktu organolaptiskos kvalitātes rādìtājus. Kuterēšanu veic lĩdz tiek sasniegta optimālā maltās galalas konsistence, vienlaicīgi nepielaujot temperatūras paaugstināšanos lìdz $-4 \ldots-2{ }^{\circ} \mathrm{C}$, kas tiek kontrolēta ar kuterim pievienota termometra palīdzību.

Tiek ražoti divu veidu kuteri: tādi, kas strādā atmosfēras spiedienā (atvērtie), un tādi, kas strādā vakuumā (aizvērtie). Vakuuma kuteru pielietošana lauj uzlabot produkta krāsu un mikrobioloǵisko stāvokli, jo tajos ir izslēgta gaisa skābekla piekluve smalcināmajam produktam, kas, savukārt, samazina zivju izejvielu oksidatīvo bojāšanos, homogēnās masas aerāciju, palielina tās blīvumu. Kuterus var aprīkot ar kausa apsildes vai atdzesēěsnas opciju. Tas ir îpaši svarīgi, gatavojot malto galı, jo, nažiem ātri griežoties, izejvielas viegli „apvārās». Zema temperatūra nepielauj šo „apvārǐšanos», līdz ar to maltā gala ilgāk saglabājas svaiga.

\section{ZIVJU MALTĀS GALAS TEHNOLOGIISKĀS ĪPAŠİBAS}

Z _ivju pārstrādes procesā notiek to audu struktūras sagraušana, fermentu atbrìvošanās no šūnām un fermentiem nonākot kontaktā ar substrātiem, paātrinās kīmiskās reakcijas. Šo iemeslu dēl saldēta maltā galı uzglabāšanas laikā ātrāk nekā fileja tiek paklauta nelabvēlīgām izmaiṇām.

Nelielas izmainas receptēs var izsaukt vērā nemamas produkta īpašību izmainas. Zivju maltās gaḷas kvalitāte ir atkarīga no tās reoloǵiskajiem raksturlielumiem, tādē! ir loti svarīgi to kontrolmērijumi, ar mērki savlaicīgi veikt nepieciešamos korekcijas pasākumus.

Viskozitāte un adhēzija ir zivju maltās gallas fiziskās īpašības, kas nodrošina ražošanas tehnoloǵiskā procesa mijiedarbību ar aprīkojumu. Šìs īpašības tiek regulētas, pievienojot nepieciešamos stabilizatorus.

Ar maltās galas viskozitāti saprot tās īpašību pretdarboties savai kustībai.

Zivju maltajai gạlai no reoloǵijas viedokla piemît viskozi plastiska struktūra. Maltās galalas viskozitāti nosaka ar ierīcēm - viskozimetriem.

Viskozitātes parametrs lielā mērāa ir atkarīgs no temperatūras, kas paaugstinās ilgstošas smalcināšanas laikā. No tehnoloǵijas viedokḷa, iespēju robežās nedrīkst pielaut maltās galas pārmērīgu uzsilšanu (ne vairāk par $0 \ldots+2^{\circ} \mathrm{C}$ ).

Ar adhēziju vai pielipšanu saprot īpašību, kas raksturo heterogēnu kermen,u virsmu sakeri, divu kermen,u mijiedarbību starp to robežvirsmām. Zivju maltās gallas adhēzijas rādìtājam ir liela nozīme brīdī, kad tiek veikts tehnoloǵijas adaptācijas process ražošanā esošajam aprīkojumam, kas saistīts ar temperatūras - mitruma režīma ìpatnībām maltās galas ražošanas laikā. 
Divu kermenu adhēziju ir pienemts raksturot ar: atrāvuma spēku, atrāvuma īpatnējo darbu, kas attiecināts uz laukuma vienību; laiku, kas nepieciešams, lai izjauktu saikni starp substrātu un adhezīvu, noteiktas slodzes iedarbībā.

Bieži adhēziju raksturo arī ar minimālo spēku, kas nepieciešams atrāvumam. Šo lielumu sauc par adhēzijas izturību, adhēzijas spiedienu (spriegumu), pielipšanas spiedienu vai ĩpatnējo pielipšanu Adhēzijas spēku mēra ar ierīcēm - „adheziometriem» jeb saḳeres mērītājiem.

Zivju maltā gaḷa pēc bīdes stiprïbas lieluma ien,em vietu starp škidriem un cietiem kermeniem, kam piemît vienlaicīgi tvirti elastīgas un plastiskas ĩpašibas

Maltā gala ir reāls, nevis ideāls izpētes objekts, tas nozīmē to, ka viena un tā pati maltā galı dažādos ārējos apstākḷos var demonstrēt dažādas îpašỉbas. No ražošanas tehnoloǵijas viedokla ir jāidentificē zivju maltās galas reoloǵisko īpašību izpausmju atkarība no tās sastāva un apstākliem, un jāizmanto šis ĩpatnības ražošanas optimizācijai. Laikā, kad maltā gaḷa tiek padota ar sūkṇiem un pa caurụılvadiem, ir vēlams samazināt tās viskozitāti, bet, formējot uz iepakošanas aprīkojuma, ir vēlams palielināt viskozitāti un padarît malto gaḷu mazāk tekošu.

Konsistence ir saistîta ne tikai ar produkta garšas īpašǐbām, bet arī ietekmē sagremojamību un raksturo produkta svaigumu. Neraugoties uz zināmu maltās gaḷas konsistences novērtējuma atkarību no bīdes īpašīām, tās noteikšanas rezultāti saskan ar produkta organoleptikajām īpašǐām.

Viennozīmīga konsistences sajūtas interpretācija ir apgrūtināta uztveres ĩpatnību dẹ!, kā arī tāpēc, ka šì produktu īpašība tiek noteikta fizikāli.Konsistences sensorais novērtējums, kuru var raksturot arī kā materiāla deformatīvās uzvedības empīrisku raksturojumu, bija jau pazīstams pirms plašākas reoloǵiskās analīzes pielietošanas, un tas tiek izmantots līdz pat šim brīdim.

Šis kvalitātes rādîtājs pietiekamā līmenī atspoguḷo analizējamās reoloǵiskās īpašỉbas un nodrošina pārtikas produktu ātru kontroli viena vai otra parametra atbilstībai vai novirzei no nominālās vērtības. Pārtikas produkti un izejvielas, kas ir bioloǵiski aktīvi materiāli, ir nenoturīgas dispersas sistēmas, kuras tiek bieži paklautas straujām izmainām, kas ietekmē reoloǵiskās īpašības, tāpēc konsistences novērtējums atsevišḳos gadijumos var būt vienīgā reoloǵiskās analīzes metode.

Kombinētas zivju maltās galas mitruma noturēšanas spējas (MNS) noteikšana ir svarīga gan no ekonomiskā, gan tehnoloǵiskā viedokla

Zivju maltajā gạ̦ā, kuru ražo no mazizmēra zivīm, ir augsts mitruma saturs. Tà kā mitruma daudzums, ko pievieno maltajai gaḷai un kuru tā zaudē termiskās apstrādes procesā, tieši ietekmē ražošanas ekonomisko lietderīgumu, maltās gạlas spēja noturēt vai nu savu, vai no ārpuses pievienotu mitrumu ir loti svarīgs rādîtājs.

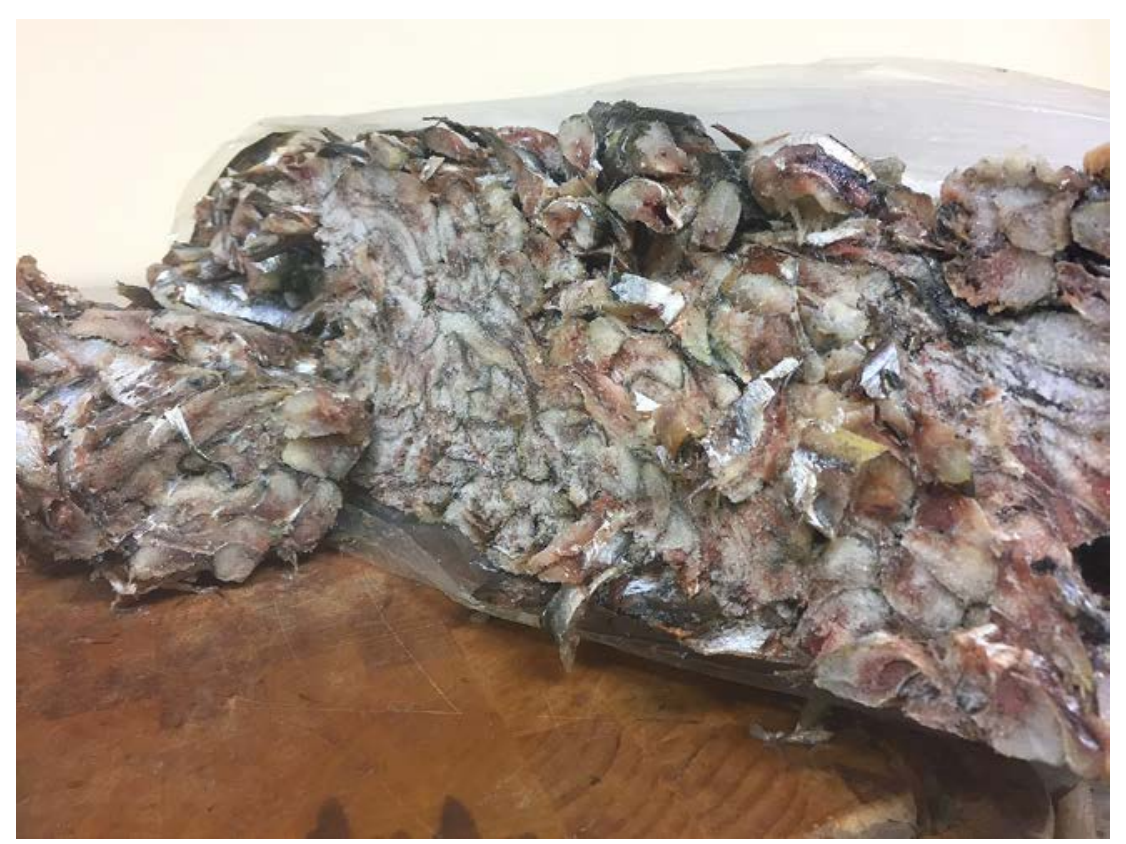

10. attēls. Piegādātajām mazizmēra zivju izejvielām raksturīgs gan savs, gan no ārienes pievienots mitrums 
Zivju maltās galas mitruma noturēšanas spēja ir starpība starp mitruma saturu maltajā galāa un mitruma daudzumu, kas ir izdalījies termiskās apstrādes procesā. Gatavās produkcijas ieguves apjoms būs tieši atkarīgs no pārtikas piedevu, kuras tiks pievienotas, lai regulētu MNS, funkcionāli tehnoloǵiskajām īpašībām.

Viszemākā mitruma noturēšanas spēja ir vidēji sasmalcinātai maltajai galai ar dalinu izmēru 1,5-3 mm. Ja dalinu izmērs ir lielāks vai mazāks par 1 mm, MNS pieaug, ko pirmajā gadijumā nosaka mazāka muskulalaudu sākotnējās struktūras bojājumu pakāpe, bet otrajā - pieaugoša üdenī škīistošu un üdens saistǐšanas laikā uzbriedušo olbaltumvielu frakcijas dala.

\section{NO MAZIZMËRA ZIVĪM IZGATAVOTAS MALTĀS GALAS STABILIZĀCIJA}

Mažojot zivju malto galı,u, ražotājam nākas meklēt līdzsvaru starp diviem pretējiem mērḳiem. Tirgus prasa maksimāli lētu, stabili augstas kvalitātes produktu ar garu uzglabāšanas terminu un minimālu pārtikas piedevu izmantošanu. Taču stabilas kvalitātes produkcijas ražošana no zivīm, kurām gada laikā novērojamas dabiskas sezonālās sastāva un kvalitātes svārstības, nav iespējama bez plašāka pārtikas piedevu pielietojuma. Turklāt jān,em vērā sastāvdalı ekonomiskā lietderība, jo mazizmēra zivis (brētlinas) ir lēta izejviela un dažādu sastāvdalı pievienošana neizbēgami sadārdzina galaproduktu.

Gatavojot malto galu no mazizmēra zivīm, iegūst bāzes malto galı, kuru var izmantot dažādu zivju produktu ražošanai. No sasmalcinātas bāzes zivju maltās galas iespējams izgatavot plašu pārtikas produktu sortimentu, kas atbilst dažādām prasībām un dažādiem sākotnējās maltās gaḷas raksturlielumiem. Tādẹl brētliṇu maltās gaḷas produktu ražošanas tehnoloǵisko procesu ir lietderīgi sadalīt divos posmos: zivju izejvielu pārstrāde standartizētā bāzes maltajā galā un plaša sortimenta pārtikas produktu ražošana no bāzes maltās galas. Turklāt tūlîtēja bāzes maltās galas nodošana turpmākai ražošanai atrisina problēmu ar tās uzglabāšanas termiṇu stabilizāciju.

\subsection{MALTĀS GALAS STRUKTŪRAS FORMÉŠANAS PANËMIEN}

Sasmalcinātām zivīm piemīt ne visai augsti reoloǵiskie rādītāji - šai masai ir zema viskozitāte, augsta plūstamība, kas apgrūtina formētu pārtikas produktu izgatavošanu. Tādēl pārtikas produktu gatavošanas procesā no zivju maltās galas nevar iztikt bez pārtikas piedevām, kas uzlabo maltās galas fizikāli tehnoloǵiskos parametrus. Smalki sasmalcinātas maltās galas konsistences uzlabošana tiek panākta, papildus pievienojot dažādas izejvielas: pārtikas škiedras, dažādu škirnu zirnu miltus, mannas putraimus, sojas teksturātu u.c. 
Sastāvdalu izvēles galvenais kritērijs - nelielā cena, zināma izmantošanas tehnoloǵija, paredzama ietekme uz maltās gal,as īpašībām.

Pārtikas šk̦iedras, kas iegūtas no kviešu un burkānu škiedrvielām, saista lieko mitrumu, bagātina produktu ar šḳiedrvielām (sabalansēts uzturs) un uzlabo gatavās produkcijas organoleptiskās īpašības.

Zirṇu miltiem piemīt neitrāla garša, kas dalêji maskē specifisko zivju piegaršu, bagātina produktu ar pākšaugu olbaltumvielām, un tie tiek ražoti Latvijā.

Mannas putraimi tiek plaši izmantoti kā sastāvdala emulǵēto izstrādājumu ražošanai, tie ir lēta un droša izejviela.

Sojas teksturāts pieški maltās gaḷas produktiem patīkamu, parupju konsistenci, kuru patērētāji sagaida no kapātiem pusfabrikātiem, sasaista lieko mitrumu un bagātina produktu ar pilnvērtīgām olbaltumvielām.

lespējams izmainît arī maltās galas konsistenci, pievienojot sarežǵītākus, kompleksus preparātus - hidrokoloīdus: karaginānus, sveḳus utt. Taču pamatizejvielu - brētliṇu cena ir ievērojami zemāka par šo dārgo izejvielu cenu, kas padara to pielietošanu ekonomiski neizdevīgu.

\subsection{MALTĀS GALAS KRĀSAS STABILIZĀCIJA}

Sasmalcinātai maltajai galai var būt dažādi krāsas toṇi, kas ir atkarīgi no zivju izejvielu stāvokla un zivju škirnes, taču jebkurā gadỉjumā tā ir pelēkbrūnā krāsā. Tas ir saistīts ar to, ka zivju pelēkie muskulaudi sajaucas ar tumšāko ādu, turklāt maltās galas tumšās nokrāsas rašanos arī veicina tās mijiedarbība ar gaisa skābekli (lipīdu oksidācija), kuru iemaisa maltajā gaḷāātri rotējošie kutera naži. Strādājot ar vakuuma kuteri, krāsa būs gaišāka, taču jebkurā gadījumā maltās gaḷas krāsa ir jākoriǵē līdz patērētājam vairāk pien,emamam tonim.

Lai ievērojami izmainītu zivju maltās galas un maltās gaḷas produktu krāsu, ir jāizmanto pārtikas pigmenti un krāsvielas.

Lai pieškiritu maltās gạlas masai gaišāku krāsu, visefektīvāk ir izmantot E171 (titāna dioksīdu). Atkarībā no pievienotā vielas daudzuma zivju maltās galas masa iegūst dažādu tonu gaiši pelēku nokrāsu. Kā noskaidrots, tad pievienojot titāna dioḱsīdu līdz pat 0,4 - 0,6\%, maltā galı iegūst patērētājam pien,emamu gaiši pelēku krāsu. Titāna dioksīds jāpievieno jau sākotnējā kuterēšanas stadijā, pirms pārējo piedevu pievienošanas, pretējā gadījumā būs nepieciešams daudz lielāks E171 daudzums. Tas ir saistīts ar to, ka būs jāiekrāso jau visas maltās galas masa, ne tikai sasmalcināta zivju masa. Maltās gaḷas masas gaišas krāsas rašanos būtiski veicina dārza sīpoli, pateicoties to sastāvā ietilpstošajiem antioksidantiem.

Tālāku bāzes maltās gaḷs krāsas regulēšanu ir jāveic ar atlauto pārtikas krāsvielu palīdzību, gatavojot konkrētu produktu, atbilstoši šî produkta krāsai. Prakse ir pierādījusi, ka, lai pieškirtu maltajai galai rozā vai gaiši dzeltenu toni, ir racionāli izmantot paprikas ekstraktu (škidrā veidā), taču šis ir samērā dārgs risinājums. Ir iespējams arī izmantot sintētiskās krāsvielas, piemēram, tartrazīnu (E102), annato (E160) vai ponso 4R (E124). Lai pieškirtu produktam bēšu vai pelēku toni, var izmantot krāsvielas uz dedzināta cukura vai karameles bāzes (E150).

\subsection{MALTĀS GALAS PRODUKTU GARŠAŚ STABILIZĀCIJA}

Maltās galas produktu garšas rādītājus nosaka izmantotās izejvielas - mazizmēra brētliñas ar samērà zemiem organoleptiskajiem rādītājiem, kuras tiek sasmalcinātas nesadalītas - ar galvu un iekšējiem orgāniem. Palielinot maltajā gaḷa sasmalcinātu brētliṇu koncentrāciju virs 50\%, tās organoleptiskie rādītāji pazeminās - pasliktinās garša, krāsa un konsistence. Zivju koncentrācijai samazinoties līdz 40\% - garšas radītāji ievērojami uzlabojas.

Sasmalcinātām veselām brētliṇām nepiemīt „smalka» garša, tādēl dārgu garšas un aromāta kompozīciju izmantošana ar citu zivju garšas niansēm (laša, līdakas, zandarta u.c. garša/aromāts) ir bezjēdzīga. Savukārt labus rezultātus ir izdevies iegūt, kā garšas bagātinātājus izmantojot kiplokus, sīpolus, melnos piparus u.c., kas raksturojas ar raupjām, asām un izteiktām garšas niansēm. Lai imitētu citu zivju sugu garšu, tika pievienoti, piemēram, laša, līdakas aromātu saturoši škiìdumi līdz 10\% no maltās galas masas daudzuma. 


\subsection{MALTĀS GAL̦AS LIPĪDU STABILIZĀCIJA}

Zivju lipīdiem ir raksturīgs augsts molekulmasas polinepiesātināto taukskābju daudzums, un tādēl tie ir loti jutīgi pret fermentatĩvo hidrolīzi un oksidatīvo bojāšanos, kas zivju maltajā gală paātrinās. Lipolîtiskās reakcijas (hidrolïze un lipīdu oksidācija) intensĩvi norisinās svaigā un atdzesētā zivju maltajā galā. Maltās galas triglicerīdu un fosfolipīdu hidrolīze veicina vērā n,emamu brīvo taukskābju pieaugumu, kā rezultātā maltajai galai parādās specifiska garša, smarža un var pasliktināties tās konsistence, kompleksu savienojumu starpā starp lipĩdiem un olbaltumvielām, veidošanās rezultātā.

Lai stabilizētu maltajā galas masā esošos lipĩdus, tiek izmantoti antioksidanti un sinerǵisti (kiimiskas vielas, kuras pastiprina citu vielu darbību, bet pašas paliek neaktīvas). Fenola antioksidanti (butilhidroksianizols, butilhidroksitoluols, butilhidroksichinolīns u.c.) ne vienmēr ir vienlīdz efektīvi, kas skaidrojams ar šo vielu hidrofobitāti un to, ka ir sarežǵíti tās vienmērīgi iemaisît maltās galas masā. To darbība pastiprinās, kad šīs vielas tiek izmantotas kombinācijā ar tādām ūdenī škịstošām skābēm kā askorbīnskābe un citronskābe, kurām ari piemīt sinerǵétiska iedarbība. Taukos škīstošo antioksidantu iedarbības efektivitāte paaugstinās līdz ar mitruma satura samazināšanos produktā. Lai stabilizētu zivju maltās galas lipīdus, tiek izmantoti arī dabiskie antioksidanti. Tie ne tikai kalpo kā oksidatīvās bojāšanās inhibitori, bet arī efektīvi maskē produkta garšas izmainas. No dabiskajiem produktiem šāda iedarbỉba piemìt sojas ellai, garšaugiem - anīsam, kardamonam, koriandram, dillēm, fenhelim, ingveram, sarkanajiem pipariem, dažiem graudaugu produktiem. Tajos esošās vielas ne tikai inhibē lipīdu oksidāciju, bet arī uzlabo maltās gạlas funkcionālās ipašības.
$R$

ažošanas laikā ir jānem vērā procesu tehnoloǵiskums, t.i., jādomà , kā minimizēt aprīkojuma dīkstāvi, samazināt iespējamo sastāvdaḷ pārkraušanu kutera kausā un atpaka!l. Kuterēšanas laikā masas smalcināšana ir jāveic ātri, lai izvairītos no nevajadzīgas temperatūras paaugstināšanās un produkcijas oksidēšanās. Tādẹ! maltās galas pagatavošana ietver šādus etapus:

1. Saldētu zivju rupja sasmalcināšana pie liela kutera nažu griešanās ātruma (šĩ operācija ir jāveic maksimāli ātri, vēlams vakuumā).

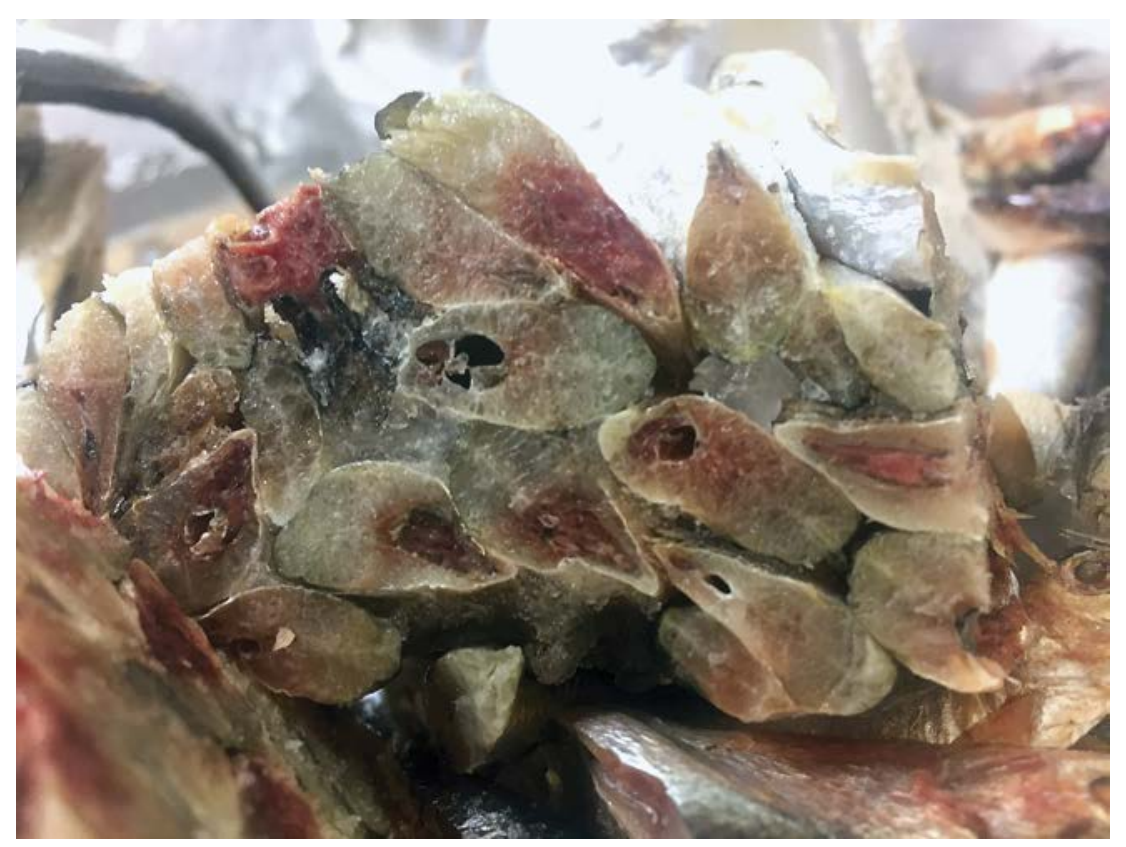

11. attēls. Smalcināšanai padodamo saldēto zivju sākotnējais stāvoklis 
2. Ūdenī škīstošo fosfātu un pārtikas sāls pievienošana zivju olbaltumu aktivizěšanai, kā arī titāna dioksīda E171 pievienošana maltās gallas krāsas korekcijai.

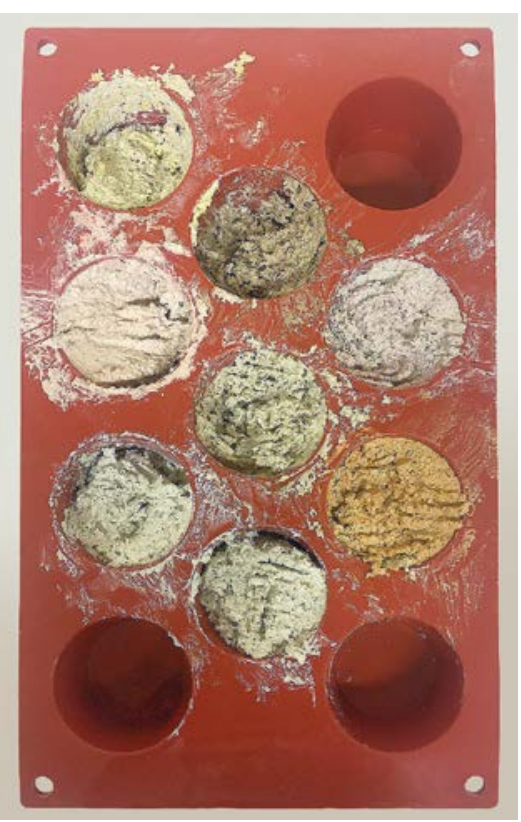

\section{2. attēls.}

Sasmalcinātas maltās gạlas krāsas korekciju iespējamās variācijas, kas iegūtas eksperimentālà ceḷà

3. Pārtikas škiedru pievienošana, lai uzlabotu struktūru, sasaistîtu no maltās gaḷas izdalījušos mitrumu un novērstu maltās gạlas pielipšanu pie kutera kausa virsmas, un tādējādi novērstu tās pārmērīgu sasilšanu.

4. Piena olbaltumvielu vai piena pulvera pievienošana, lai uzlabotu zivju maltās gạlas garšu un bagātinātu to ar olbaltumvielām, kas nepieciešamas stabilas emulsijas iegūšanai.

5. Aprēkinātās ūdens dalas pievienošana pārtikas škiedru hidratācijai (2,5 dalas uz 1 dalı škiedru)

6. Augu elllas pievienošana, lai pieškirtu viendabīgāku struktūru maltajai galai škēersgriezumā.

7. Kaltētu, ceptu vai svaigu sīpolu pievienošana.

8. Pildvielu un hidratēta sojas teksturāta (attiecībā 1:3), kā arī pildvielu hidratācijai paredzētā ūdens pievienošana.

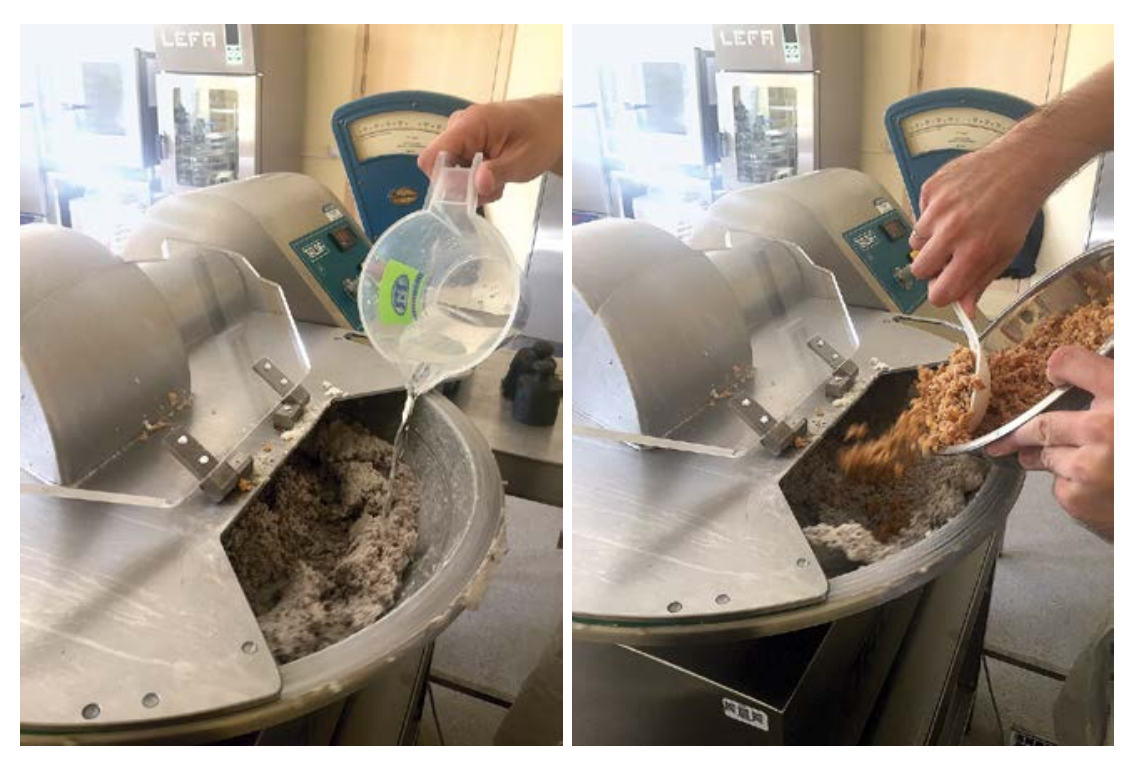

13. attēls. Pildvielu hidratācijai paredzētā ūdens un hidratēta sojas teksturāta pievienošana

9. Garšvielu vai garšas - aromāta kompozīcijas pievienošana.

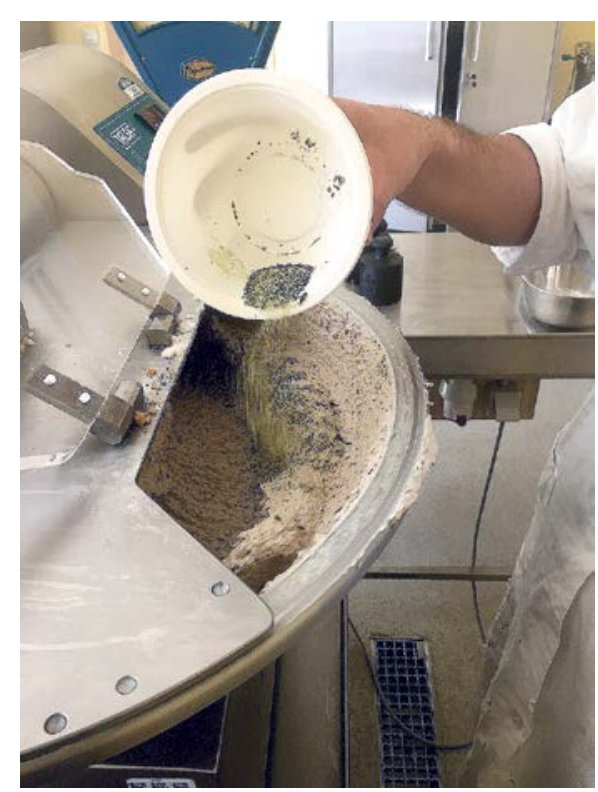

14. attēls.

Garšas - aromāta

kompozīcijas pievienošana 
10. Kuterēšanas process jāpārtrauc pirms maltā gala ir sasniegusi $+2{ }^{\circ} \mathrm{C}$ temperatūru, lai izvairītos no tās oksidatīvās un mikrobiālās bojāšanās.

11. Maltās gaḷas padošana turpmākai apstrādei.

12. Pēc smalkas sasmalcināšanas, īpašību stabilizācijas un fiksācijas šīs izejvielas ir kluvušas par viendabīgu, vidēji blīvu, krāsas un garšas ziṇā neitrālu masu - pusfabrikātu.

Atškirībā no sākotnējām izejvielām - sasmalcinātām brētlinām, bāzes maltajai galai nav raksturīgās lētu zivju piegaršas, un visiem produktiem no bāzes maltās galas pat bez garšvielu un garšas - aromatizējošo piedevu pievienošanas ir neitrāla zivju garša bez jebkādas specifiskas garšas un pēcgaršas.

Atškirībā no sasmalcinātām brētlinām bāzes malto galu var viegli iekrāsot jebkādā vēlamajā tonī un tai var pieškirt jebkādu konsistenci - no smalkas un maigas struktūras pildītai zivij, līdz raupjai, neviendabīgai kapātu zivju struktūrai kotletēs, pelmenos un pīrāgos. Tāpat tehnoloǵija lauj no bāzes maltās galas gatavot plānu, smērējamu zivju sviestus un izturīgas, griežamas vārītās desas.

\section{ZIVJU MALTĀS GALAS PRODUKCIJAS SORTIMENTA RAŽOŠANAS SHËMA}

1 _ai no bāzes maltās galas ražotu plašu zivju produktu sortimentu, ir nepieciešams aprīkojums produktu maltās gaḷas sastādišanai gan ar emulǵētu smalku (kuteris), gan ar rupju un neviendabīgu (maltās galıs maisīājs) struktūru. Vispiemērotākais ir šāds tehnoloǵiskais risinājums: 1) izejvielu cehā uz kutera sagatavotā maltā gala no brētlin’ām ar gliemežveida caurulvadu tiek nogādāta ražošanas cehā esošajā maltās gaḷas maisītājā; 2) vai arī tajā pašā kuterī tiek vēl vairāk sasmalcināta emulǵēto izstrādājumu (desu, sviestu, pastu) pagatavošanai. Maltās galas, pusfabrikātu un gatavo produktu transportēšana tiek realizēta, izmantojot gliemežtransportierus, kā arī sūkn,us un caurulvadus, gatavos produktus pārvieto ar lentveida transportieriem. Tiek izslēgta maltās galas, pusfabrikātu un gatavo izstrādājumu pārkraušana un pārvadāšana kastēs vai speciālajos ratinos. lepakoto produktu iekraušana tiek realizēta kastu iekraušanas vietās ar minimālu cilvēku lìdzdalību.

lepriekš aprakstītās bāzes maltās galas masas izmantošanas iespējas var attēlot noteiktos posmos un noteiktās līnijās (15.att.):

1. Zivju desu ražošanas līnija.

2. Zivju sviestu, pastas ražošanas līnija.

3. Zivju makaronu izstrādājumu un klimpu ražošanas līnija.

4. Kotlešu, pildìtu zivju, terīnu, frikadel̦ un teftel̦u ražošanas līnija.

5. Zivju pelmenu, makaronu, ravioli ražošanas līnija.

6. Kulinārijas izstrādājumu - pīrāgu, pīrādziṇu, rulešu ražošanas līnija. 


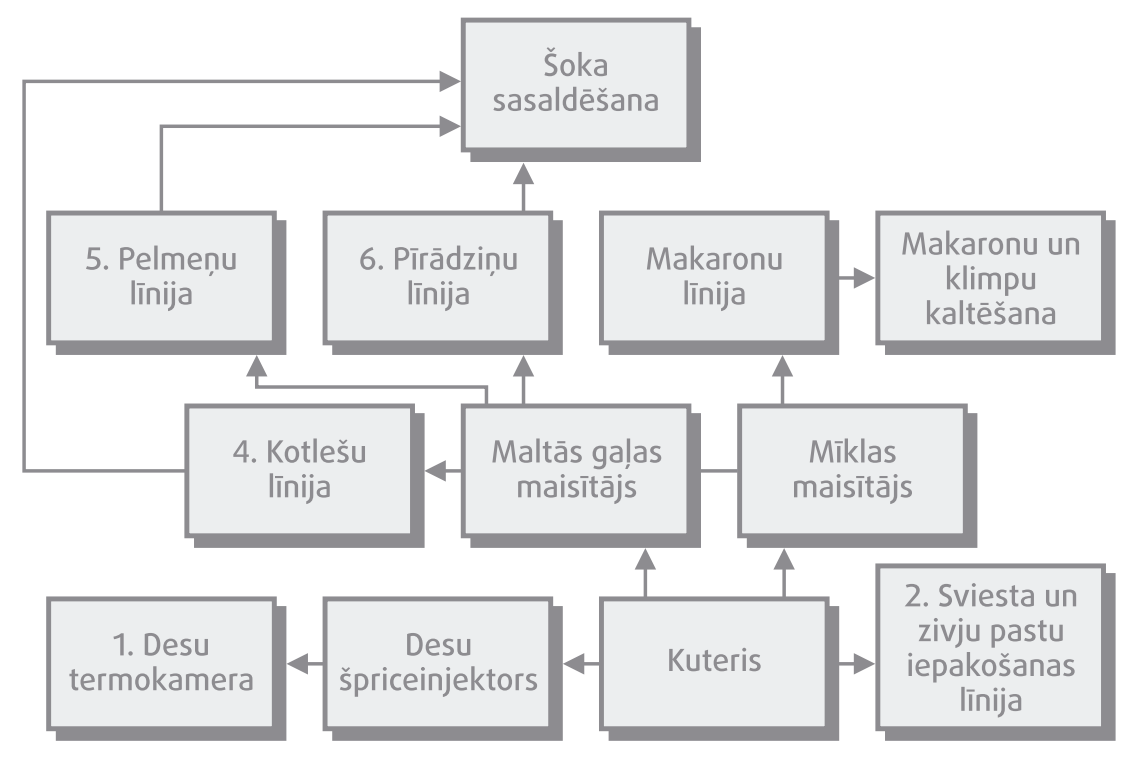

15. attēls. Aprīkojuma izkārtojuma vispārināta shēma (bultinass ir gliemežtransportieri un lentveida transportieri)

Savukārt gatavās produkcijas iepakošanas varianti var ievērojami atškirties, jo iepakošanas paṇēmiena izvēle vairāk attiecas uz mārketinga jomu un konkrētā uzn,ēmuma politiku (iepakošana polietilēna materiālā, kartonā utt.; gatavās produkcijas derīguma terminç̌; uzglabāšana atdzesētā vai saldētā stāvoklī; modificētas gāzes vides pielietošana vai vakuumēšana; individuālā iepakojuma izmērs).

\section{GATAVO IZSTRĀDĀJUMU} SORTIMENTS. SALDËTU, ATDZESËTU PUSFABRIKĀTU, ZIVJU DESU, PRODUKTU AR PILDĪJUMU UN ZIVJU MILTU IZSTRĀDĀJUMU RAŽOŠANAS ĪPATNĪBAS. ZIVJU MALTĀS GALAS UZKODAS UN PERSPEKTIVIE PRODUKTI

L

_ai pagatavotu klasiskos zivju ẽdienus, ir jāveic darbietilpīga un nehigiēniska zivju sadalǐšana, nepieredzējuši kulināri zivju tīrišsanas un kidāšanas laikā var iegūt traumas, kā arī šĩ procesa rezultātā veidojas liels daudzums atlikumu ar specifisku aromātu. Tas viss ierobežo pieprasījumu pēc zivīm, jo īpaši jauniešu vidū. Pastāv arī neliels risks aizrìties ar asakām, kas neveicina pieprasijjuma palielināšanos, un tas ir viens no iemesliem, kādēl patērētāji izvairās no zivju èdieniem un nedod tos saviem bērniem.

Modernajā pasaulē ar steigu un pastāvīgu laika deficītu, kas jāpatēēe èdiena pagatavošanai, aizvien lielāku popularitāti iegūst pusfabrikāti un gatavie kulinārijas izstrādājumiem, kuriem nepieciešama minimāla termiskā apstrāde vai tikai uzsildī̌ana. Piedāvāto pārtikas produktu, pusfabrikātu un kulinārijas izstrādājumu pamats ir brētliṇu bāzes maltā gala. Atbilstošu pārtikas piedevu, garšvielu un aromatizētāju kompozīciju pievienošana, atbilstoša formēšana un termiskā apstrāde lauj ražot plašu pārtikas produktu sortimentu. 


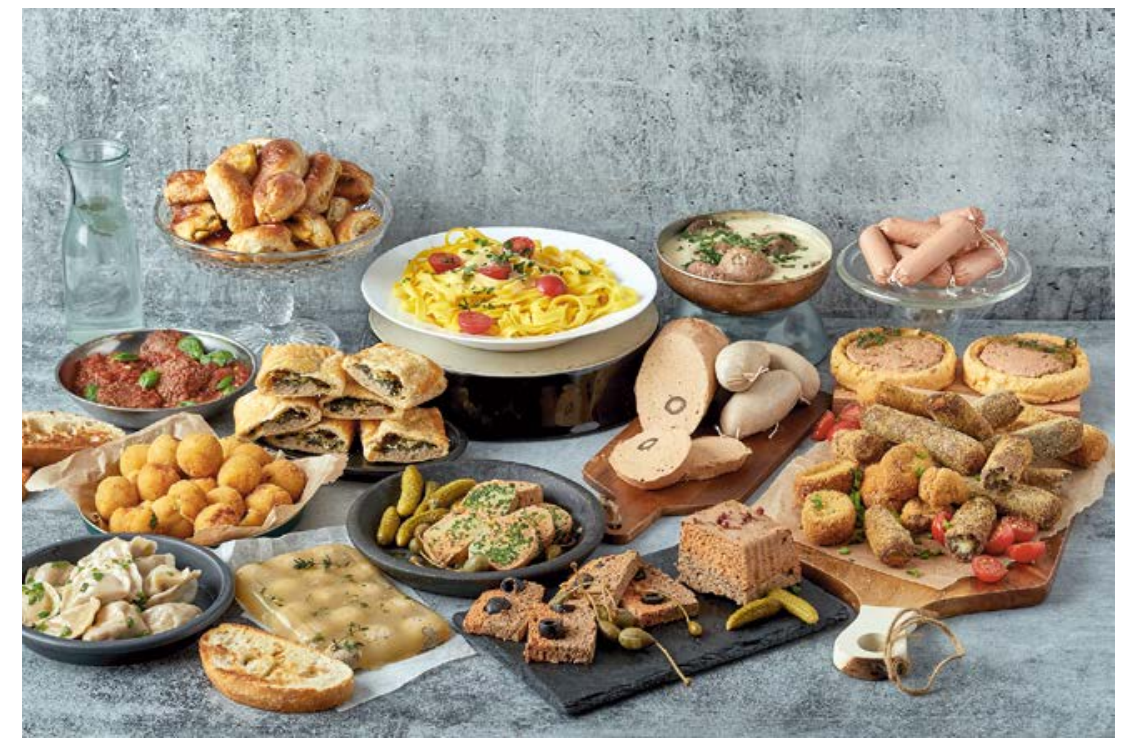

16. attēls. Pārtikas produkcijas sortiments, kas ražota no brētlinu bāzes maltās gaḷas, pievienojot atbilstošas pārtikas piedevas, garšvielas un aromatizētāju kompoziciijas, atbilstoša formēšana un

termiskā apstrāde lauj ražot plašu pārtikas produktu sortimentu

Pēc ražošanas un kulinārās apstrādes panēemiena produktus no zivju maltās gallas var klasificēt sekojošā veidā:

1. Saldēti kulinārijas izstrādājumi - zivju pelmeṇi, zivju pirkstiṇi, zivju kotletes, zivju burgeri.

2. Zivju miltu izstrādājumu kulinārija - uz pannas vai cepeškrāsnī cepti pīrādziṇi, pīrāgi ar pildījumu (kuḷebjaka), groziṇi, „vol-au-vent» no kārtainās mīklas un zivju pīrāgi.

3. Kulinārijas izstrādājumi no zivju maltās galas - pildīta zivs, „gefüllte fisch», sillku pastēte, zivju tefteli un frikadeles ar uzlējumiem un mērcēm, terīnes

4. Emulǵēti zivju desu izstrādājumi - vārītas zivju desas, cīsiṇi, sardeles.

5. Saldēti zivju - mīklas izstrādājumi - zivju makaronu izstrādājumi un zivju pasta, ravioli.
6. Emulǵēti zivju izstrādājumi - pastētes, zivju sviests, sviestmaižu masas.

7. Zivju produkti, kas imitē vēžveidīgo gạlu.

Visas 7.1. sadala uzskaitītās receptes ir orientējošas, jo precìza sastāvdalı piemeklēšana ir atkarīga no konkrētiem bāzes maltās galas kvalitātes rādītājiem un pārstrādājamo zivju sastāva.

\subsection{SALDĒTI KULINĀRIJAS IZSTRĀDĀJUMI - ZIVJU PELMENI, ZIVJU PIRKSTINI, ZIVJU KOTLETES, FIŠBURGERI, ZRAZI}

Šiem produktiem ir jābūt ar rupju struktūru, atškirīgu no smalki sasmalcinātas/emulǵētas maltās gallas, tādēl kapātu saldētu kulinārijas izstrādājumu ražošana tika organizēta divās stadijās: 1. Izejvielu smalka sasmalcināšana bāzes maltās galas ražošanai; 2. Šîs maltās galas biezināšana un teksturēšana, izmantojot pārtikas piedevas, kā arī dažāda veida termisko apstrādi.

Pēc tam sabiezinātai maltajai galai maltās galas maisitājā pievieno garšas un aromatizējošās piedevas, sīpolus, garšvielas, krāsvielas

Ražojot šādus kulinārijas izstrādājumus, ir noteikti jānem vērā, ka sastāvdạı maisišanai maltās gạlas maisītājā ir jānotiek ātri, jo ilgstošas maltās galas kuterēšanas laikā maltā gala stipri sasilst un paaugstinās mikrobiālās bojāšanās risks.

3. tabula. Maltās gaḷas receptes kotlešu, fišburgeru, pelmeṇu un zivju pirkstin,u ražošanai (kilogrami/100 kg)

\begin{tabular}{||l|c|c|c|c||}
\hline \multicolumn{1}{|c|}{ Sastāvdalas } & $\begin{array}{c}1 . \\
\text { variants }\end{array}$ & $\begin{array}{c}2 . \\
\text { variants }\end{array}$ & $\begin{array}{c}3 . \\
\text { variants }\end{array}$ & $\begin{array}{c}4 . \\
\text { variants }\end{array}$ \\
\hline Bāzes brētliṇu maltā galı & 60 & 55 & 50 & 45 \\
\hline Dārza sīpoli & 12 & - & 11 & 15 \\
\hline Kaltēti cepti sīpoli & - & 4 & 2 & 3 \\
\hline Sojas teksturāts & 8 & 10 & 4 & 6 \\
\hline
\end{tabular}




\begin{tabular}{||l|c|c|c|c||}
\hline \multicolumn{1}{|c|}{ Sastāvdaḷs } & $\begin{array}{c}1 . \\
\text { variants }\end{array}$ & $\begin{array}{c}2 . \\
\text { variants }\end{array}$ & $\begin{array}{c}3 . \\
\text { variants }\end{array}$ & $\begin{array}{c}4 . \\
\text { variants }\end{array}$ \\
\hline Pārtikas škiedras & 1,5 & 2 & 3 & 3 \\
\hline Sojas izolāts & - & 3 & 4 & 5 \\
\hline Ūdens & 16 & 22 & 8 & 10 \\
\hline Garšvielu maisijums 1 & 0,9 & 0,9 & - & - \\
\hline Garšvielu maisijums 2 & - & - & 1,2 & 1,3 \\
\hline Pārtikas sāls & 1,1 & 1,1 & 1,1 & 1,1 \\
\hline Ciete & 3 & 4 & 4 & 3 \\
\hline Margarīns & - & - & 12 & 8 \\
\hline Stabilizators 1 & 1 & - & 2 & - \\
\hline Stabilizators 2 & - & 1,5 & - & 2 \\
\hline Krāsviela „Paprika» & 0,05 & 0,05 & 0,06 & 0,06 \\
\hline
\end{tabular}

Zivju maltās galas pelmeni tiek gatavoti ar pelmen,u veidošanas iekārtas palīdzību, izmantojot standarta kviešu mīklu. Ražojot zivju pelmen,us, kam pievieno sagatavoto zivju malto galı, ūdens deva izvēlētajā receptē ir jāsamazina par 30\%, lai palielinātu maltās galas saistīgumu. leteicams pieturēties pie mīklas/maltā gala attiecības 40/60

\subsection{ZIVJU MILTU IZSTRĀDĀJUMU KULINĀRIJA - UZ PANNAS VAI CEPEŠKRĀSNĪ CEPTI PĪRĀDZINI, PİRĀGI AR PILDİJUMU („KULLEBJAKAS»), VALĒEJIE PİRĀDZINI (GROZINI), PĪRĀDZINI UN „VOL-AU-VENT» NO KĀRTAINĀS MĪKLAS \\ UN ZIVJU PİRĀGI}

Pēc zivju kotlešu, burgeru un zivju pirkstinu formēšanas ieteicams tos panēt, apmērcējot saistvielā un pēc tam panējumā. Šìs procedūras samazinās izstrādājumu pašizmaksu, pieškirs tiem pievilcīgu àrējo izskatu un nomaskēs iespējamos formēšanas defektus. Turklāt zivju izstrādājumu receptēs ietverta liela ūdens masas dalı,a, kas, gatavojot produktus taukvāres katlā un sasniedzot gatavību, var izraisìt to nevienmērīgu izplešanos un deformāciju. Pareiza mērcēšana saistvielà un panēšana var novērst iespējamo deformāciju.

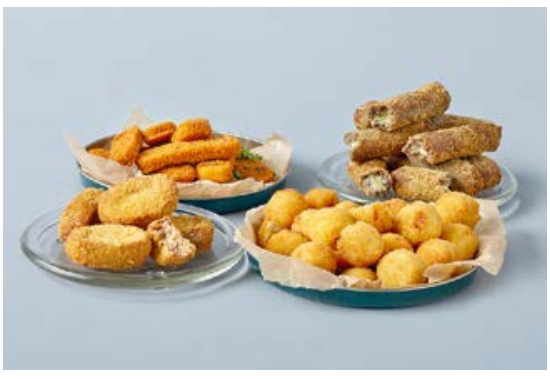

17. attēls. Saldēti kulinārijas izstrādājumi - zivju pirkstini, zivju kotletes, fišburgeri

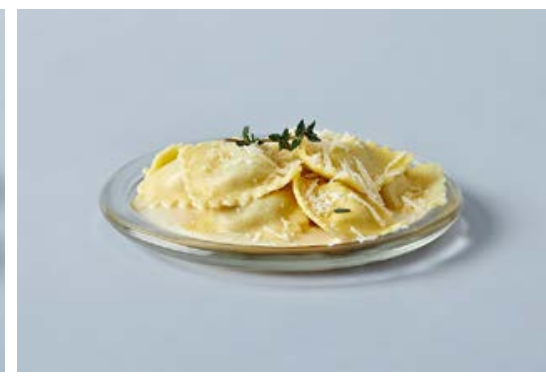

18. attēls. Saldēti kulinārijas izstrādājumi zivju pelmeni
Ražošanā mīklas gatavošanas, dozēšanas, pildišanas un formēšanas procesi parasti ir mehanizēti un tiek veikti, izmantojot automātiskās iekārtas, taču šajā projektā izstrādājumi tika gatavoti manuāli. Zivju pildijums var sastādìt 25-45\% no piraàga masas un, atkarībā no receptes, var tikt gatavots ar putraimu (rīsu, griḳu, grūbu), dārzen,u (puravu, zalı lociṇu un sīpolu, baklažānu, tomātu, dārzen,u ikru), kapātu olu u.c. piedevām.

Pīrādziṇus no skābās mīklas gatavo sekojošā veidā: mīklu gatavo no kviešu miltiem, miltus izsijā, pievieno siltā ūdenī izškīidinātu raugu, cukuru, augu ellı un sāli. Mïklu maisa līdz 12 minūtēm, līdz tiek iegūta viendabīga, elastīga masa. Mīklai, kas paredzēta zivju groziṇu pagatavošanai, maisišanas laikā pievieno olas. Mīklu atstāj uzbriešanai uz 2-3 stundām 20-30 ${ }^{\circ} \mathrm{C}$ temperatūrā.

Lai pagatavotu pildijumu, bāzes zivju malto gạlu maltās galas maisītājā samaisa kopā ar izvēlētajām sastāvdalāmm saskan,āa ar recepti. Masu maisa tik ilgi, kamēr visas sastāvdalas ir vienmērīgi izmaisìtas. Gatavojot pīrādziṇus ar iekārtas palīdzību, tā tvertnē ievieto sagatavoto mīklu un atsevišḳi malto gạlu, un automāts pats formē un apcep pirādziṇus.

Apceptus un ceptus izstrādājumus atdzesē uz sastatnu plauktiem līdz to temperatūra nepārsniedz $20^{\circ} \mathrm{C}$, iepako un nosūta uz realizāciju. 
4. tabula. Maltās galas receptes pīrāgu (kulebjaku un grozinu) pildijumiem (kilogramos/100 kg pildijuma)

\begin{tabular}{||l|c|c|c|c||}
\hline \multicolumn{1}{|c|}{ Sastāvdalas } & $\begin{array}{c}1 . \\
\text { variants }\end{array}$ & $\begin{array}{c}2 . \\
\text { variants }\end{array}$ & $\begin{array}{c}3 . \\
\text { variants }\end{array}$ & $\begin{array}{c}4 . \\
\text { variants }\end{array}$ \\
\hline Bāzes brētliṇu maltā gal̆a & 60 & 65 & 70 & 50 \\
\hline Dārza sīpoli & - & 15 & - & 17 \\
\hline Puravi/lociṇi & 15 & - & - & - \\
\hline Vārītas olas & 22 & - & - & 15 \\
\hline Vārīti rīsi & - & - & - & 15 \\
\hline Blanšēti spināti & - & 17 & - & - \\
\hline Garšvielu maisījums 1 & 2 & - & 2 & - \\
\hline Garšvielu maisījums 2 & - & 2 & - & 2 \\
\hline Pārtikas sāls & 1 & 1 & 1 & 1 \\
\hline Apcepti dārzen,i & - & - & 27 & - \\
\hline Krāsviela „Paprika» & 0,05 & 0,05 & 0,06 & 0,06 \\
\hline \hline
\end{tabular}

Prakse ir parādījusi, ka, ražojot mīklas izstrādājumus ar zivju malto galu, nevajadzētu pielietot škidrās garšas un aromatizējošās piedevas, piemēram, zivju, garnelıu, krabju u.c. aromātus. Cepšanas laikā cepeškrāsnī notiek grūti paredzamas garšas un aromāta kompozīcijas izmainas, kas izsauc nepatīkamas kīimiskas piegaršas rašanos

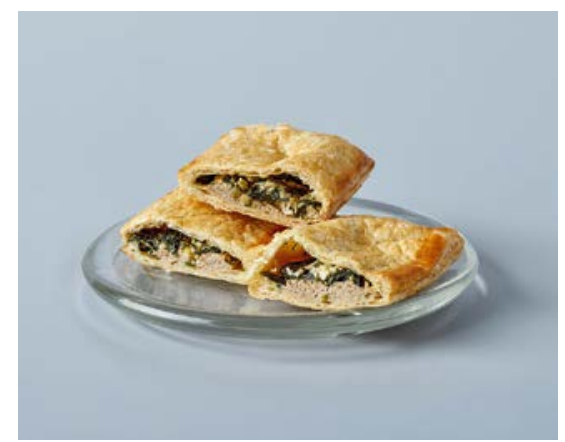

19. attēls. Zivju miltu kulinārija - kuḷebjaka ar sieru

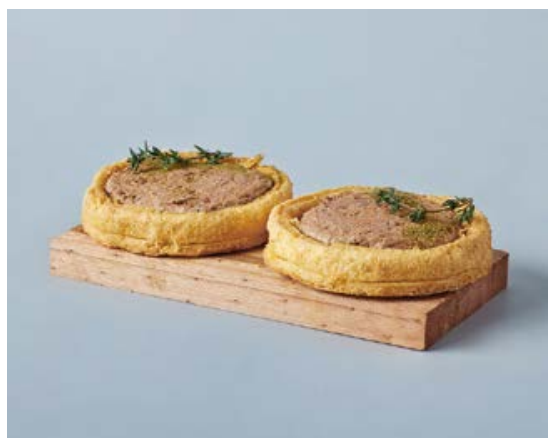

20. attēls. Zivju miltu kulinārija - „vol-au-vent» no kārtainās mīklas

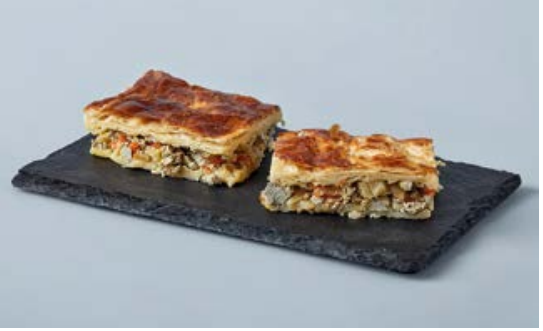

21. attēls. Zivju miltu kulinārija - zivju pīrāgi

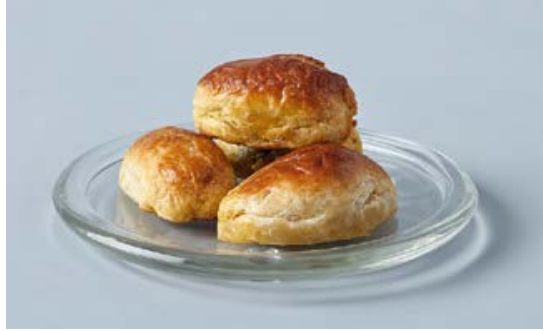

22. attēls. Zivju miltu kulinārija - pīrādziṇi ar zivīm

\subsection{KULINĀRIJAS IZSTRĀDĀJUMI NO ZIVJU} MALTĀS GALAS - PILDİTA ZIVS, „GEFÜLLTE FISCH», FORŠMAKS, ZIVJU TEFTELI UN FRIKADELES AR

UZLËJUMIEM UN MËRCËM, TERİNES

Tādus èdienus kā pildìtas zivis, terīnes un „gefilte fisch» reti gatavo mājās, jo to gatavošana ir saistīta ar ilgstošu un skrupulozu saldūdens zivju - karpu vai līdaku kulināro apstrādi. Tādēl šādus èdienus parasti pasūta restorānos un tie maksā dārai. Ražojot šādus pašus produktus no bāzes brētliṇu maltās galas, galvenā ražošanas problēma ir nepieciešamā produkta precīza garšas un aromāta kompozícijas dozēšana - no tirgū piedāvātajām pārtikas piedevām ir jāizvēlas vēlamais „karpas aromāts», „zandarta aromāts» vai "līdakas aromāts». Latvijas apstāklos šo zivju maltās gaḷas esamība lauj iztikt bez dārgām pārtikas piedevām.

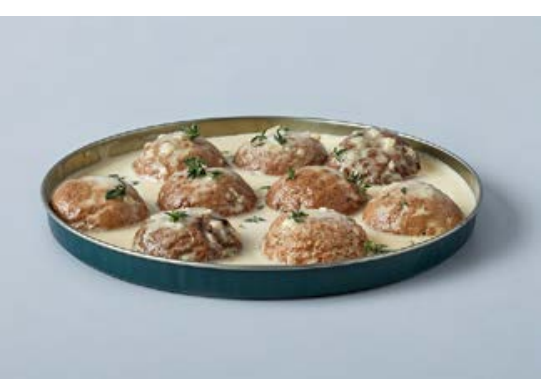

23. attēls. Zivju maltās galas kulinārijas izstrādājumi - zivju tefteli ar mērci

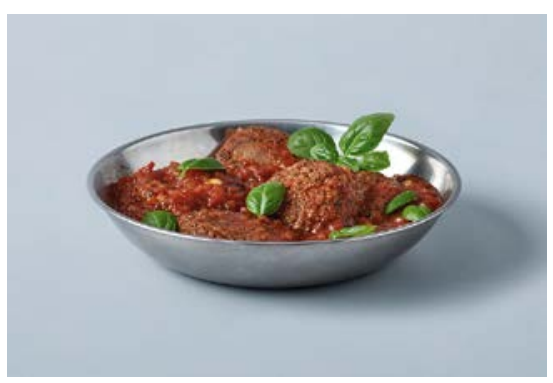

24. attēls. Zivju maltās galas kulinārijas izstrādājumi - zivju frikadeles ar mērci 


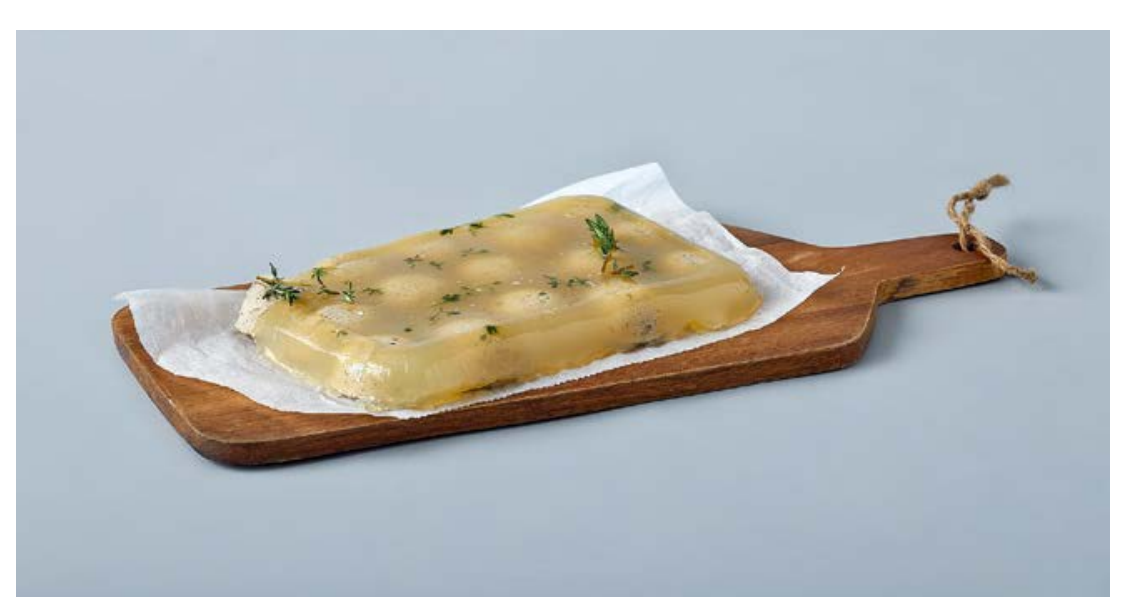

25. attēls. Zivju maltās galas kulinārijas izstrādājumi zivju tefteli želejā

Terīnu ražošanas tehnoloǵija ir mazāk sarežğita - šo produktu formē no brētliṇu maltās galas ar pievienotiem dārzeniem, bet virspusē ugunsizturīgajā formā ielej želejveidojošu aspiku. Pēc tam terīni cep cepeškrāsnī līdzīgi kā sacepumu, termiskās apstrādes laiks ir atkarīgs no formas dziluma un terīnes masas biezuma.

"Gefillte fisch» jeb pildītās zivs pagatavošana no bāzes brētliṇu maltās gạlas ir daudz vienkāršāka par klasisko. Tā kā brētliṇu maltajai galai ir neitrāla zivju garša, tai ir jāpievieno izvēlētā garšas un aromāta kompozīcija (klasiskajā produktā tas, attiecīgi, būs karpas un līdakas aromāts), pienā mērcēti sausini, olas un garšvielas, pēc tam jāsaformē nelielās porcijās, kuras var sasaldēt gan realizācijai mazumtirdzniecības, gan HoReCa tīklā.

Bāzes brētliṇu maltā gạla ir laba izejviela zivju frikadelı un zivju teftelu ražošanai. Frikadelu izgatavošanai var izmantot bāzes malto galı bez izmaiṇām - n,emot vērā tās neitrālo zivju garšu un labi saistīto struktūru, nekādas izmainas receptē nav nepieciešamas. Ražojot teftelus, bāzes maltajā gaḷa pievieno garšvielas, vārītus rīsus un tos pasniedz želejā. Želeja var būt dažāda veida un ir atkarīga no ražotāja izvēles. Kà tika noskaidrots šĩ projekta ietvaros, veicot frikadelu degustāciju, potenciālie patērētāji augsti novērtēja ar zivīm kontrastējošās garšas - brūklenu uzlējumu un želejveida tomātu mērci.
5. tabula. Maltās galas recepte terīnu, Gefüllte fisch un pildìtas zivs (kilogramos/100 kg produkta)

\begin{tabular}{|c|c|c|c|c|c|c|}
\hline Sastāvdaḷas & $\begin{array}{l}\text { Gefüllte } \\
\text { fisch }\end{array}$ & $\begin{array}{l}\text { Pildita } \\
\text { zivs }\end{array}$ & $\begin{array}{c}\text { Terīne } \\
\text { ar } \\
\text { vasabi }\end{array}$ & $\begin{array}{l}\text { Terīne } \\
\text { "Tom } \\
\text { Yum» }\end{array}$ & $\begin{array}{l}\text { Tefteli } \\
\text { ar } \\
\text { rīsiem }\end{array}$ & $\begin{array}{c}\text { Frikade- } \\
\text { les }\end{array}$ \\
\hline $\begin{array}{c}\text { Bāzes brētliṇu } \\
\text { maltā gala }\end{array}$ & 71 & 70 & 87 & 80 & 65 & 97,5 \\
\hline $\begin{array}{c}\text { Sojas mērce ar } \\
\text { vasabi }\end{array}$ & - & - & 2,3 & - & - & - \\
\hline $\begin{array}{c}\text { Mērce } \\
\text { „Tom Yum» }\end{array}$ & - & - & - & 3,3 & - & - \\
\hline Dārza sīpoli & 5 & 8 & - & - & 7 & - \\
\hline $\begin{array}{c}\text { Baltmaizes } \\
\text { sausiṇi }\end{array}$ & 6 & 6 & - & - & - & - \\
\hline Vārìta ola & 6 & 6 & - & 4 & - & - \\
\hline Piens & 4 & 5 & - & - & - & - \\
\hline Vārīti rīsi & - & - & 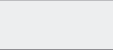 & & 25 & - \\
\hline $\begin{array}{l}\text { Garšvielu } \\
\text { maisījums } 1\end{array}$ & 2 & - & - & 2 & - & 1,5 \\
\hline $\begin{array}{c}\text { Garšvielu } \\
\text { maisijums } 2\end{array}$ & - & 1,5 & 2 & - & 2 & - \\
\hline Karpas aromāts & 0,3 & - & - & - & - & - \\
\hline Lìdakas aromāts & - & 0,5 & - & - & - & - \\
\hline Pikantais aspiks & 2 & 2 & 2 & 2 & 2 & - \\
\hline Blanšēti burkāni & 3 & - & - & - & - & - \\
\hline Pārtikas sāls & 1 & 1 & 0,7 & 0,7 & 1 & 1 \\
\hline Apcepti dārzeṇi & - & - & 6 & 8 & - & - \\
\hline $\begin{array}{l}\text { Krāsviela } \\
\text { „Paprika» }\end{array}$ & 0,05 & 0,05 & 0,05 & 0,06 & - & - \\
\hline
\end{tabular}

\subsection{ZIVJU EMULGËTIE DESU IZSTRĀDĀJUMI -} VĀRITTAS ZIVJU DESAS, CIISINI, SARDELES

Zivju emulǵéto desu izstrādājumu ražošana, izmantojot brētliṇu bāzes malto galı, ir saistīta ar vērā n,emamām grūtībām. Brētliṇu maltā gala satur nelielu (līdz 17\%) olbaltumvielu daudzumu, 
maksimāli zemu kolagēna un nenozīmīgu tauku daudzumu. Lai ražotu zivju desu izstrādājumus ar klasiskiem parametru (organoleptiskajiem) rādītājiem - gaiši rozā krāsu, viendabīgi blīvu konsistenci un sabalansētu garšu, ir jāizmanto pārtikas piedevas un rūpīgi jāizvēlas desu apvalks.

Zivju pārstrādes uzṇēmumos nav iespējas atsevišk,i no zivju izejvielām uzglabāt dzivnnieku izcelsmes izejvielas ar lielu tauku un kolagēna saturu. Šîs sastāvdalas ieteicams aizvietot ar augu ellu un dzîvnieku izcelsmes olbaltumvielām.

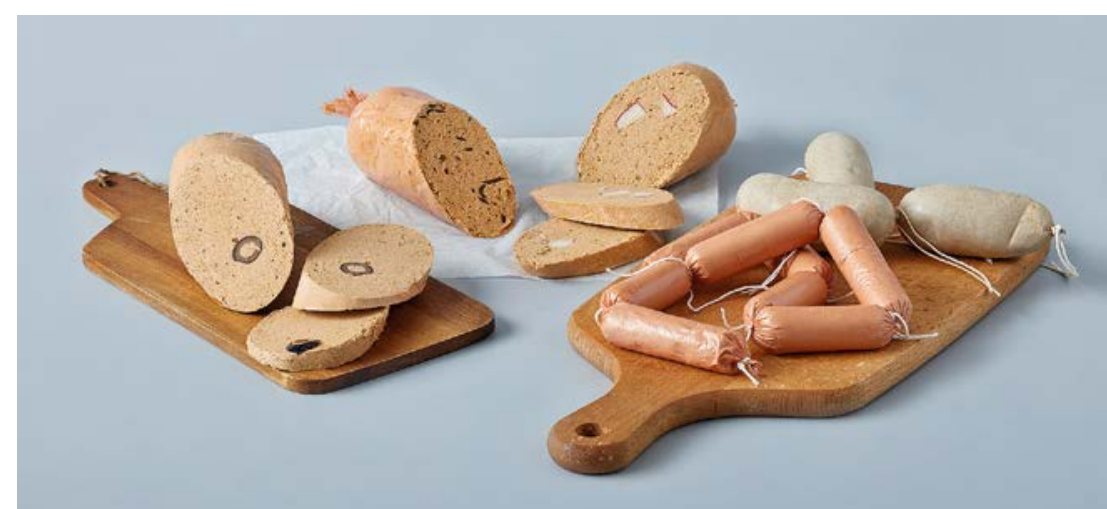

26. attēls. Zivju emulǵétie desu izstrādājumi - vāritas zivju desas, cisinini, sardeles

Vārītajām zivju desām un cīsiniem vislabāk piemēroti ūdens un gaisa necaurlaidīgie poliamīda apvalki ar piepildījuma koeficientu līdz 110\%. Ražojot šādas desas, maltajai galai pēc iepildišanas obligāti ir jālauj noblīvēties, lai pievienotās sastāvdalas veidotu emulsiju, kas termiskās apstrādes laikā būtu stabila.

6. tabula. Vãrītu zivju desu receptes ( $\mathrm{kg} / 100 \mathrm{~kg})$

\begin{tabular}{||c|c|c|c||}
\hline \hline Sastāvdaḷas & Vārīta desa & Zivju cīsiṇi & Zivju sardeles \\
\hline Bāzes maltā gaḷa & 43,53 & 56,9 & 55,33 \\
\hline Augu ellıa & 10,9 & 14,22 & 13,83 \\
\hline Sojas izolāts & 4,35 & 5,7 & 5,53 \\
\hline Ūdens & 21,8 & 5,7 & 8,3 \\
\hline
\end{tabular}

\begin{tabular}{||c|c|c|c||}
\hline \hline Sastāvdaḷas & Vārīta desa & Zivju cīsiṇi & Zivju sardeles \\
\hline Garšviela 1 & 1,52 & - & - \\
\hline Garšviela 2 & - & 2 & - \\
\hline Garšviela 3 & - & - & 1,94 \\
\hline Dārza sīpoli & 1,9 & 5,7 & 5,53 \\
\hline Stabilizators 1 & 0,87 & - & - \\
\hline Stabilizators 2 & - & 1,71 & - \\
\hline Stabilizators 3 & - & - & 1,66 \\
\hline $\begin{array}{c}\text { Dzīvnieku izcel- } \\
\text { smes olbaltums }\end{array}$ & 5,44 & 7,11 & 6,92 \\
\hline Pãrtikas sāls & 0,76 & 1 & 1 \\
\hline \hline
\end{tabular}

Pēc vārīšanas šādas desas noteikti ir jāatdzesē, iegremdējot tās ledainā ūdenī $\left(2-4^{\circ} \mathrm{C}\right)$ vai apstrādājot ar ūdens dušu. Degustācija (lietošana uzturā) jāveic ne ātrāk kā 12 stundas pēc atdzesēšanas, kad zivju desas emulsija ir pilnībā nostabilizējusies.

Tehnoloǵija lauj ražot plašu zivju desu sortimentu ar dažādu „rakstu» - kontrastējošiem, neviendabīgiem ieslēgumiem, kas izcelas uz desas pamatmasas fona. Loti pievilcīgi izskatās vārîtas zivju desas ar olīvu, krabju nūjiṇu un jūras kāpostu ieslēgumiem.

\subsection{SALDĒTI ZIVJU MILTU IZSTRĀDĀJUMI - ZIVJU MAKARONU IZSTRĀDĀJUMI UN \\ ZIVJU PASTA, RAVIOLI}

Zivju miltu izstrādājumiem piemît interesants ārējais izskats un organoleptiskie kvalitātes rādītāji, tiem ir izteikta zivju garša, uzlabota bioloǵiskā un uzturvērtība, pazemināti enerǵētiskās vērtības rādītāji un tiktos var pieskaitit pie diētiskiem produktiem. Pasta tika iegūta, izmantojot mīklas maisī̌anas iekārtu ar 25\% bāzes brētlinu maltās gallas pievienošanu. Lielāka maltās galas daudzuma pievienošana izraisija mīklas vijīguma zudumu un makaronu izstrādājumu sliktu formējamību. Pastas krāsa tika iegūta, pievienojot mīklai spinātus (zalai krāsai) un paprikas ekstraktu (oranžajiem un dzeltenajiem toniem) 


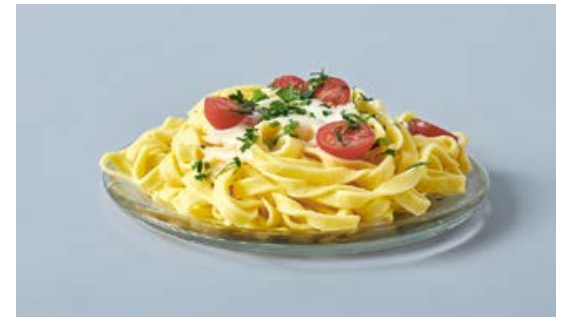

27. attēls. Saldēti zivju miltu izstrādājumi - zivju pasta ar pievienotu paprikas ekstraktu kā pildijums tika izvēlēts kazas siers ar kimenēm (Jānu siers). Mīklas/ pildijuma attieciba - 70/30

7. tabula. Zivju miltu izstrādājumu receptes (kg/10 kg)

\begin{tabular}{||c|c|c|c||}
\hline Sastāvdaḷas & Zạāa pasta & Oranžā pasta & Ravioli \\
\hline Bāzes maltā gąla & 25 & 25 & 25 \\
\hline Sojas izolāts & 1,5 & 1,5 & 1,5 \\
\hline Ũdens & 37 & 36 & 37 \\
\hline Svaigi spināti & 2,5 & - & 2,5 \\
\hline Paprika & - & 0,05 & - \\
\hline Garšviela 1 & 1,5 & - & 2 \\
\hline Garšviela 2 & - & 2 & - \\
\hline Garšviela 3 & - & - & - \\
\hline Pãrtikas sāls & 0,5 & 1 & 0,5 \\
\hline Kviešu milti & 30 & 33 & 30 \\
\hline Premikss 1 & 2 & - & - \\
\hline Premikss 2 & - & 1,5 & - \\
\hline Premikss 3 & - & - & 1,5 \\
\hline
\end{tabular}

Bāzes brētlinu maltā gala a, kas ir smalki sasmalcināta un viendabìga masa, var kalpot par delikatešu pastu, pastēšu, zivju sviestu un sviestmaižu krēmu pamatu.

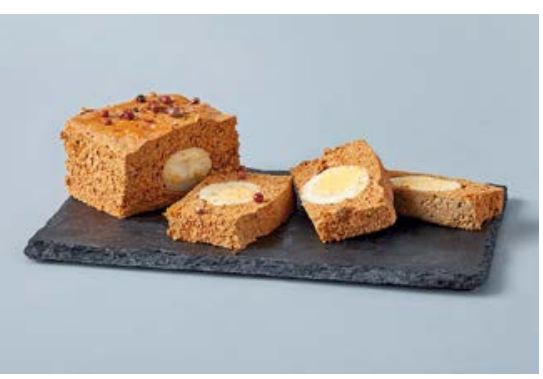

29. attēls. Emulǵéti zivju izstrādājumi - pastēte ar olu

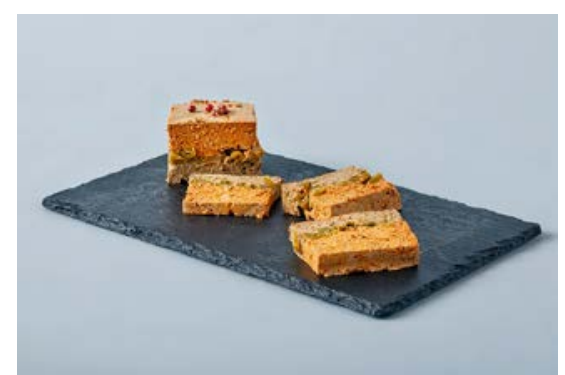

31. attēls. Emulǵéti zivju izstrādājumi - pastēte ar olīvām

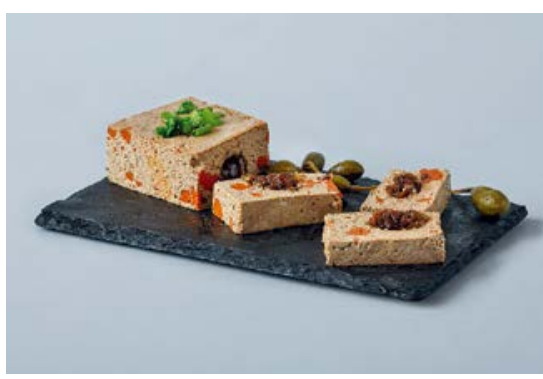

30. attēls. Emulǵéti zivju izstrādājumi - brētlinu masas pastēte

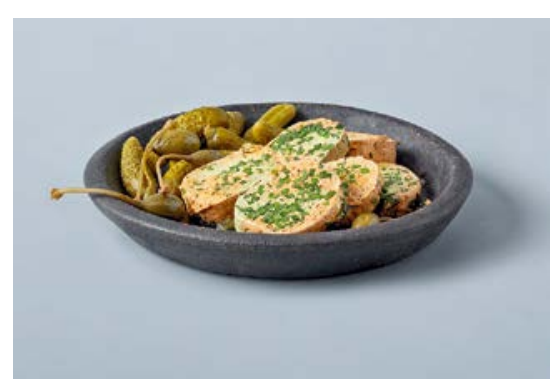

32. attēls. Saldēti zivju mīklas izstrādājumi sviestmaižu masa
Lai iegūtu zivju sviestu un zivju pastu, tiek izmantota bāzes brētliṇu maltā gala ar pievienotu saldo krējumu (margarīnu), majonēzi, galda sinepēm un nātrija benzoātu (nav obligāti, to pievieno, lai pagarinātu produkta uzglabāšanas terminu). Produktu ir ieteicams gatavot, izmantojot kuteri, kas nodrošina nepieciešamo sasmalcināšanas pakāpi un sastāvdalı emulǵéšanu. 
8. tabula. Uz brētlinu maltās galas bāzes izgatavotu zivju pastu un sviestu receptes $(\mathrm{kg} / 100 \mathrm{~kg})$

\begin{tabular}{|c|c|c|c|}
\hline Sastāvdaḷas & Zivju sviests & Zivju pasta 1 & Zivju pasta 2 \\
\hline Bāzes brētliṇu maltā gala & 45 & 90 & 50 \\
\hline Saldkrējuma sviests & 46 & - & - \\
\hline Saldkrējuma margarīns & - & 7 & 23 \\
\hline Majonēze & 6 & - & - \\
\hline Galda sinepes & - & 1 & - \\
\hline Garšviela 1 & 2 & - & - \\
\hline Garšviela 2 & - & 2 & - \\
\hline Garšviela 3 & - & - & 1 \\
\hline Emulgators & 1 & - & 1 \\
\hline Marinēti sīpoli & - & - & 15 \\
\hline Sīpolu etik̦a marināde & - & - & 10 \\
\hline
\end{tabular}

Lai garantētu ciešu ūdenī un taukos škīstošo sastāvdalu sasaisti stabilā emulsijā, tika izmantoti emulgatori uz dabīgā lecitīna bāzes.

\section{NO BRĒTLINĀM IZGATAVOTAS MALTĀS GAL̦AS PRODUKTU RAŽOŠANAS EKONOMIKA UN ORGANIZĀCIJA}

\subsection{ZIVJU APSTRĀDES MŪSDIENU TENDENCES}

èl nesenā pagātnē zivju pārstrāde galvenokārt sastāvēja no zivju uzglabāšanas pēc nozvejas ar mākslīga aukstuma izmantošanu, žāvēšanas/kaltēšanas, sālīšanas un konservēšanas. Zivju uzglabāšanas paṇēmieni noteica arī zivju produktu patērētāju kulinārās īpašības. Konservēšana paplašināja zivju izstrādājumu sortimentu (konservi un preservi) un to derīguma termin,us, taču ievērojami pazemināja zivju uzturvērtību, pasliktināja organoleptiskos rādītājus, būtiski palielināja darbietilpīgumu un zivju produkcijas izmaksas.

No otras puses, lai arī patērētāju vidū eksistē tradicionāls pieprasījums pēc svaigām/atdzesētām zivīm, kas spēj arī tās pagatavot mājas virtuvē, zivju produktu patērin,š tāpat samazinās. Tas ir saistīts gan ar to, ka nepieaug jaunu patērētāju skaits, gan ar brīvā laika struktūras būtiskām izmainām, jo īpaši jaunāku ǵimen,u vidū.

Arī ražotāji sastopas ar dažādām grūtībām, kas rada problēmas pieprasījuma pēc svaigām/atdzesētām zivīm apmierināšanā:

- reti izdodas nodrošināt dzīvu vai svaigu zivju ātru piegādi līdz gala patērētājam, ja netiek ieviesti papildu bojāšanās novēršanas pasākumi;

- loǵistikā esošās aukstuma kameras var radīt temperatūras svārstību risku atdzesētu zivju uzglabāšanas laikā, kas palielina produktu sabojāšanās risku;

- augstā fermentu aktivitāte zivju iekšējos orgānos ievērojami sarežǵī atdzesētu nekidātu zivju uzglabāšanu, bet kidašana var izraisìt patogēno un pūšánu veicinošo mikroorganismú attīstību iekšējos audos, kas samazina uzglabāšanas terminus;

- ātrai/šoka zivju sasaldēšanai ir nepieciešams dārgs, moderns aprīkojums un augsta ražošanas kultūra, kas, savukārt, palielina gatavo produktu pašizmaksu, kā arī patērētāji labāk iegādājas svaigas 
zivis, jo tiem ir zināmi aizspriedumi attiecībā uz saldētām zivīm (.„produkts nabadzīgajiem»);

- tradicionāla/lēna zivju sasaldēšana samazina to bioloǵisko un uzturvērtību, kā arī organoleptiskos rādītājus: šādām zivīm ir bālāki muskulaudi, irdena un ūden,aina struktūra, atkausējot ir novērojami lieli masas zudumi un olbaltumvielu struktūra ir neatgriezeniski pasliktinājusies. No šādām zivīm gatavotu ēdienu kvalitāte ir krietni zemāka par no svaigām vai atdzesētām zivīm pagatavotu ēdienu kvalitāti;

- nekontrolēts un nesakārtots zivju piegādes un izplatīšanas process rada pamatu dažādām launprātīgām darbībām.

Tādējādi zivju pārstrāde pašlaik atrodas nepietiekami attīstītā stāvoklī, un būtu jāizskata iespējas šo situāciju mainīt uz labo pusi.

Lai palielinātu zivju pārstrādes uznēmumu ražošanas rentabilitāti, ir jāievieš pilnīgākas un dziḷākas zivju izejvielu pārstrādes prakses, līdzīgi kā tas tiek darīts galas apstrādē.

Galas pārstrādes nozarē ir grūti iedomāties situāciju, kad nozare nodarbojas tikai ar govju sadalīšanu steikos, nosūtot visas atlikušās neapstrādātās galas izejvielas lopbarības vajadzībām vai utilizācijai. Tajā pašā laikā šāda situācija, protams, atbilstoši specifikai, pastāv jūras velšu pārstrādē. Nemot vērā pasaulē pastāvošo un pieaugošo uztura olbaltumvielu deficītu, visas pieejamās zivju un jūras velšu olbaltumvielas būtu jāizmanto pārtikas vajadzībām, un zivju pārstrādes rūpniecības uzdevums ir izstrādāt ražošanā izdevīgus, pilnvērtīgus, garšīgus un daudzveidīgus pārtikas produktus.

Kādā veidā var realizēt iepriekš neizmantotu vai mazvērtīgu pārtikas izejvielu ieklaušanu pārtikas apritēe Būtu jāizmanto zivju izejvielu malšana un jārada pārstrukturēti maltās gaḷas produkti ar dažādām pildvielām un piedevām, kas modificēe zivju maltās gaḷas izejvielas vēlamajā virzienā

Maltās galas ražošanai un tās pārstrādes tehnoloǵijas attīstībai jāizvēlas galvenā zivju izejviela, jo dažādu zivju sugu audi būtisk atškiras pēc sastāva, uzturvērtības, ēdamo, neēdamo un nosacìti èdámo dalı skaita un attiecības, kā arī olbaltumvielu, lipīdu un mitruma attiecības.

Ir svarīgs zivju izejvielu izmaksu faktors, jo dārou zivju izmantošanas gadījumā pārstrādātājs var būt apmierināts ar peḷnas normu no veselu, kidātu vai filejās sadalītu zivju pārdošanas. Šajā gadijumà šādu zivju vai to atlikumu papildu pārstrāde maltajā galā var izrādìties nerentabla vai ar zemu rentabilitāti, jo būs nepieciešami ieguldijum aprīkojumā, tehnoloǵijas pilnveidošanā un jaunās produkcijas pārdošanas apjomu paplašināšanā.

Jo īpaši tas būs novērojams lielu un vidēju zivju gadījumā, kuras ir vieglāk sagriezt dāroās filejās un salīdzinoši neliela daudzuma nosacìti ēdamās un neēdamās dalās. Šajās dalās var izrādìties pārāk mazs pārtikas nolūkiem piemērotú audu daudzums.

Tādēl pārstrādei maltās galas produktos būtu jāizmanto sīko sugu zivis sekojošu iemeslu dēl:

- šādas zivis dzīvo baros un tiek zvejotas rūpnieciskos apjomos;

- vienā lomā nozvejotu zivju biokīmiskās atškirības ir nenozīmīgas, parasti tās ir līdzīga vecuma, ar līdzīgu tauku un olbaltumvielu saturu, arī lipīdu un ūdens attiecība tajās ir praktiski vienāda;

- sīku sugu zivju cena parasti ir ievērojami zemāka par lielo sugu zivju cenu, tādẹl to apstrāde ražošanai ir daudz noderīgāka, jo paaugstina pievienoto vērtību;

- maltās galas pagatavošana no sīkām zivīm ir ievērojami mazāk darbietilpīga, jo tās var smalcināt veselas, bez iepriekšējas sadalīšanas muskulaudos un kaulaudos. Šādu zivju asakas ir smalkākas un, pienācīgi sasmalcinot, nav jāatdala.

\subsection{MALTĀS GALAS RAŽOŠANAS NO MAZIZMËRA ZIVİM HACCP}

HACCP sistēmu zivju pārstrādes ražošanai izstrādā, nemot vērā sekojošus galvenos principus:

1. Risku analīze (potenciālo risku identifikācija un to novērtējums) visās produkta „dzīves cikla» stadijās - sākot ar izejvielu pien,emšanu (augu vai dzīvnieku audzēšanu) līdz galapatērētājam, ieskaitot pārstrādes, uzglabāšanas un realizācijas posmus.

2. Ražošanas kritisko kontrolpunktu (KKP) identificēšana, lai novērstu (minimizētu) riskus vai to iespējamo parādīšanos. Turklāt aplūkojamās pārtikas produktu ražošanas operācijas var aptvert izejvielu piegādi, pārstrādi, uzglabāšanu, transportēšanu, uzglabāšanu noliktavās un produkcijas realizāciju. 
3. KKP kritisko robežu noteikšana (novērojamo un mērāmo parametru galējās vērtības).

4. Monitoringa sistēmas, kas lautu veikt KKP kontroli, pamatojoties uz plānotajiem pasākumiem un novērojumiem, izstrāde, lai nodrošinātu atbilstību noteiktajām kritiskajām robežām.

5. Korekciju un koriǵējošu darbību izstrāde to pielietošanai gadījumos, ja tiek konstatētas novirzes no kritiskajām robežām.

6. Verifikācijas procedūru izstrāde un pielietošana (uzturēšana) ar mērki apstiprināt HACCP sistēmas funkcionēšanas rezultativitāti.

7. HACCP sistēmas procedūru dokumentēšana un ierakstu veikšana, kas nepieciešami atbilstoši HACCP sistēmas procedūrām.

\subsection{GALVENO KRITISKO KONTROLPUNKTU (KKP) NOTEIKŠANA, RAŽOJOT MALTO GALU NO MAZIZMËRA ZIVĪM}

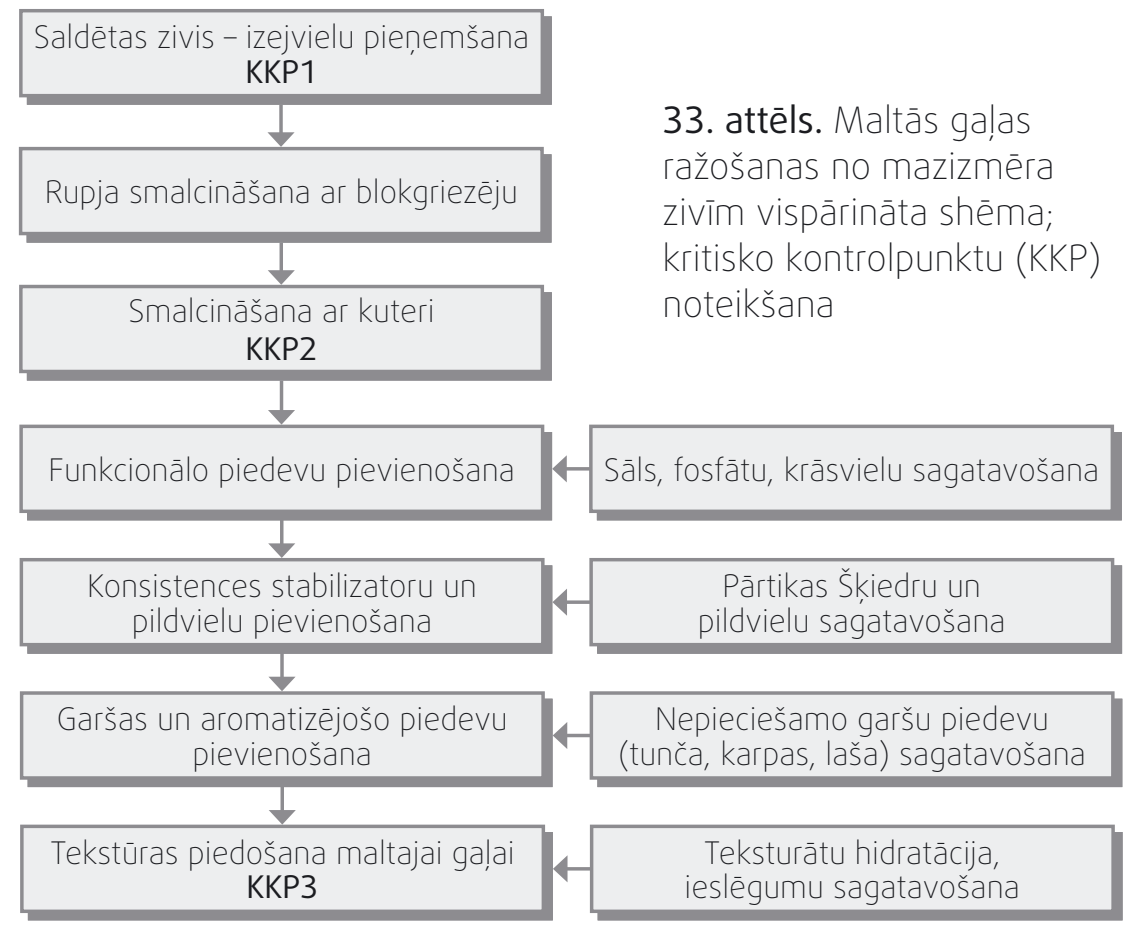

1 - Izejvielu (saldētu zivju bloku) pienemšana ir KKP1.
Pirms nosūtī̌anas uz ražošanu ir jāveic iespējama atkušanas pazīmju kontrole. Nepareizas uzglabāšanas un saldēšanas procesa izjaukšanas rezultātā atseviški bloki vai veselas zivju partijas var būt pilnībā vai dalêji atkausētas, kas palielina šādu zivju kā tehnoloǵisko izejvielu bojāšanās risku.

Kontroles metode - bloku ǵeometrijas vizuāla pārbaude (šḳautnes nedrīkst būs nodrupušas, visiem lenkịiem jābūt taisniem un pareiziem), atsevišk, bloki nedrīkst būt savā starpā pārāk salipuši, ledus necaurspīdīguma pārbaude starp atseviškiem zivju liemen,iem (pēc ātrās sasaldēšanas ledus ir dulk,kains un necaurspīdīgs, bet pēc lēnas sasaldēšanas vai, ja ir notikusi atkušana, ledus ir caurspīdīgs)

Izejvielu enerǵētiskās un uzturvērtības pārbaude - enerǵētiskā vērtība, olbaltumvielu, lipīdu un mitruma procentuālais saturs. Kontroles metodes:

- mitruma daudzuma noteikšana - ar termogrāfisko metodi;

- olbaltumvielu daudzuma noteikšana - ar automātiskajām titrēšanas iekārtām;

- lipīdu daudzuma noteikšana - ar automātiskajām iekārtām;

- enerǵētiskās vērtības noteikšana - ar automātisko kalorimetru.

Zivju mitruma noturēšanas spējas pārbaude, lai aprēkinātu pievienojamo piedevu daudzumu - ar centrifugēšanas metodi.

2 - rupja smalcināšana ar blokgriezēju, bloki ir jāsacērt, nevis jāsaspiež. Kontroles metode - saldētu zivju mazo kubiku šk,autṇu pareizības vizuāla pārbaude, tiem jābūt bez atkušanas pēdām.

3 - izejvielu piegāde no blokgriezēja uz kuteri ar automātiskā lentveida transportiera palīdzību. Izejvielām ir jābūt izolētām no apkārtējās vides piesārnojumiem, transportēšanas laikā brētliṇas nedrïkst atkust.

4 - rupja smalcināšana kuterī ir KKP2. Šajā punktā ir jāveic sekojošu parametru kontrole: 
- Kutera nažu asums - kutera nažiem notrulinoties, smalcināšana aizṇem vairāk laika, brētlin,u maltā gaḷ vairāk sasilst un vairāk reaǵē ar gaisu, paaugstinātā temperatūra paātrina bojāšanos. Kontroles metode - regulāra nažu asināšana uz speciāla asināšanas darbagalda.

- Pareizs nažu regulējums attiecībā pret kutera kausu - ja starp nažiem un kutera kausu paliek brīva vieta, kurā nenotiek zivju smalcināšana, tiek veicināta maltās gaḷs neviendabīguma rašanās un organoleptisko rādītāju pazemināšanās. Kontroles metode - mikrometrs, speciāls inženiermehāniḳu aprīkojums.

- Nepietiekams vakuums kuterī vai tā neesamība - izsauc maltās galas mikrobioloǵisko piesārn,ošanos, lipīdu paātrinātu oksidāciju, maltās galas krāsas pasliktināšanos, paaugstinātu krāsvielu patērin,u. Kontroles metode - iebūvēts kutera manometrs.

\section{5 - funkcionālo piedevu pievienošana.}

- Pareiza piedevu pievienošanas secība kuterī sasmalcinātām zivīm. Nepareizā secībā pievienotas piedevas var radīt brāḳi. Kontroles metode - kutera operatora apmācība, tehnologam no savas puses jāveic pievienošanas secības kontrole.

- Pareizs sastāvdalı dozējums - lai ievērotu receptēs paredzētos izejvielu daudzumus. Kontroles metode - savlaicīga svēršanas aprīkojuma pārbaude.

\section{6 - konsistences stabilizatoru un pildvielu pievienošana.}

- Pareiza piedevu pievienošanas secība kuterī sasmalcinātām zivīm. Nepareizā secībā pievienotas piedevas var radīt brāḳi. Kontroles metode - kutera operatora apmācība, tehnologam no savas puses jāveic pievienošanas secības kontrole.

- Pareizs sastāvdalı dozējums - lai ievērotu receptēs paredzētos izejvielu daudzumus. Kontroles metode - savlaicīga svēršanas aprīkojuma pārbaude.

7 - Garšas un aromatizējošo piedevu pievienošana

- Pareiza piedevu pievienošanas secība kuterī sasmalcinātām brētlinām.
Nepareizā secībā pievienotas piedevas var radīt brāki. Kontroles metode - kutera operatora apmācība, tehnologam no savas puses jāveic pievienošanas secības kontrole.

- Pareizs sastāvdalı dozējums - lai ievērotu receptēs paredzētos izejvielu daudzumus. Kontroles metode - savlaicīga svēršanas aprīkojuma pārbaude.

8 - tekstūras piešḳiršana maltajai galai ir KKP3.

- to veic smalki sasmalcinot zivju izejvielas un pievienojot teksturātus. Kontroles metode - vizuālā un taktilā brētliṇu sasmalcināšanas ar kuteri pakāpes noteikšana, savlaicīga hidratēto teksturātu pievienošana (jākontrolē hidratācijas laiks - ne vairāk kā 5 minūtes).

Tā kā šis ir maltās gaḷs ražošanas noslēdzošais posms, šajā kritiskajā kontroles punktā ir svarīga temperatūras kontrole kuterēšanas laikā - nav piel̦aujama maltās gaḷs temperatūras paaugstināšanās kuterēšanas laikā virs $0^{\circ} \mathrm{C}$. Kontroles metode - tehnoloǵiskais termometrs vai kuterī iebūvēts termometrs.

Pareizā maltās gaḷas krāsa - atbilstoša izvēlētajai gatavo produktu līnijai. Kontroles metode - salīdzināšana ar kontrolton,u katalogu.

Produkta viskozitāte - ietekmē maltās gaḷas produktu organoleptiskos rādītājus un tās veidojamību. Kontroles metode - rotācijas viskozimetrs ar viskozitātes rādījumiem 6,0 - 8,5 Pa·s robežās.

9 - sastāvdalu sagatavošana prasa regulāras svēršanas aprīkojuma pārbaudes, pastāvīgas sastāvdaḷ dozētāju instruktāžas. Svaru telpā jāuztur temperatūra līdz $+18{ }^{\circ} \mathrm{C}$ un relatĩvais mitrums ne augstāks kā 60\%.

10 - apkārtējās vides parametri.

- Gaisa temperatūra cehos - paaugstināta gaisa temperatūra paātrina zivju mikrobioloǵisko, fermentatīvo un oksidatīvo bojāšanos, tādēl ir jākontrolē temperatūra telpās, uzturot to ne augstāku kà $+12{ }^{\circ} \mathrm{C}$. Kontroles metode - automatizētā gaisa kondicionēšanas sistēma ar uzdoto parametru uzturēšanu. 
- Gaisa relatīvais mitrums cehos ir iztvaicētāa ūdens daudzuma attiecība pret kondensētā ūdens daudzumu. Paaugstinoties mitrumam ražošanas telpās, pieaug zivju izejvielu, palīgmateriālu un gatavo produktu mikrobioloǵiskās bojāšanās risks. Relatīvā mitruma rādìtāju novirzes no ieteicamajiem rāditājiem gadijumā mainās maltās gaḷas adhēzijas pie maltās gaḷas izstrādājumu formēšanas caurulvadiem un aprīkojuma virsmām rādîtāji, kas palielina klūdu iespējamību, pievienojot maltajai galai piedevas (palielinātas maltās gaḷas adhēzijas pie virsmām dēl nepieredzējuši aprīkojuma operatori var ieviest nevajadzīgas recepšu izmaiṇas, lai arī bieži vien problēmas rada paaugstināts gaisa mitrums). Kontroles metode - automatizēta gaisa kondicionēšanas sistēma ar uzdoto parametru uzturēšanu.

- Bakteriālā gaisa un darba virsmu piesārṇotība ražošanas telpās - pārtikas produktu un izejvielu klātbūtne veicina mikroorganismu attīstību. Lai samazinātu to daudzumu, ir jāuzstāda ultravioletās gaismas lampas virs ceha svarīgākajām vietām un ne retāk kà 4 reizes diennaktī uz 15 minūtēm jādezinficē gaiss un virsmas. Ne retāk kā reizi diennaktī jāapstrādā darba virsmas un aprīkojums ar baktericīdiem lìdzekliliem. Kontroles metode - automātiska ultravioleto lampu ieslēgšanās noteiktā laikā.

- Sanitārās problēmas, kas saistītas ar personālu - darbiniekiem ir jāvalkā specapǵērbs, regulāri jānodod tas mazgāšanai un kịmiskajā tīî̀tavā, jālieto maskas un galvassegas, jāveic apavu un roku sanitārā apstrāde, jālieto cimdi. Kontroles metode - jāpalielina ražošanas automatizācija, jāuzstāda speciāla apmeklētāju caurlaides sistēma, jāsamazina darbinieku kontakts ar pārtikas izejvielām.

\subsection{MALTĀS ZIVJU PRODUKCIJAS RAŽOŠANAS EKONOMISKIE REZULTĀTI}

Izstrādāto produktu vienības izmaksu kalkulācijas ir robežās no 1055 EUR/t zivju pelmen,iem lĩdz 1521 EUR/t zivju pĩrāgiem; peḷnas normas sasniedz līdz 46\% (zivju pirāaiem) (9.-15. tabula).
9. tabula. Vienības izmaksas un pelnas norma zivju makaroniem Vienïba: EUR/t

\begin{tabular}{|c|c|c|c|}
\hline 1 & Pozīcija & Summa & $\%$ \\
\hline 2 & Pārdošanas cena & 2086,00 & $\mathrm{x}$ \\
\hline 3 & Ražošanas izmaksas & & $x$ \\
\hline 4 & Zivju masa & 95,43 & $7 \%$ \\
\hline 5 & Kviešu milti & 255,50 & $18 \%$ \\
\hline 6 & Olas & 73,00 & $5 \%$ \\
\hline 7 & Sāls & 0,56 & $0 \%$ \\
\hline 8 & Garšvielu maisijums & 182,50 & $13 \%$ \\
\hline 9 & P5 & 0,00 & $0 \%$ \\
\hline 10 & Elektroenerǵijas izmaksas & 28,93 & $2 \%$ \\
\hline 11 & Ražošanas personāla izmaksas & 117,41 & $8 \%$ \\
\hline 12 & lekārtu remonts un uzturēšana & 17,02 & $1 \%$ \\
\hline 13 & Siltumenerǵijas izmaksas & 17,47 & $1 \%$ \\
\hline 14 & Citas ražošanas izmaksas & 28,36 & $2 \%$ \\
\hline 15 & Ražošanas izmaksas kopā & 816,18 & $57 \%$ \\
\hline 16 & Administrācijas un pārdošanas izmaksas & & $x$ \\
\hline 17 & Administrācijas personāla izmaksas & 34,03 & $2 \%$ \\
\hline 18 & Grāmatvedỉbas un personälvadïbas ārpakalpojumi & 10,21 & $1 \%$ \\
\hline 19 & Citi administrācijas izdevumi & 22,69 & $2 \%$ \\
\hline 20 & Zivju makaroni, iepakojums & 100,00 & $7 \%$ \\
\hline 21 & Citi pārdošanas izdevumi & 11,34 & $1 \%$ \\
\hline 22 & Administrācijas un pārdošanas izm. kopā & 178,27 & $12 \%$ \\
\hline 23 & Nolietojums & 435,22 & $30 \%$ \\
\hline 24 & Procentu maksājumi & 0,00 & $0 \%$ \\
\hline 25 & Vidējās izmaksas kopā pirms nod. & 1429,67 & $100 \%$ \\
\hline 26 & Peḷna pirms ārkārtas pozīcijām un nodoḳliem & 656,33 & $31 \%$ \\
\hline
\end{tabular}

Piezīme: aprēkinā izmantoti 3. projekta gada dati; administrācijas un kopējās ražošanas izmaksas sadalîtas proporcionāli produkta îpatsvarám ieṇēmumos 


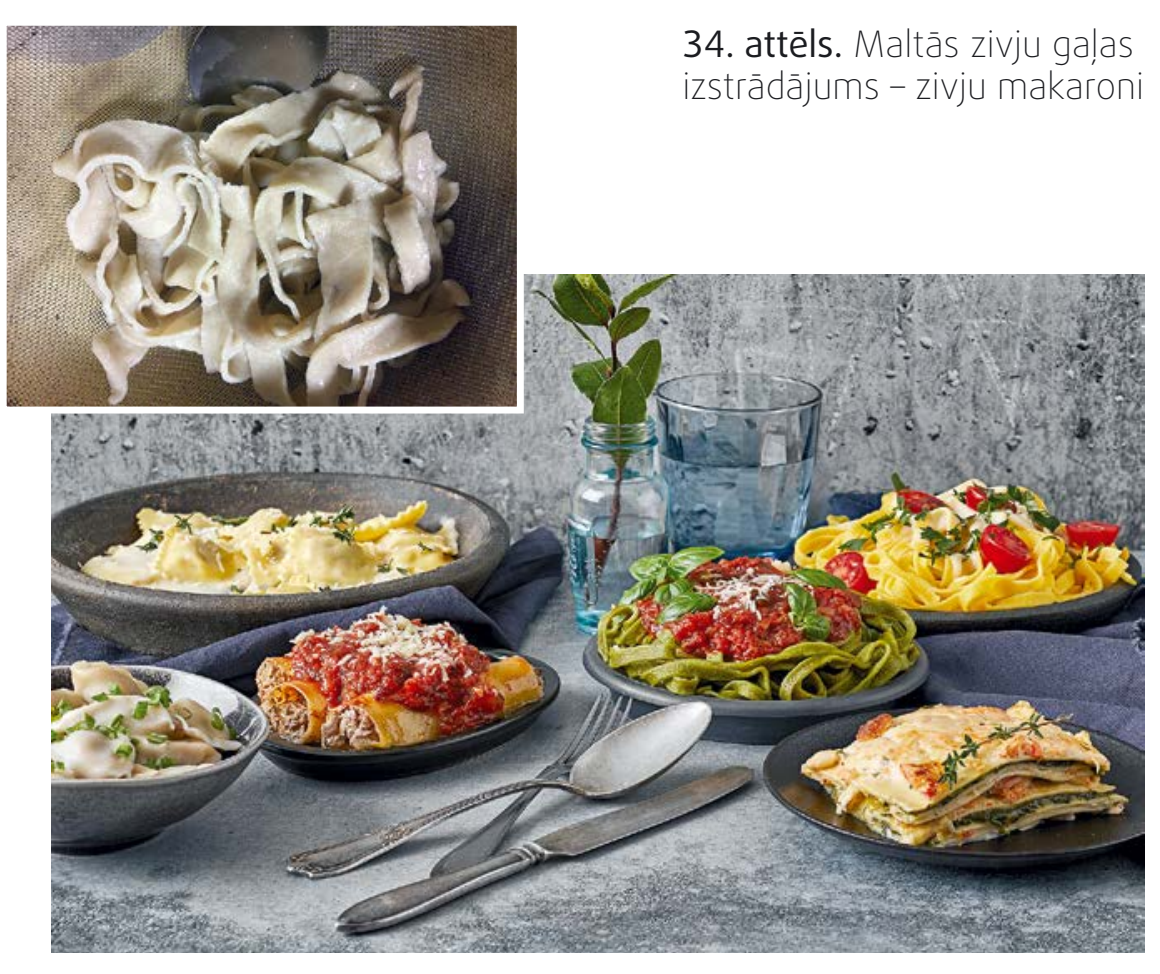

10. tabula. Vienïbas izmaksas un peln,as norma zivju pelmen,iem Vienība: EUR/t

\begin{tabular}{|c|l|c|c||}
\hline \hline 1 & Pozicija & Summa & $\%$ \\
\hline 2 & Pārdošanas cena & 1393,00 & $\mathbf{X}$ \\
\hline 3 & Ražošanas izmaksas & & $\mathbf{X}$ \\
\hline 4 & Zivju masa & 210,96 & $20 \%$ \\
\hline 5 & Kviešu milti & 170,00 & $16 \%$ \\
\hline 6 & Olas & 48,00 & $5 \%$ \\
\hline 7 & Sāls & 0,56 & $0 \%$ \\
\hline 8 & Sīpoli & 14,40 & $1 \%$ \\
\hline 9 & Garšvielu maisijums & 24,00 & $2 \%$ \\
\hline 10 & Augu ellla & 4,80 & $0 \%$ \\
\hline 11 & PE7 & 0,00 & $0 \%$ \\
\hline 12 & Elektroenerǵijas izmaksas & 19,32 & $2 \%$ \\
\hline
\end{tabular}

\begin{tabular}{|c|c|c|c|}
\hline 13 & Ražošanas personāla izmaksas & 78,40 & $7 \%$ \\
\hline 14 & lekārtu remonts un uzturēšana & 11,36 & $1 \%$ \\
\hline 15 & Siltumenerǵijas izmaksas & 11,67 & $1 \%$ \\
\hline 16 & Citas ražošanas izmaksas & 18,94 & $2 \%$ \\
\hline 17 & Ražošanas izmaksas kopā & 612,41 & $58 \%$ \\
\hline 18 & Administrācijas un pārdošanas izmaksas & & $x$ \\
\hline 19 & Administrācijas personāla izmaksas & 22,73 & $2 \%$ \\
\hline 20 & Grämatvedïbas un personälvadïbas ãrpakalpojumi & 6,82 & $1 \%$ \\
\hline 21 & Citi administrācijas izdevumi & 15,15 & $1 \%$ \\
\hline 22 & Zivju pelmeni, iepakojums & 100,00 & $9 \%$ \\
\hline 23 & Citi pārdošanas izdevumi & 7,58 & $1 \%$ \\
\hline 24 & Administrācijas un pārdošanas izm. kopā & 152,28 & $14 \%$ \\
\hline 25 & Nolietojums & 290,64 & $28 \%$ \\
\hline 26 & Procentu maksājumi & 0,00 & $0 \%$ \\
\hline 27 & Vidējās izmaksas kopā pirms nod. & 1055,33 & $100 \%$ \\
\hline 28 & Peḷna pirms ārkārtas pozīcijām un nodokḷiem & 337,67 & $24 \%$ \\
\hline
\end{tabular}

Piezīme: aprēkinā izmantoti 3 . projekta gada dati; administrācijas un kopējās ražošanas izmaksas sadalitas proporcionāli produkta ĩpatsvaram ieṇēmumos

35. attēls. Maltās zivju galas izstrādājums - zivju pelmen,i

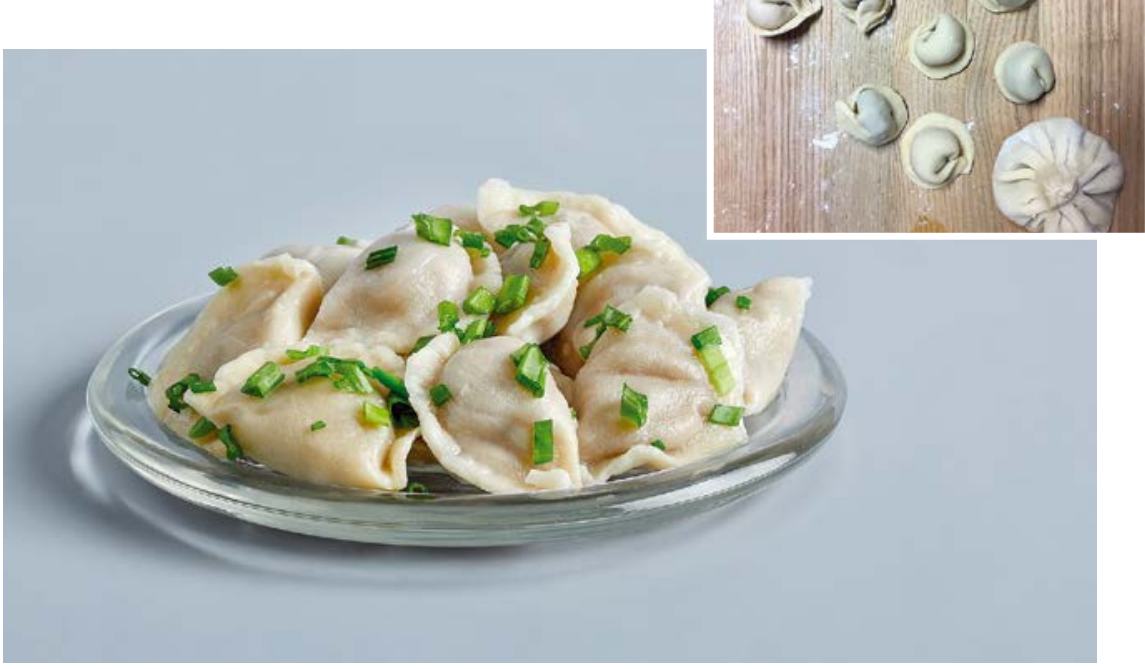


11. tabula. Vienības izmaksas un pelnas norma zivju desām Vienība: EUR/t

\begin{tabular}{|c|c|c|c|}
\hline 1 & Pozīcija & Summa & $\%$ \\
\hline 2 & Pārdošanas cena & 2030,00 & $\mathrm{x}$ \\
\hline 3 & Ražošanas izmaksas & & $x$ \\
\hline 4 & Zivju masa & 147,67 & $10 \%$ \\
\hline 5 & Sipoli & 21,90 & $2 \%$ \\
\hline 6 & Sojas izolāts & 219,00 & $15 \%$ \\
\hline 7 & Garšvielu maisijjums & 220,00 & $15 \%$ \\
\hline 8 & Margarīns & 36,75 & $3 \%$ \\
\hline 9 & D5 & 0,00 & $0 \%$ \\
\hline 10 & Elektroenerǵijas izmaksas & 28,16 & $2 \%$ \\
\hline 11 & Ražošanas personāla izmaksas & 114,26 & $8 \%$ \\
\hline 12 & lekārtu remonts un uzturēšana & 16,56 & $1 \%$ \\
\hline 13 & Siltumenerǵijas izmaksas & 17,00 & $1 \%$ \\
\hline 14 & Citas ražošanas izmaksas & 27,60 & $2 \%$ \\
\hline 15 & Ražošanas izmaksas kopā & 848,89 & $59 \%$ \\
\hline 16 & Administrācijas un pārdošanas izmaksas & & $x$ \\
\hline 17 & Administrācijas personāla izmaksas & 33,12 & $2 \%$ \\
\hline 18 & Grāmatvedibas un personālvadïbas ārpakalpojumi & 9,94 & $1 \%$ \\
\hline 19 & Citi administrācijas izdevumi & 22,08 & $2 \%$ \\
\hline 20 & Zivju desas, iepakojums & 100,00 & $7 \%$ \\
\hline 21 & Citi pārdošanas izdevumi & 11,04 & $1 \%$ \\
\hline 22 & Administrācijas un pārdošanas izm. kopā & 176,18 & $12 \%$ \\
\hline 23 & Nolietojums & 423,54 & $29 \%$ \\
\hline 24 & Procentu maksājumi & 0,00 & $0 \%$ \\
\hline 25 & Vidējās izmaksas kopā pirms nod. & 1448,61 & $100 \%$ \\
\hline 26 & Peḷna pirms ārkārtas pozīcijām un nodokḷiem & 581,39 & $29 \%$ \\
\hline
\end{tabular}

Piezīme: aprēkinā izmantoti 3. projekta gada dati; administrācijas un kopējās ražošanas izmaksas sadalîtas proporcionăli produkta îpatsvaram ienēmumos
36. attēls. Maltās zivju galas izstrādājums - zivju desas

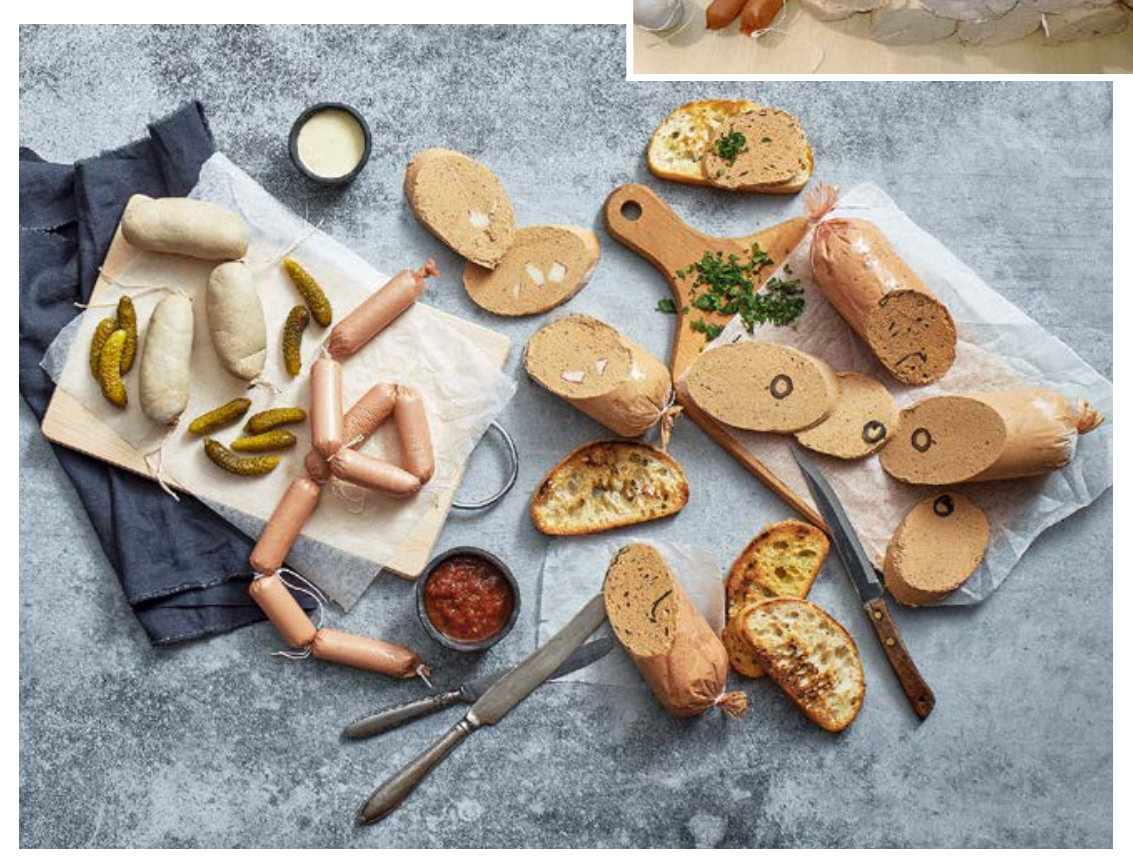

12. tabula. Vienības izmaksas un pelnas norma zivju pirkstiniem panējumā

Vienïba: EUR/t

\begin{tabular}{|c|l|c|c||}
\hline \hline 1 & Pozīija & Summa & $\%$ \\
\hline 2 & Pārdošanas cena & 1302,00 & $\mathbf{x}$ \\
\hline 3 & Ražošanas izmaksas & & $\mathbf{X}$ \\
\hline 4 & Zivju masa & 203,42 & $17 \%$ \\
\hline 5 & Sīpoli & 36,30 & $3 \%$ \\
\hline 6 & Sāls & 0,64 & $0 \%$ \\
\hline
\end{tabular}




\begin{tabular}{|c|c|c|c|}
\hline 7 & Margarīns & 50,50 & $4 \%$ \\
\hline 8 & Garšvielu maisijums Fishburger & 162,00 & $13 \%$ \\
\hline 9 & Sojas teksturāts & 182,10 & $15 \%$ \\
\hline 10 & Sausiṇu panējums & 20,25 & $2 \%$ \\
\hline 11 & Olas & 20,00 & $2 \%$ \\
\hline 12 & Z8 & 0,00 & $0 \%$ \\
\hline 13 & Elektroenerǵijas izmaksas & 18,05 & $1 \%$ \\
\hline 14 & Ražošanas personāla izmaksas & 73,28 & $6 \%$ \\
\hline 15 & lekārtu remonts un uzturēšana & 10,62 & $1 \%$ \\
\hline 16 & Siltumenerǵijas izmaksas & 10,90 & $1 \%$ \\
\hline 17 & Citas ražošanas izmaksas & 17,70 & $1 \%$ \\
\hline 18 & Ražošanas izmaksas kopā & 805,76 & $66 \%$ \\
\hline 19 & Administrācijas un pārdošanas izmaksas & & $x$ \\
\hline 20 & Administrācijas personāla izmaksas & 21,24 & $2 \%$ \\
\hline 21 & Grāmatvedïbas un personālvadỉbas ārpakalpojumi & 6,37 & $1 \%$ \\
\hline 22 & Citi administrācijas izdevumi & 14,16 & $1 \%$ \\
\hline 23 & Zivju pirkstini panējumā, iepakojums & 100,00 & $8 \%$ \\
\hline 24 & Citi pārdošanas izdevumi & 7,08 & $1 \%$ \\
\hline 25 & Administrācijas un pārdošanas izm. kopā & 148,85 & $12 \%$ \\
\hline 26 & Nolietojums & 271,65 & $22 \%$ \\
\hline 27 & Procentu maksājumi & 0,00 & $0 \%$ \\
\hline 28 & Vidējās izmaksas kopā pirms nod. & 1226,26 & $100 \%$ \\
\hline 29 & Peḷna pirms ārkārtas pozīijām un nodokḷiem & 75,75 & $29 \%$ \\
\hline
\end{tabular}
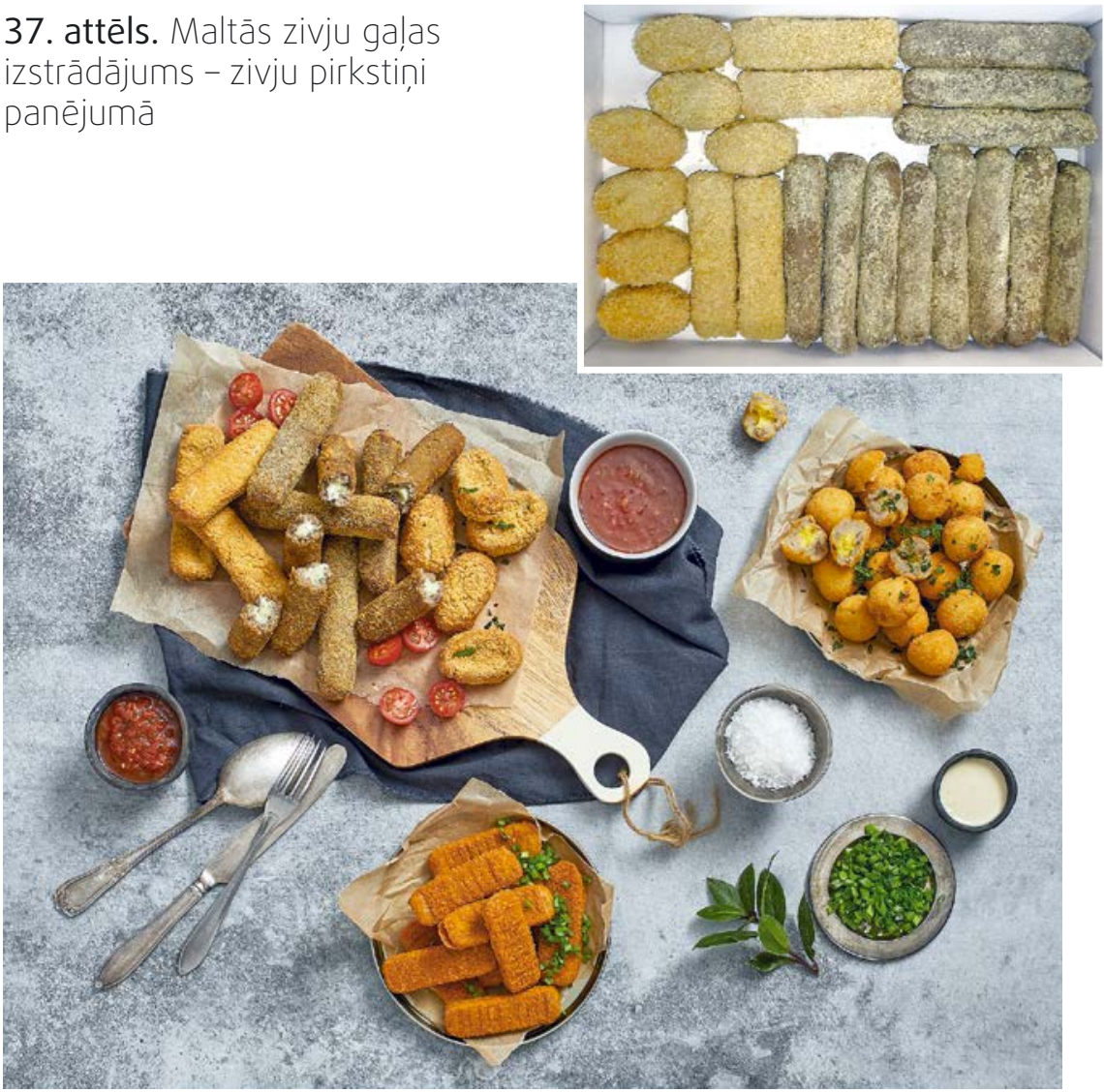

13. tabula. Vienības izmaksas un peḷnas norma zivju pīrāgiem

\begin{tabular}{|c|l|c|c||}
\hline 1 & Pozīcija & Summa & $\%$ \\
\hline 2 & Pārdošanas cena & $\mathbf{2 8 0 0 , 0 0}$ & $\mathbf{X}$ \\
\hline 3 & Ražošanas izmaksas & & $\mathbf{X}$ \\
\hline 4 & Zivju masa & 177,30 & $12 \%$ \\
\hline 5 & Kviešu milti & 125,50 & $8 \%$ \\
\hline 6 & Cukurs & 8,00 & $1 \%$ \\
\hline 7 & Olas & 41,00 & $3 \%$ \\
\hline
\end{tabular}

Piezīme: aprēkinā izmantoti 3. projekta gada dati; administrăcijas un kopējās ražošanas izmaksas sadalítas proporcionăli produkta îpatsvarám ieṇémumos 


\begin{tabular}{|c|c|c|c|}
\hline 8 & Sāls & 0,32 & $0 \%$ \\
\hline 9 & Presētais raugs & 24,00 & $2 \%$ \\
\hline 10 & Margarīns & 4,00 & $0 \%$ \\
\hline 11 & Dārzeṇi & 31,25 & $2 \%$ \\
\hline 12 & Sipoli & 12,30 & $1 \%$ \\
\hline 13 & Augu ella & 8,00 & $1 \%$ \\
\hline 14 & Garšvielu maisijums & 20,00 & $1 \%$ \\
\hline 15 & PR11 & 0,00 & $0 \%$ \\
\hline 16 & Elektroenerǵijas izmaksas & 38,83 & $3 \%$ \\
\hline 17 & Ražošanas personāla izmaksas & 157,59 & $10 \%$ \\
\hline 18 & lekārtu remonts un uzturēšana & 22,84 & $2 \%$ \\
\hline 19 & Siltumenerǵijas izmaksas & 23,45 & $2 \%$ \\
\hline 20 & Citas ražošanas izmaksas & 38,07 & $3 \%$ \\
\hline 21 & Ražošanas izmaksas kopā & 732,45 & $48 \%$ \\
\hline 22 & Administrācijas un pārdošanas izmaksas & & $x$ \\
\hline 23 & Administrācijas personāla izmaksas & 45,68 & $3 \%$ \\
\hline 24 & Grāmatvedïbas un personālvadïbas ārpakalpojumi & 13,70 & $1 \%$ \\
\hline 25 & Citi administrācijas izdevumi & 30,45 & $2 \%$ \\
\hline 26 & Zivju pīrāgi, iepakojums & 100,00 & $7 \%$ \\
\hline 27 & Citi pārdošanas izdevumi & 15,23 & $1 \%$ \\
\hline 28 & Administrācijas un pārdošanas izm. kopā & 205,06 & $13 \%$ \\
\hline 29 & Nolietojums & 584,19 & $38 \%$ \\
\hline 30 & Procentu maksājumi & 0,00 & $0 \%$ \\
\hline 31 & Vidējās izmaksas kopā pirms nod. & 1521,70 & $100 \%$ \\
\hline 32 & Peḷna pirms ārkārtas pozīcijām un nodokḷiem & 1278,30 & $46 \%$ \\
\hline
\end{tabular}

38. attēls. Maltās zivju gạlas izstrādājums - zivju pĩrāgl

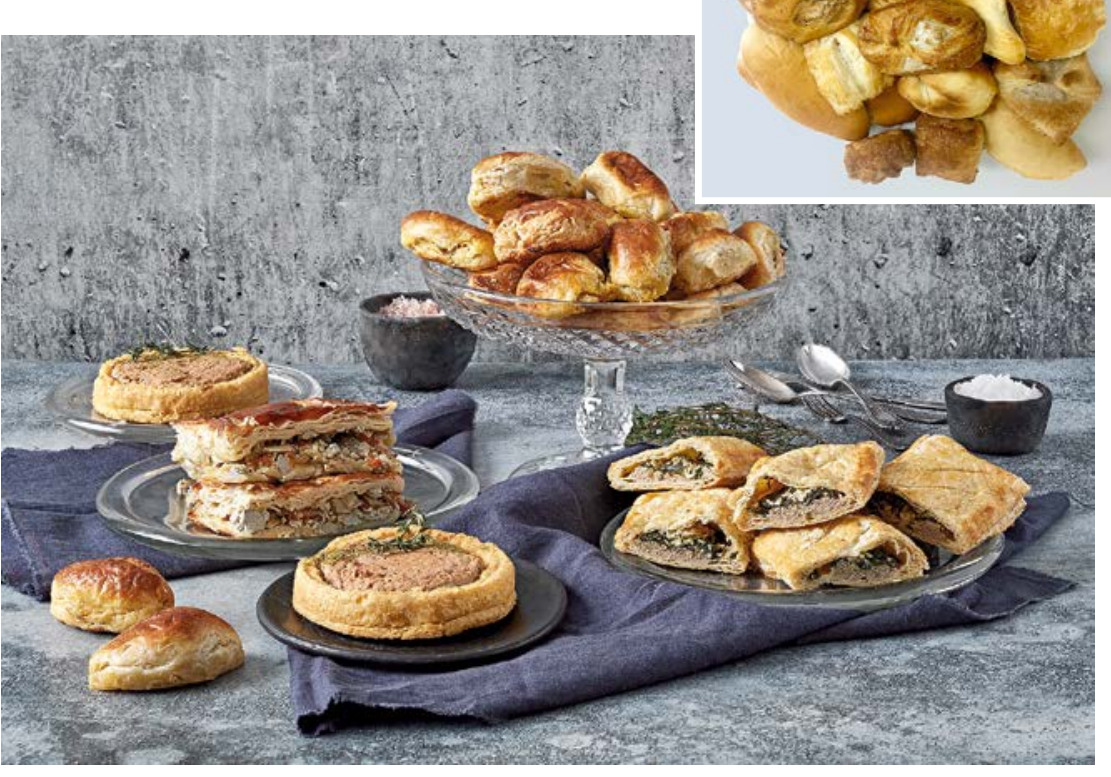

14. tabula. Vienības izmaksas un peln,as norma zivju terīnēm Vieniba: EUR/t

\begin{tabular}{|c|l|c|c||}
\hline \hline 1 & Pozicija & Summa & $\%$ \\
\hline 2 & Pārdošanas cena & 1813,00 & $\mathbf{X}$ \\
\hline 3 & Ražošanas izmaksas & & $\mathbf{X}$ \\
\hline 4 & Zivju masa & 397,81 & $29 \%$ \\
\hline 5 & Sīpoli & 8,91 & $1 \%$ \\
\hline 6 & Olas & 148,50 & $11 \%$ \\
\hline 7 & Augu ella & 19,80 & $1 \%$ \\
\hline 8 & Garšvielu maisijjums & 49,50 & $4 \%$ \\
\hline 9 & PT5 & 0,00 & $0 \%$ \\
\hline 10 & Elektroenerǵijas izmaksas & 25,14 & $2 \%$ \\
\hline 11 & Ražošanas personāla izmaksas & 102,04 & $8 \%$ \\
\hline 12 & lekārtu remonts un uzturēšana & 14,79 & $1 \%$ \\
\hline 13 & Siltumenerǵijas izmaksas & 15,18 & $1 \%$ \\
\hline
\end{tabular}




\begin{tabular}{|c|c|c|c|}
\hline 14 & Citas ražošanas izmaksas & 24,65 & $2 \%$ \\
\hline 15 & Ražošanas izmaksas kopā & 806,32 & $60 \%$ \\
\hline 16 & Administrācijas un pārdošanas izmaksas & & $x$ \\
\hline 17 & Administrācijas personāla izmaksas & 29,58 & $2 \%$ \\
\hline 18 & Grāmatvedības un personālvadības ãrpakalpojumi & 8,87 & $1 \%$ \\
\hline 19 & Citi administrācijas izdevumi & 19,72 & $1 \%$ \\
\hline 20 & Zivju terīnes ar olu, iepakojums & 100,00 & $7 \%$ \\
\hline 21 & Citi pārdošanas izdevumi & 9,86 & $1 \%$ \\
\hline 22 & Administrācijas un pārdošanas izm. kopā & 168,03 & $12 \%$ \\
\hline 23 & Nolietojums & 378,26 & $28 \%$ \\
\hline 24 & Procentu maksājumi & 0,00 & $0 \%$ \\
\hline 25 & Vidējās izmaksas kopā pirms nod. & 1352,61 & $100 \%$ \\
\hline 26 & Peḷna pirms ārkārtas pozīiijām un nodokḷiem & 460,39 & $25 \%$ \\
\hline
\end{tabular}

Piezīme: aprēkinā izmantoti 3. projekta gada dati; administrācijas un kopējās ražošanas izmaksas sadalítas proporcionāli produkta ĩpatsvaram ienēemumos

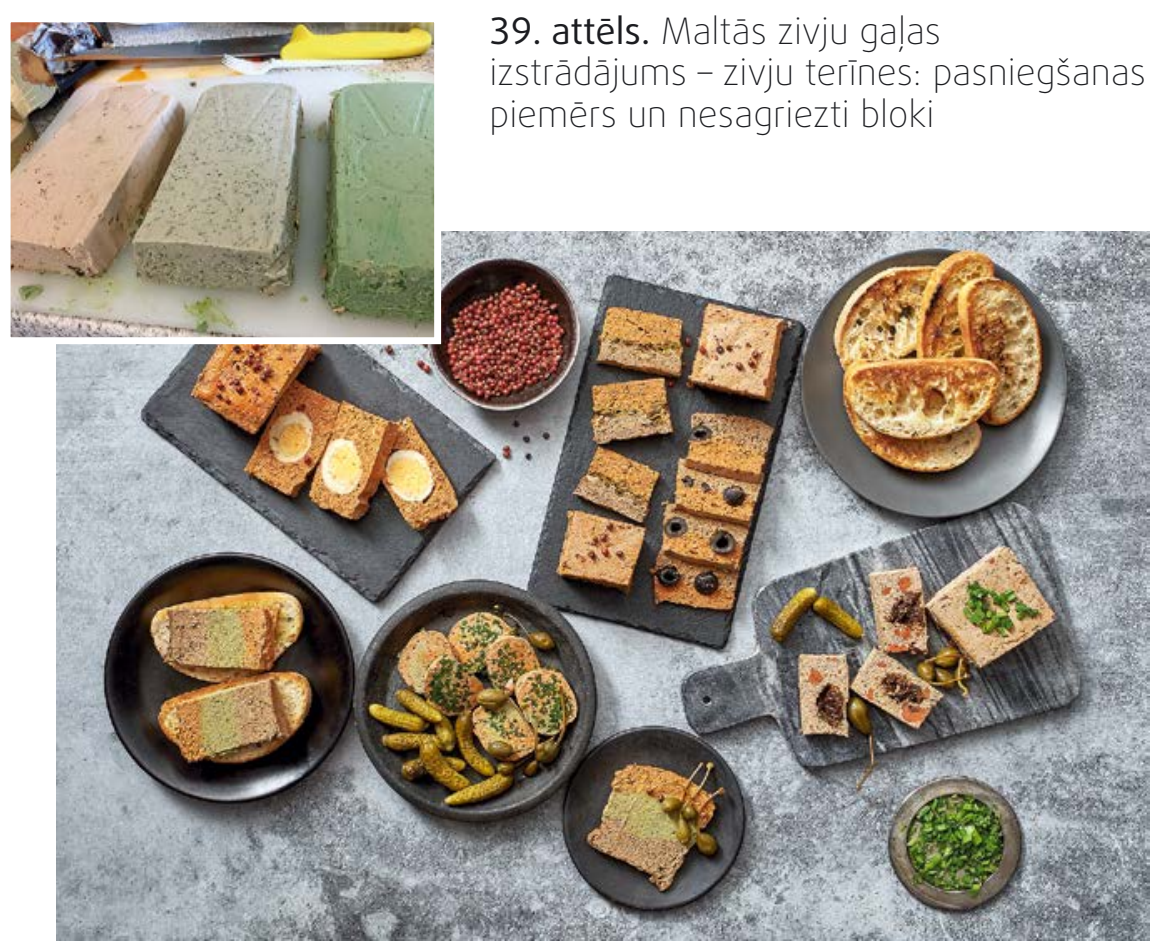

15. tabula. Vienības izmaksas un pelnas norma zivju kotletēm želejā Vieniba: EUR/t

\begin{tabular}{|c|c|c|c|}
\hline 1 & Pozīcija & Summa & $\%$ \\
\hline 2 & Pārdošanas cena & 2114,00 & $x$ \\
\hline 3 & Ražošanas izmaksas & & $x$ \\
\hline 4 & Zivju masa & 210,96 & $18 \%$ \\
\hline 5 & Sīpoli & 18,60 & $2 \%$ \\
\hline 6 & Dārzeṇi & 15,50 & $1 \%$ \\
\hline 7 & Burkāni & 1,00 & $0 \%$ \\
\hline 8 & Pētersīlu saknes & 16,00 & $1 \%$ \\
\hline 9 & Augu ella & 8,00 & $1 \%$ \\
\hline 10 & Pārtikas želatīns & 80,00 & $7 \%$ \\
\hline 11 & F7 & 0,00 & $0 \%$ \\
\hline 12 & Elektroenerǵijas izmaksas & 29,31 & $2 \%$ \\
\hline 13 & Ražošanas personāla izmaksas & 118,98 & $10 \%$ \\
\hline 14 & lekārtu remonts un uzturēšana & 17,24 & $1 \%$ \\
\hline 15 & Siltumenerǵijas izmaksas & 17,70 & $1 \%$ \\
\hline 16 & Citas ražošanas izmaksas & 28,74 & $2 \%$ \\
\hline 17 & Ražošanas izmaksas kopā & 562,03 & $48 \%$ \\
\hline 18 & Administrācijas un pārdošanas izmaksas & & $x$ \\
\hline 19 & Administrācijas personāla izmaksas & 34,49 & $3 \%$ \\
\hline 20 & Grāmatvedỉbas un personālvadỉbas ārpakalpojumi & 10,35 & $1 \%$ \\
\hline 21 & Citi administrācijas izdevumi & 22,99 & $2 \%$ \\
\hline 22 & Zivju kotletēm želejā & 100,00 & $8 \%$ \\
\hline 23 & Citi pārdošanas izdevumi & 11,50 & $1 \%$ \\
\hline 24 & Administrācijas un pārdošanas izm. kopā & 179,33 & $15 \%$ \\
\hline 25 & Nolietojums & 441,07 & $37 \%$ \\
\hline 26 & Procentu maksājumi & 0,00 & $0 \%$ \\
\hline 27 & Vidējās izmaksas kopā pirms nod. & 1182,43 & $100 \%$ \\
\hline 28 & Peḷna pirms ārkārtas pozīcijām un nodokḷiem & 931,57 & $44 \%$ \\
\hline
\end{tabular}

Piezīme: aprēkinā izmantoti 3. projekta gada dati; administrācijas un kopējās ražošanas izmaksas sadalîtas proporcionāli produkta îpatsvarám ienēmumos 


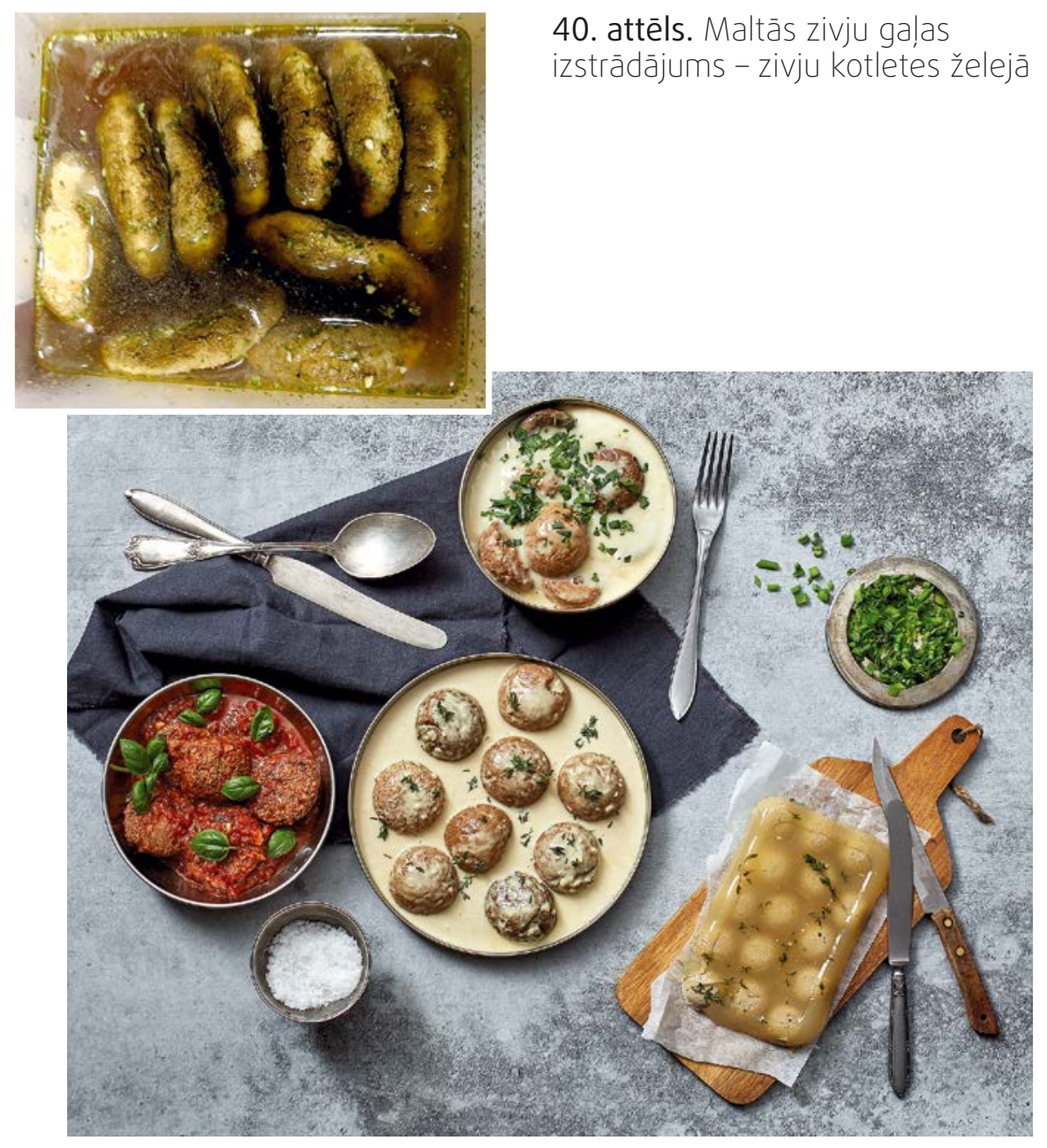

Lai piesaistîtu investoru, kurš būs spējīgs realizēt ražotnes izveidi projektā izstrādāto tehnoloǵiju un produktu ieviešanai ražošanā, vissvarīgākais ir indikatīvi demonstrēt šāda projekta investīiju efektivitātes rādītājus. Investīciju projektos jau agrā fāzē tiek praktizēta finanšu modelu sagatavošana, kas kalpo kā instrumenti ekonomiski pamatotu lēmumu pien,emšanā par projekta uzsākšanu principā un lēmumu pien,emšanā projektēšanas un ieviešanas gaitā. Šāda pieeja sekmē uz rezultātu orientētu lēmumu pien,emšanu, kurā kā kritēiiji tiek izmantoti finanšu un investīciju efektivitātes rādìtāji.

Izstrādātais izvērstais zivju restrukturētās kombinētās masas produktu ražošanas finanšu modelis Excel programmā izskata divus variantus. Bāzes variants paredz 410 t Baltijas brētliṇu apstrādi, realizējot produkciju Baltijas valstu tirgū. Optimistiskais variants paredz apstrādāt 25\% no Latvijas 2017. gadā eksportēto Baltijas brētlinu jeb 6928 t, kas būtu iespējams, sekmīgi realizējot produkciju lielos ārvalstu tirgos. Nosakot produktu realizācijas cenas, tika n,emts vērā līdzīgu produktu cenu līmenis, vairumtirgotāju un mazumtirgotāju uzcenojumi. Tomēr cenu veidošanu sarežǵíja apstāklis, ka atseviškiem produktiem, piemēram, zivju makaroniem nav analogu, tādē! tika izmantots tuvāko līdzīgāko produktu cenu līmenis tirgū. Sagatavojot finanšu modelus tika pien,emts, ka projekti tiek realizēti bez publiskā atbalsta. 
16. tabula. Galvenie finanšu un ekonomiskie rādītāji, bāzes variants

\begin{tabular}{|c|c|c|c|c|c|c|c|c|c|c|}
\hline Gads & 2019 & 2020 & 2021 & 2022 & 2023 & 2024 & 2025 & 2026 & 2027 & 2028 \\
\hline Neto apgrozījums & 0 & 2358720 & 4717440 & 4717440 & 4717440 & 4717440 & 4717440 & 4717440 & 4717440 & 4717440 \\
\hline EBITDA & -106344 & 1591428 & 2905872 & 2905872 & 2905872 & 2905872 & 2905872 & 2905872 & 2905872 & 2905872 \\
\hline EBITDA marža, \% & 0 & 67 & 62 & 62 & 62 & 62 & 62 & 62 & 62 & 62 \\
\hline Tìrā peḷna vai zaudējumi & -106344 & 1169172 & 2061360 & 2061360 & 2061360 & 2061360 & 2393582 & 2725764 & 2725764 & 2725764 \\
\hline Komerciālā rentabilitāte, \% & 0 & 50 & 44 & 44 & 44 & 44 & 51 & 58 & 58 & 58 \\
\hline ROE (finanšu rentabilitāte), \% & -4 & 16 & 22 & 18 & 15 & 13 & 13 & 13 & 12 & 10 \\
\hline ROA (ekonomiskā rentabilitāte), \% & -4 & 15 & 21 & 18 & 15 & 13 & 13 & 13 & 12 & 10 \\
\hline Bruto pievienotā vērtība & -37800 & 1856046 & 3356772 & 3356772 & 3356772 & 3356772 & 3356772 & 3356772 & 3356772 & 3356772 \\
\hline Nodarbināto skaits, pilna laika ekvivalentā & 2 & 8 & 22 & 22 & 22 & 22 & 22 & 22 & 22 & 22 \\
\hline Brētliṇu patērin,š, t & 0 & 204 & 408 & 408 & 408 & 408 & 408 & 408 & 408 & 408 \\
\hline Tīrā tagadnes vērtība & & 8636049 & & & & & & & & \\
\hline IRR (iekšejāss atdeves koeficients) & & 0,35 & & & & & & & & \\
\hline Kopējās investīciju izmaksas pamatlīdzeklos & & 6227000 & & & & & & & & \\
\hline leguldījumi apgrozāmajos līdzeklıs & & 213000 & & & & & & & & \\
\hline \multicolumn{4}{|c|}{ Finansējuma avoti } & & & & & & & \\
\hline Uzṇēmuma dalı apmaksa & & 6440000 & & & & & & & & \\
\hline Aizṇēmumi & & 0 & & & & & & & & \\
\hline
\end{tabular}


Bāzes variantā (16. tab.). Finanšu modelis ir veidots ar 10 gadu plānošanas horizontu. Tas ietver naudas plūsmu pa gadiem un pa mēnešiem, pel̦,nas vai zaudējumu aprêkinu, bilanci, tīrās tagadnes vērtības un atmaksāšanās perioda aprēkinu, katra saražotā produkcijas veida vienības izmaksu un pe!̣,nas normas aprēkinu, ieviešanas grafiku, galveno finanšu rādītāju kopsavilkumu investoram, kā arī izvērstu projekta pien,ēmumu ievades lauku kopumu.

Šis variants paredz restrukturētas kombinētās zivju masas ražošanas iekārtas un divu produkcijas ražošanas līniju uzstādī̌anu. Bāzes variantā (16. tab.) plānotais investīciju apjoms pamatlīdzekḷos veido 6,23 milj. EUR, tostarp 3,32 milj. EUR iekārtu iegādei, 2,66 milj. EUR būvniecībai, savukārt 0,24 milj. EUR tehniskā, tehnoloǵiskā projekta sagatavošanai, autoruzraudzībai un būvuzraudzībai. Bāzes variantā projekta vienkāršais un diskontētais atmaksāšanās laiks ir 5 gadi $(r=0,05)$. lekšējās atdeves koeficienta līmenis ir samērā augsts 0,35. Restrukturētas kombinētās zivju masas izgatavošanas tiešās ražošanas izmaksas (brētlin,as, pārtikas piedevu maisījums, manna un ciete) veido aptuveni 0,5 EUR par kg. Savukārt balto zivju maltā gala, kuru šobrīd izmanto konkurējošos produktos, maksā 1,3-1,6 EUR/kg. Būtisks pašizmaksas samazinājums rada iespēju nodrošināt augstu komerciālo rentabilitāti, kas ir pietiekama, lai radītu interesi potenciālajos investoros un projekts tiktu realizēts. Jāsaprot, ka lielāko risku investoram rada tirgus faktors - tas, kādas būs faktiskās sekmes Baltijas valstu tirgos jauno produktu realizācijā. Lai nodrošinātu plānoto realizācijas apjomu, būs jāsasniedz aptuveni 5\% no Baltijas tirgus apjoma šāda veida produktiem. Piedāvājot kvalitatīvus jaunievedumus, tas ir izaicinošs, bet augsti profesionālai mārketinga komandai sasniedzams mērkis.
Optimistiskajā variantā (17. tab.) ir pienemts, ka restrukturētas kombinētās zivju masas produktos tiek izmantoti nedaudz vairāk kā 13\% 2017. gadā no Latvijas eksportēto brētlin,u. Optimistiskais variants paredz restrukturētas kombinētās zivju masas ražošanas iekārtas un septiṇu produkcijas ražošanas līniju uzstādī̌̌anu. Projekta realizācijai nepieciešami ievērojami kapitālieguldījumi. Strādājot vienā maiñā, projekta diskontētais atmaksāšanās periods būtu 8 gadi, kas, n,emot vērā projekta tirgus risku, padara to mazāk pievilcīgu augsta riska investoriem. Turpretī, strādājot divās mainās, gan vienkāršais, gan diskontētais atmaksāšanās periods ir tikai 5 gadi, tādẹl optimistiskajā variantā izmantots 2 maiṇu darba pien,ēmums. Šajā gadijumā saražotās produkcijas apjoms ievērojami pārsniedz Baltijas tirgus kapacitāti. Projekta investīciju efektivitāte ir loti augsta, tīrā tagadnes vērtība 10 gadu periodā pārsniedz 20 milj. EUR, IRR vērtība 0,34. Tajā pat laikā jāuzsver, ka ir augsta varbūtība, ka neizdosies realizēt šādu produkcijas apjomu. Tirgus risks samazināsies, ja projektu realizēs investors, kurš labi pārzina vienu vai vairākus nozīmīgus eksporta tirgus ar lielu iedzīvotāju skaitu. Lai samazinātu tirgus risku, ieteicams vispirms realizēt projektu tā bāzes variantā, jau pirmsākumos plānojot iespējas paplašināt ražotni. Faktiski, pārdotās produkcijas apjoms norādīs uz tirgus riska līmeni lielāka apjoma ražošanā un ražošanas jaudas kāpināšanas pamatotību.

Svarīgākais praktiskais rezultāts no ekonomiskā viedokla ir tas, ka projekta prognozētais investīciju efektivitātes līmenis ir pietiekami augsts, lai, apzinoties tirgus riskus, tomēr radītu investoru interesi un turpinātos tà realizàcija. 
17. tabula. Galvenie finanšu un ekonomiskie rāditāji, optimistiskais variant

\begin{tabular}{|c|c|c|c|c|c|c|c|c|c|c|}
\hline Gads & 2019 & 2020 & 2021 & 2022 & 2023 & 2024 & 2025 & 2026 & 2027 & 2028 \\
\hline Neto apgrozijums & 0 & 10859184 & 21718368 & 21718368 & 21718368 & 21718368 & 21718368 & 21718368 & 21718368 & 21718368 \\
\hline EBITDA & -316800 & 4283466 & 7124676 & 7099068 & 7099068 & 7099068 & 7099068 & 7099068 & 7099068 & 7099068 \\
\hline EBITDA marža, \% & 0 & 39 & 33 & 33 & 33 & 33 & 33 & 33 & 33 & 33 \\
\hline Tīrā peḷ,na vai zaudējumi & -316800 & 3181404 & 4920552 & 4894944 & 4894944 & 4894944 & 4894944 & 6717144 & 6717144 & 6717144 \\
\hline Komerciālā rentabilitāte, \% & 0 & 29 & 23 & 23 & 23 & 23 & 27 & 31 & 31 & 31 \\
\hline ROE (finanšu rentabilitāte), \% & -6 & 17 & 20 & 17 & 14 & 13 & 13 & 13 & 12 & 10 \\
\hline ROA (ekonomiskā rentabilitāte), \% & -6 & 16 & 20 & 17 & 14 & 12 & 13 & 13 & 11 & 10 \\
\hline Bruto pievienotā vērtība & -140400 & 5162106 & 8680356 & 8654748 & 8654748 & 8654748 & 8654748 & 8654748 & 8654748 & 8654748 \\
\hline Nodarbināto skaits, pilna laika ekvivalentā & 5 & 36 & 68 & 68 & 68 & 68 & 68 & 68 & 68 & 68 \\
\hline Brētliṇu patērin,š, t & 0 & 1868 & 3736 & 3736 & 3736 & 3736 & 3736 & 3736 & 3736 & 3736 \\
\hline Tīrā tagadnes vērtība & \multicolumn{3}{|c|}{20891761} & & & & & & & \\
\hline IRR (iekšejāss atdeves koeficients) & \multicolumn{3}{|c|}{0,34} & & & & & & & \\
\hline Kopējās investīciju izmaksas pamatlīdzeklos & \multicolumn{3}{|c|}{15271000} & & & & & & & \\
\hline leguldijumi apgrozāmajos līdzeklos & \multicolumn{3}{|c|}{1079000} & & & & & & & \\
\hline \multicolumn{4}{|c|}{ Finansējuma avoti } & & & & & & & \\
\hline Uzṇēmuma dalı apmaksa & \multicolumn{3}{|c|}{16350000} & & & & & & & \\
\hline Aiz,̣ēmumi & \multicolumn{3}{|c|}{0} & & & & & & & \\
\hline
\end{tabular}


18. tabula. Projekta variantu salìdzinājums

\begin{tabular}{|c|c|c|}
\hline Varianta nosaukums & $\begin{array}{l}\text { Baltijas tirgus } \\
\text { (bāzes variants) }\end{array}$ & $\begin{array}{l}\text { Optimistiskais } \\
\text { variants }\end{array}$ \\
\hline Investīciju izmaksas, milj. EUR* & 6,22 & 15,27 \\
\hline Pārstrādāto brētliṇu apjoms gadā** , t & 408 & 3736 \\
\hline $\begin{array}{c}\text { Izmantoto brētlin, }{ }^{* *} \text { īpatsvars } \\
\text { Latvijas 2017. gadá brētlin,u eksporta } \\
\text { apjomā, \% }\end{array}$ & 1,47 & 13,47 \\
\hline Produkcijas apjoms gadā**, t & 1920 & 16800 \\
\hline Neto apgrozijums gadā**, milj. EUR & 4,72 & 21,72 \\
\hline $\begin{array}{c}\text { Bruto pel,na vai zaudējumi gadā**, } \\
\text { milj. EUR }\end{array}$ & 2,06 & 7,45 \\
\hline 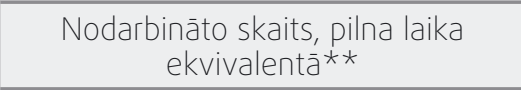 & 22 & 68 \\
\hline $\begin{array}{c}\text { Bruto pievienotā vērtība faktoriz- } \\
\text { maksās**, milj. EUR }\end{array}$ & 3,35 & 8,68 \\
\hline
\end{tabular}

Piezīmes: *- pieṇēmums, izmaksas noteiks realizācijas vietas, būvprojekta un tehnoloǵiskà projekta izvēlētie risinājumi, izmantoto resursu tirgus cenas; **- pirmajā pilnajā gadă pêc ražotnes izveides

\subsection{LATVIJAS ZIVJU RESURSI}

Saskañā ar Starptautiskās Jūras pētniecības padomes (ICES) datiem, galvenos jūras zivju resursus Latvijā veido tādas rūpnieciski nozīmìgas sugas kā brêtliṇas (Sprattus sprattus), ren,ǵes (Clupea harengus membras), mencas (Gadus morhua), laši (Salmo salar) un plekstes (Platichthys flesus). Mencu, lašu un plekšu nozveja ir vērā n,emami ierobežota vai aizliegta.

Latvijas ekonomiskā zona ir viena no bagātākajām Baltijas jūras komerciālo zivju apjoma ziṇā, bet Rīgas jūras līcim raksturīga produktivitāte līdz pat 12 kg/ha, un tā ir viena no ražīgākajām nozvejas vietām ziemelu puslodē. 2016. gadā Latvijas zvejas flote kopumā nozvejoja 56,6 tūkstošus tonnu zivju, kas ir par 5\% mazāk nekā 2015. gadā un par 3\% vairāk nekà 2014. gadā.
Salìdzinājumā ar 2015. gadu tika samazinātas pielaujamās nozvejas normas visām svarīgākajām zivju sugām - liča renǵém, brētliñām un mencām. 2016. gada kvota brētliṇām tika izmantota pilnībā, bet rengéēm par 98,3\%. 2017. gadā, salīdzinājumā ar 2016. gadu, kopējā nozvejas kvota palielinājās par 9,5\%. levērojamo pieaugumu pamatā noteica būtiska brētliṇu zvejas iespēju uzlabošanās.

Nozvejas apjoma ziṇā brētliṇas ir galvenās komerciālās zivis Baltijas jūrā. 2016. gadā tika nozvejoti 28 tūkstoši tonnu brētlinu, kas ir aptuveni 50\% no kopējā nozveja apjoma. 2016. gadā renǵu (Baltijas silku) nozveja bija 23,3 tūkstoši tonnu, kas ir 41\% no kopējās nozvejas apjoma.

19. tabula. Kvotas un faktiskā nozveja Baltijas jūrā, tonnās

\begin{tabular}{|c|c|c|c|}
\hline & Brētliṇas & Reṇǵes & Kора̄ \\
\hline \multicolumn{4}{|c|}{ 2016. gads } \\
\hline Kvota & 27990 & 23712 & 55738 \\
\hline Nozveja & 28101 & 28101 & 28101 \\
\hline \multicolumn{4}{|c|}{ 2017. gads } \\
\hline Kvota & 36107 & 22023 & 61021 \\
\hline
\end{tabular}

\subsubsection{Brētlina (sprattus sprattus)}

2016. gadā Latvijas zvejnieki nozvejoja 28,1 tūkst. t brētliṇu, kas ir par 2,4 tūkst. t mazāk nekā 2015. gadā. Rīgas līcī tika nozvejotas 1,6 tūkst. t brētliṇu. Pielaujamā nozveja uz 2016. gadu tika samazināta par 5,3\%. Latvijas brētliṇu kvota 2016. gadā bija 27990 t, kas tika pilnībā apgūta.

Visu valstu kopējāa brētliṇu nozveja 2016. gadā bija 246500 t un par 0,7 tūkst. t mazāka nekā 2015. gadā. Kopumā Eiropas Savienības dalïbvalstis brētliṇu nozvejas kvotu pārzvejojušas par 9,6 tūkst. tonnu. Visas valstis gandrīz pilnībā izmantoja savas kvotas, bet 
Lietuva, Zviedrija un Somija pārzvejoja savu kvotu, lai gan informācija par iespējamām kvotu apmainām nav pieejama. Arī Krievija nozvejoja daudz vairāk brētliṇu, nekā to paredzēja vienošanās ar ES.

Brētliṇu krājumi krasi palielinājās 90. gadu sākumā. Pieaugumu veicināja ražīgas paaudzes, zemā zvejas intensitāte un mencu kā plēsēju ietekmes uz brētliṇu krājumiem samazināšanās. Visaugstākā nārsta krājuma biomasa bija 1996. - 1997. gadā, bet pēc tam tā samazinājās, tomèr visu laiku atrodoties samērā augstā līmenī. Brètliṇu nārsta bara biomasa būtiski palielinājās 2010. gadā, kad krājumu papildināja ražĩgã 2008. gada paaudze, bet pēc tam tā pakāpeniski samazinājās. Brētlināan ir raksturīgs loti svārstīgs paaudžu ražīgums, un tas var būtiski ietekmēt krājumu dinamiku. Pēdējos gados loti ražīgas paaudzes bija 2003. un 2008. gadā, pēc kuru parādišanās krājumi būtiski palielinājās. Sākot ar 2009. gadu, paaudzes bija neražīgas vai vidēji ražĩgas, tāpēc krājumi lēnām samazinājās. Tikai 2014. gadà beidzot bija radusies loti ražīga paaudze, tāpēc krājumi sāka palielināties. Visumā var teikt, ka šajā gadsimtā, salīdzinot ar 90. gadiem, loti ražĩgas paaudzes vairs neparādās tik bieži. Domājams, ka, līdzīgi kā Rĩgas lǐča renggeèm, arī brētliṇu atražošanās procesam ir labvēlīgas siltas ziemas, bet ir arī citi nenoskaidroti apstākli, kas būtiski ietekmē brētliṇu paaudžu ražǐbu.

8.5.2. Renǵges (clupea harengus membras)

2016. gadā Latvijas kopējā renǵu nozveja šajā rajonā bija 7034 t, kas bija par 2770 t vairāk nekà 2015. gadā. Nozvejas kvota tika pilnībāa apgūta. Kā parasti, mazākās renǵu nozvejas bija vasaras mēnešos, bet vislielākās - 4. ceturksnī, kad ieguva vairāk nekā pusi no kopējām nozvejām. Nozvejas piekrastē bija tikai 45 t, kas ir par 28 t mazāk nekā iepriekšējā gadà.

2016. gadā renǵu nozvejās Baltijas jūrā visvairāk bija 4 un 5 gadus vecas rengges, kas ir 2011. - 2012. gada paaudze. Laika posmā pēc 2002. gada ražĩgas paaudzes sāka parādìties biežāk nekā 90-tajos gados. Pèdējos gados salīdzinoši l, toti ražīgas bija 2007., 2008. 2011. un 2012. gada paaudzes. Loti ražĩga bija 2014. gada paaudze, kas tika novērtēta kā daudzskaitlīgākā visā novērojumu periodà kopš 1974. gada. Jāatzīmē, ka 2014. gada paaudze bija ražĩga visā Baltijas jūrā, izṇemot Rīgas līci. Renǵ̣u vidējie bioloǵiskie rādîtāji visās vecuma grupās bija zemāki nekā iepriekšējā gadā.

Renǵu krājumi Baltijas jūras centrālajā dạā pakāpeniski samazinājās kopš 70. gadiem un gadsimtu mijā sasniedza zemāko līmeni 427 tūkst. tonnu. Pēc tam krājumi sāka pakāpeniski palielināties. Ša krājuma vienïbai pēdējos gados vairākkārt pārrēkịināja jauno zvejas mirstību, tāpēc arī pieḷujamās nozvejas tika krasi samazinātas vai, kā tas ir pēdējos gados, ievērojami palielinātas.

Uz 2017. gadu renǵu pielaujamā nozveja tika palielināta par 7,7\%. Latvijas renǵu kvota Baltijas jūras centrālajā dalā 2017. gadā bija 5299 t, kas ir par 378 t vairāk nekā iepriekšējāa gadā.

20. tabula. Nozvejas kvotas Baltijas jūrā un Rīgas līcī pa zivju sugām un valstīm 2017. g. tonnăs

\begin{tabular}{||c|c|c||}
\hline Valsts & $\begin{array}{c}\text { Brētlinas } \\
\text { Sprattus sprattus }\end{array}$ & $\begin{array}{c}\text { Renǵes } \\
\text { Clupea harengus } \\
\text { membras }\end{array}$ \\
\hline Dānija & 25745 & 8186 \\
\hline Igaunija & 29896 & 35823 \\
\hline Latvija & 36107 & 22023 \\
\hline Lietuva & 13061 & 5580 \\
\hline Polija & 76627 & 51313 \\
\hline Somija & 13477 & 157511 \\
\hline Vācija & 16310 & 16785 \\
\hline Zviedrija & 49770 & 94377 \\
\hline Kopā & 260993 & 391598 \\
\hline
\end{tabular}

Svaigu zivju, kas būtu derīgas pārtikas pārstrādē, sezona ilgst no septembra/oktobra līdz martam/aprïlim. No zivju pārstrādes viedokla brētlinas izmanto preservos ar ierobežotu uzglabāšanas termiṇu līdz 
6 mēnešiem, kā arī konservētās šprotēs, kuru tirgus ir pietiekami tradicionāls un ierobežots.

Renǵes arī izmanto šprotu ražošanā, turklāt tās veiksmīgi tiek realizētas karsti kūpinātā veidā.

21. tabula. Latvijas nozvejas kvotas Baltijas jūrā un Rīgas līcì pa zivju sugām 2008.-2017. g., tonnās

\begin{tabular}{|c|c|c||}
\hline Gads & $\begin{array}{c}\text { Brētlinas } \\
\text { Sprattus sprattus }\end{array}$ & $\begin{array}{c}\text { Renǵges } \\
\text { Clupea harengus } \\
\text { membras }\end{array}$ \\
\hline 2008 & 62877 & $23658^{\star}$ \\
\hline 2009 & 55332 & $22761^{\star}$ \\
\hline 2010 & 52565 & $23095^{\star}$ \\
\hline 2011 & 39949 & $22569^{\star}$ \\
\hline 2012 & 31160 & $18630^{\star}$ \\
\hline 2013 & 34583 & $18956^{\star}$ \\
\hline 2014 & 32080 & $22650^{\star}$ \\
\hline 2015 & 29548 & $25404^{*}$ \\
\hline 2016 & 27990 & 23712 \\
\hline 2017 & 36107 & 22023 \\
\hline \hline
\end{tabular}

* Renǵu kvota Rĩgas līcī

Nozvejotās zivis tiek izmantotas kā izejviela mājdzīvnieku barības ražošanā, kā arī pārstrādātas zivju miltos. Taču pēdējais pārstrādes veids ir ekonomiski mazāk izdevīgs, jo, salīdzinājumā ar pārtikas produkcijas ražošanu, tam ir ievērojami samazināta pievienotā vērtība. Piedāvātā tehnoloǵija nodrošina pieejamo zivju izejvielu pilnīgu pārstrādi.

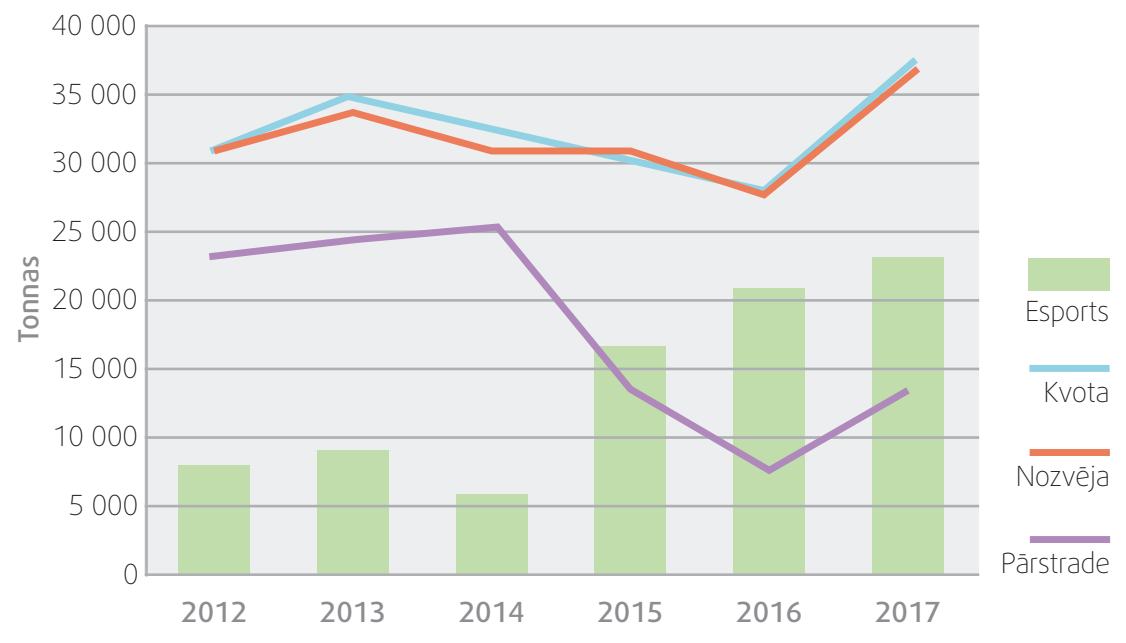

41. attēls. Brētliñas nozvejas un pārstrādes dinamika 2012.-2017. gados

\subsection{PILNĪGA IZEJVIELU PĀRSTRĀDE} KĀ ILGTSPËJIIGA UN EFEKTİVA VIETĖJO RESURSU IZMANTOŠANA

Latvijas stratēǵiskā bagātība ir tās Baltijas brētlin,u resursi, kurus esam ieinteresēti apstrādāt Latvijā, izgatavot realizācijai gatavus zivju maltās gallas produktus. Pilnīga izejvielu pārstrāde rerstrukturētos zivju produktos uzlabos Latvijas ārējās tirdzniecības bilanci, jo pieaugs kopējie ien,ēmumi no zivju produkcijas eksporta (22. tab.). Eksportējot neapstrādātas brētlinas un pienemot, ka to realizācijas cena ir 0,40 EUR/kg, kopējie eksporta ien,ēmumi būtu 11,09 milj. EUR. Praksē uzn,ēmumi nodrošina arī augstākus ien,ēmumus par produkcijas vienību, piemēram, individuāli sasaldējot brētlinas IQF iekārtās. Realizējot restrukturētas kombinētas zivju masas produktu ražošanas projektu, nedaudz samazinātos ienēmumi no brētlinu eksporta, savukārt būtu sagaidāms ievērojams pieaugums no eksportētās zvejas produktu apstrādes produkcijas ienēmumiem. Šì ražošana sniegs kvalitatīva rakstura papildu pienesumu Latvijā ražoto zvejas apstrādes produktu klāstam un jaunas iespējas apgūt ārvalstu tirgus, zināmā mērā kompensējot zaudējumus, kurus radīja šprotu ražošanas apjoma samazinājums kopš 2014. gada. 
22. tabula. Projekta ietekme uz Latvijas ārējās tirdzniecības bilanci

\begin{tabular}{||c|c|c|c||}
\hline \hline Varianta nosaukums & $\begin{array}{c}\text { Esošā } \\
\text { situăcija }\end{array}$ & $\begin{array}{c}\text { Bāzes } \\
\text { variants }\end{array}$ & $\begin{array}{c}\text { Optimistiskais } \\
\text { variants }\end{array}$ \\
\hline Brētliṇu eksports, t & 27735 & 27327 & 23999 \\
\hline $\begin{array}{c}\text { leñēmumi no brëtlinu eks- } \\
\text { porta, milj. EUR }\end{array}$ & 11,09 & 10,93 & 9,60 \\
\hline $\begin{array}{c}\text { lenēmumi no restrukturētas } \\
\text { kombinētas zivju masas } \\
\text { produktu eksporta, milj. } \\
\text { EUR* }\end{array}$ & 0 & 3,15 & 20,15 \\
\hline $\begin{array}{c}\text { Kopejjie ienēmumi no } \\
\text { eksporta, milj. EUR }\end{array}$ & $\begin{array}{c}\text { Brētlinu eks- } \\
\text { ports, t }\end{array}$ & 11,09 & 29,75 \\
\hline \hline
\end{tabular}

Piezīmes: *- bez produkciijas dalas, kura realizēta vietējā tirgū: pienemts, ka brētliṇu cena ir 0.2 tūkst. EUR/t un eksporta apjoms saglabājas 2017. g. līmenî Avots: Autoru aprēkini

Salīdzinājumam izskatīsim dažādu no brētlinām izgatavotu produktu tiešo pievienoto vērtību. Eksportējot 1 kg saldētu brētliṇu, sanemam 0,4 eiro centus. Ja no 1 kg brētlin,u tiek izgatavoti paši vienkāršākie konservi - brētlinas tomātu mērcē, šo kilogramu iespējams eksportēt jau par 1,4 eiro. Ja šis kilograms tiek pārdots šprotu formā, cena uzkāpj lìdz 2,75 eiro. Bet kas būs, ja no 1 kilograma brētlin,u tiks izgatavoti restrukturēti produkti?

Saskaṇāa ar izstrādātajām receptēm no 1 kg brētliṇu var izgatavot šādu daudzumu dažādu produktu ar sekojošu tiešo pašizmaksu (tikai izejvielas, atškirī̄bā no pilnas izmaksu kalkulācijas iepriekš aprakstītajā finanšu modelī)

23. tabula. No 1 kg brētlinu iegūstamā produkta daudzums un tā tiešās izmaksas

\begin{tabular}{||c|c|c|c||}
\hline \hline & $\begin{array}{c}\text { Cik kg } \\
\text { produkta no } \\
1 \text { kg brētliṇu }\end{array}$ & $\begin{array}{c}\text { Jēlu brētliṇu } \\
\text { dala produkta } \\
\text { kalkulācijā }\end{array}$ & $\begin{array}{c}\text { Tiešā pašiz- } \\
\text { maksa (eiro) }\end{array}$ \\
\hline Saldētu brētliṇu eksports & 1.030 & 0.971 & 0.30 \\
\hline Šprotes (no 1 kg brētliṇu) & 0.714 & 1.400 & 1.47 \\
\hline $\begin{array}{c}\text { Brētlinas tomātu mērcēe, } \\
\text { konservi }\end{array}$ & 1.667 & 0.600 & 1.56 \\
\hline
\end{tabular}

\begin{tabular}{||c|c|c|c||}
\hline \hline & $\begin{array}{c}\text { Cik kg } \\
\text { produkta no } \\
\text { 1kg brētliṇu }\end{array}$ & $\begin{array}{c}\text { Jēlu brētliṇu } \\
\text { dala produkta } \\
\text { kalkulācijā }\end{array}$ & $\begin{array}{c}\text { Tiešā pašiz- } \\
\text { maksa (eiro) }\end{array}$ \\
\hline Terīne ar olu & 2.525 & 0.396 & 0.77 \\
\hline Pelmeṇi & 4.779 & 0.209 & 0.62 \\
\hline Pìrāgi & 5.659 & 0.177 & 0.60 \\
\hline Zivju kotletes želejā & 4.820 & 0.207 & 0.50 \\
\hline Zivju pirkstiṇi & 4.940 & 0.202 & 0.83 \\
\hline Zivju makaroni & 10.960 & 0.091 & 0.75 \\
\hline Desa & 6.800 & 0.147 & 0.80 \\
\hline
\end{tabular}

Jāatzīmē, ka, ražojot šprotes no vietējām izejvielām, 1 kilogramā šprotu brētlinu ir vairāk, nekā 1 kg. To rada lielais atkritumu daudzums ražošanā. Šāda ražošana noteikti ir svarīga no tradicionālās zivju pārstrādes un Latvijas vēsturisko produktu saglabāšanas viedokla, taču tā ir pretrunā ar pieejamo izejvielu ilgtspējīgu izmantošanu, jo šie atlikumi nerada nekādus papildu pārtikas produktus.

Nemot vērā pieṇemto lēmumu par produktu sadalijumu atbilstoši saražotajiem apjomiem plānotajā uzṇēmuma sortimentā, kā arī noteiktās iespējamās tirgus cenas, iegūstam, ka 1 kg brētliṇu vidējā cena, pārdodot šo kilogramu kā pārstrukturētus produktus, ir 7,01 eiro. To var uzskatāmi nodemonstrēet diagrammā.

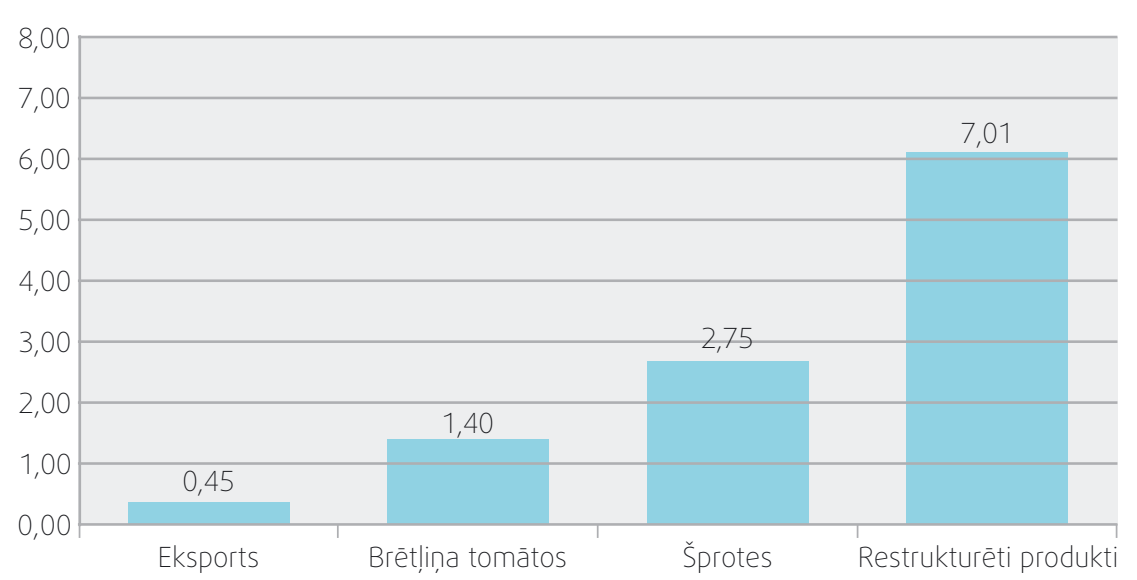

42. attēls. Viena brētliṇu kg eksporta vērtība dažādos produktos 


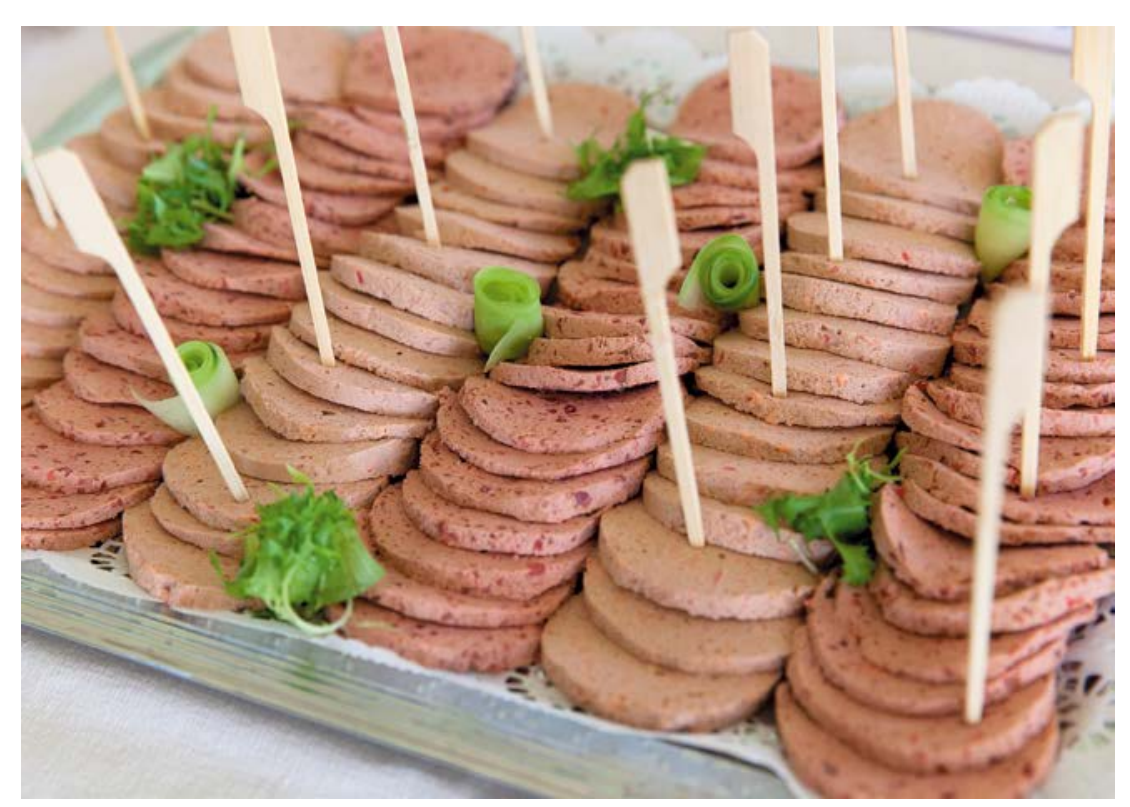

43. attēls. Maltās zivju gạlas izstrādājumi - zivju desas, pasniegšanas piemērs
1. Cleland A.C. Food refrigeration processes: analysis, design, and simulation. Elsevier Applied Science. 1990. 284 pp.

2. Connell J. J. Control of Fish Quality, 4th Edition. Wiley-Blackwell. 1995. 256 pp. 3. Benjamin K. Simpson Ph.D. Food Biochemistry and Food Processing, Second Edition. John Wiley \& Sons, Inc. 2012. 896 pp.

4. George M.P., Tucker B. Seafood Effects of Technology on Nutrition. CRC Press. $384 \mathrm{pp}$

5. Gopakumar K. Textbook of Fish Processing Technology. New DElhi Indian Council Of Agricultural Research. 2002. 491 pp.

6. Pawar P.A., Aachal H. (2013) HACCP in Retail and Food Service Operations. Purwar International Journal of Engineering Science Invention. Volume 2 Issue 10. pp. $50-66$

7. Hall G.M. Fish Processing Technology. Springer Science \& Business Media, 2012. 292 pp

8. Latvijas zivsaimniecibas gadagrāmata 2017, (http://laukutikls.lv/ latvijas-zivsaimniecibas-gadagramata-2017)

9. Mayes T., Mortimore S. Making the Most of HACCP 1st Edition. Woodhead Publishing. 2001. 304 pp

10. Chan E.C.S., Pelczar M.J., Krieg N.R. Microbiology (Fifth Edition). McGraw-Hill Education, 1998. 900 pp.

11. Paré J.R.J. Bélanger J.M.R. Instrumental Methods in Food Analysis, Volume 18, 1st Edition. Elsevier Science. 1997. 486 pp.

12. Paul J. Marine Microbiology, Volume 30, 1st Edition. Academic Press. 2001. $666 \mathrm{pp}$.

13. Regenstein J.M., Regenstein C.E. Introduction to Fish Technology. Springer US. 1995. 270 PP.

14. Sen D.P. Advances in Fish Processing Technology. Allied Publishers, 2005. $848 \mathrm{pp}$.

15. Venugopal V. Seafood Processing. Adding Value Through Quick Freezing, Retortable Packaging and Cook-Chilling, 1st Edition. CRC Press. 2005. 504 pp.

16. Omachonu V.K. Ross J.E. Principles of Total Quality. 3rd Edition. CRC Press. 2004. 512 pp.

17. Андрусенко П.И. Малоотходная и безотходная технология при обработке рыбы. Агропромиздат, 1988. 112 с.

18. Кудерский Л.А. Рыболовство и рыборазведение в Балтийском море. // Тез. докл. VI Международного экологического форума День Балтийского моря. СПб.: Издательский дом Герда, 2005, 242-243 с. 


\section{STRUKTURĒTAS ZIVJU MASAS UN TO PRODUKTU RAŽOŠANAS ROKASGRĀMATA}

Zivju pãrstrādes nozarē nepilnīgas izejvielu izmantošanas problēma ir īpaši aktuāla, jo tā veido ievērojami lielu procentuālo daḷu no zivju pārstrādes ražošanas procesa. Pievienotā vērtība, kas tiks iegūta risinot šo problēmu, ir pievilcīga alternatīva ne tikai tāpēc, ka rada papildu ekonomiskus stimulus ražotājam, bet arī atbilst zilās ekonomikas principiem un nodrošina ilgtspēju un atbildīgu attieksmi pret resursiem.

Rokasgrāmatas saturā tiek aprakstīti uzturā izmantojamās brētliṇu maltās galas un to atbilstošu galaproduktu ražošanas tehnoloǵiskie procesi un tehnoloǵiskās īpašỉbas. Tā pat tiek izvērtēts ekonomiskais pamatojums brētliṇu maltās galas produktu ražošanai. Rokasgrāmata paredzēta pārtikas nozares bakalaura, maǵistrantūras, doktorantūras programmu studentiem, zivju pārstrādes nozares zinātniekiem, ka arī nozares speciālistiem, pārtikas tehnologiem.
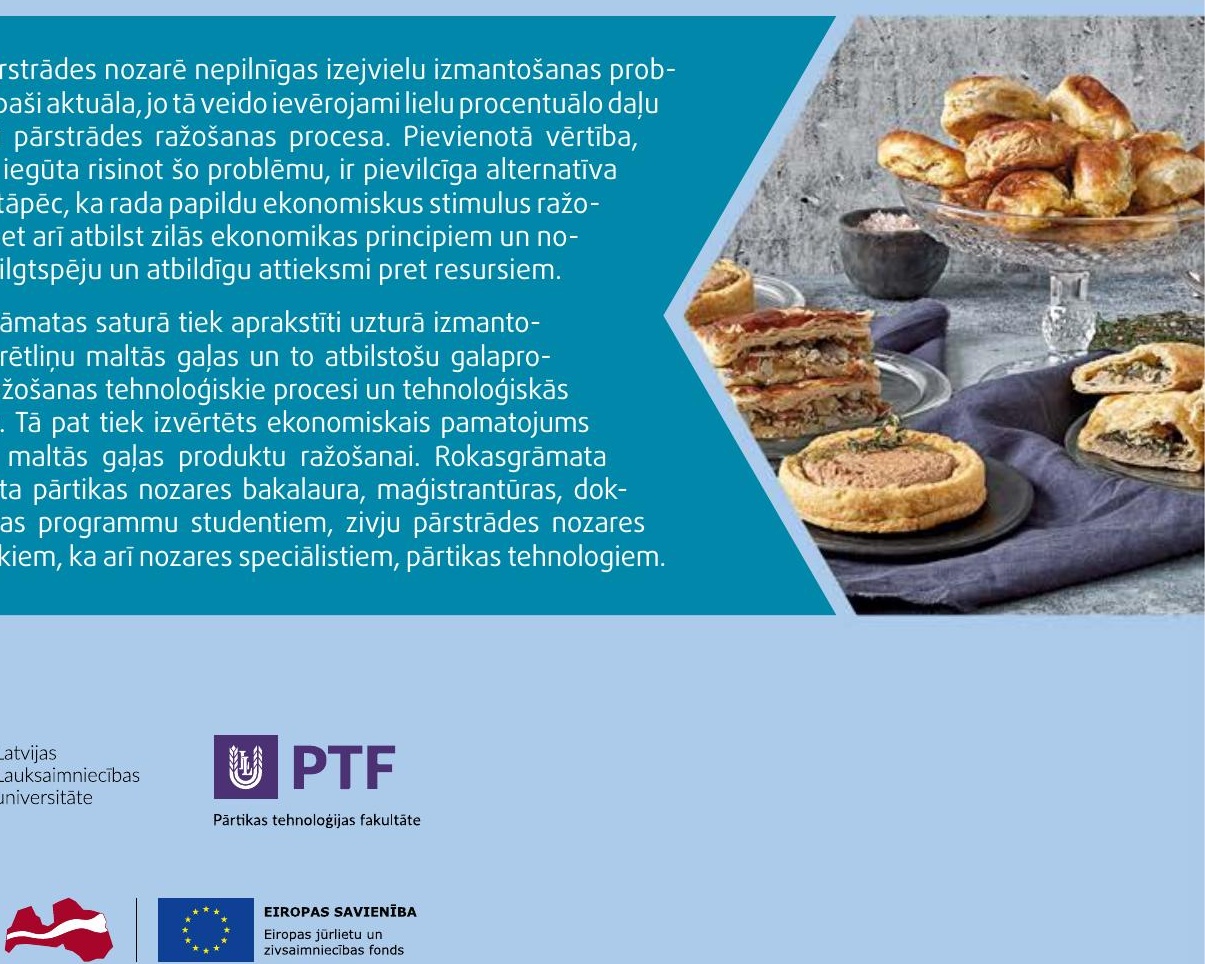

EIROPAS SAVIENĪBA

Eiropas jūrlietu un zivsaimniecibas fonds

Atbalsta Zemkopības ministrija un Lauku atbalsta dienests

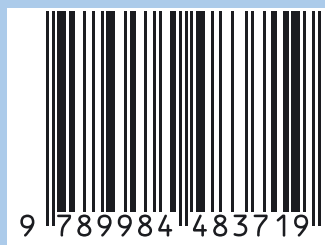

